\title{
Community structure and interaction webs of flower-visiting and cavity-nesting insects along an experimental plant diversity gradient
}

\author{
Dissertation \\ zur Erlangung des Doktorgrades \\ der Fakultät für Agrarwissenschaften \\ der Georg-August-Universität Göttingen
}

\author{
vorgelegt von \\ Anne Ebeling \\ geboren in Cottbus
}

Göttingen, Mai 2008 
D 7

1. Referent: Prof. Dr. Teja Tscharntke

2. Korreferent: Prof. Dr. Wolfgang W. Weisser

Tag der Disputation: 3. Juli 2008 


\section{CONTENTS}

1 COMMUNITY STRUCTURE AND INTERACTION WEBS OF FLOWER-VISITING AND CAVITY-NESTING INSECTS ALONG AN EXPERIMENTAL PLANT DIVERSITY GRADIENT - GENERAL INTRODUCTION, RESULTS AND CONLUSIONS

General introduction

Biodiversity

Plant diversity effects on invasion success and fitness of plants

Plant diversity effects on pollinators and cavity-nesting hymenoptera 6

The study of biodiversity

The Jena-Experiment

Outline of the thesis

Results and conclusions

Invasion success and performance of Centaurea jacea 11

Pollinator communities and plant-pollinator interactions 11

Cavity-nesting bees, wasps and their natural enemies $\quad 12$

$\begin{array}{ll}\text { References } & 14\end{array}$

2 PLANT DIVERSITY EFFECTS ON INVASIVENESS, PLANT FITNESS AND 18 HERBIVORY IN THE COMMON KNAPWEED, CENTAUREA JACEA

Abstract

Introduction

Materials and methods $\quad 20$

Results $\quad 23$

Discussion $\quad 31$

References $\quad 35$

3 HOW DOES PLANT SPECIES RICHNESS AFFECT POLLINATOR RICHNESS 40 AND TEMPORAL STABILITY OF FLOWER VISITS?

$\begin{array}{lr}\text { Abstract } & 41 \\ \text { Introduction } & 41 \\ \text { Materials and methods } & 43 \\ \text { Results } & 45 \\ \text { Discussion } & 49 \\ \text { References } & 52\end{array}$ 
4 PLANT DIVERSITY INCREASES FLORAL SPECIALIZATION IN PLANTPOLLINATOR INTERACTION WEBS

Abstract

Introduction

Materials and methods

Results

Discussion

66

References

5 EXPERIMENTAL SMALL-SCALE CHANGES IN PLANT DIVERSITY AFFECT NESTING BEES AND WASPS AND THEIR PARASITOIDS

Abstract

Introduction

Materials and methods

Results

Discussion

References

SUMMARY

DANKSAGUNG 


\section{CHAPTER 1}

COMMUNITY STRUCTURE AND INTERACTION WEBS OF FLOWER-VISITING AND CAVITY-NESTING INSECTS ALONG AN EXPERIMENTAL PLANT DIVERSITY GRADIENT

GENERAL INTRODUCTION, RESULTS AND CONCLUSIONS

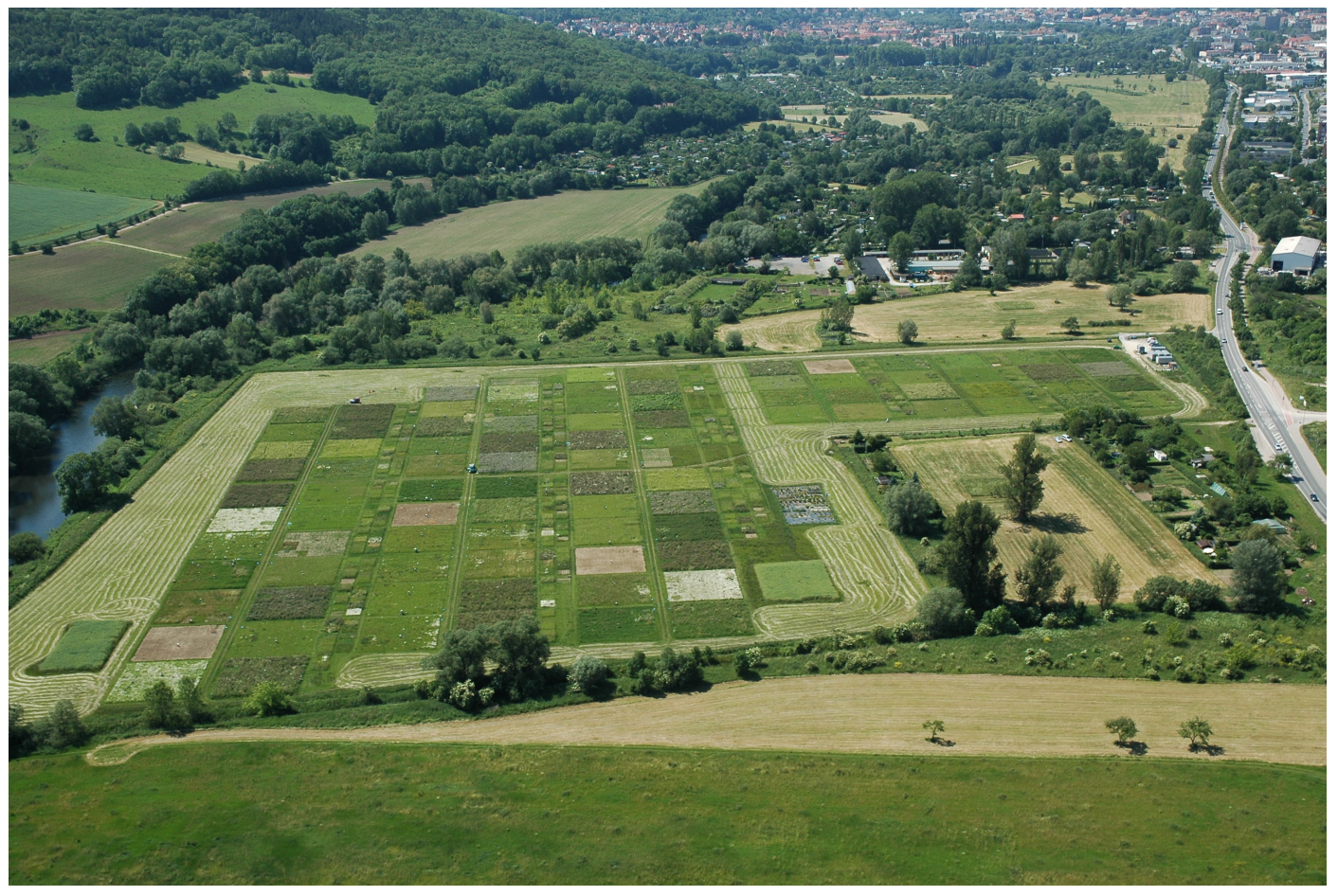




\section{General Introduction}

\section{Biodiversity}

The number of species on earth is estimated to be 13.5 Million (Hawksworth and Kalin-Arroyo 1995). This great diversity is endangered (Sala et al. 2000), but in contrast to earlier mass extinctions, which aroused from climatic changes or sea-level fluctuations, the current change is mainly caused by human activities (Robinson and Sutherland 2002, Foley et al. 2005, Biesmeijer et al. 2006). Natural extinctions in former times were mostly replaced by speciation and there was a steady state of extinction and speciation over a long time (Rosenzweig 2001). Thomas et al. 2004 found extinction rates of butterflies, birds, and plants in the UK of around 3.4\% during the last 40 years, which highlights that life is not able to rebound from human induced species loss (Rosenzweig 2001). Reasons for the great impact of humans on species loss are for example direct habitat disruption, habitat fragmentation, agricultural intensification, degradation and climatic changes (Sala et al. 2000, Tscharntke 2002, Gaston and Spicer 2004; Tscharntke et al. 2005). Humans strongly depend on ecosystem services such as primary production, crop pollination, or pest control and therefore understanding the consequences of species loss for biotic interactions and associated ecosystem services has become a major focus (Montoya et al. 2003, Kremen 2005, Tscharntke et al. 2005, Balvanera et al. 2006). In this thesis we measured plant fitness, insect diversity and density and several connected ecosystem services to detect how plant diversity changes these groups and their provided services.

\section{Plant diversity effects on invasion success and fitness of plants}

Based on Elton's diversity-stability hypothesis (Elton 1958) several experiments tested and confirmed the suggested positive effect of plant species richness on invasion-resistance of a community (e.g. Knops et al. 1999, Naeem et al. 2000, Hector et al. 2001 and Kennedy et al. 2002). However, other studies either intentionally tested or unexpectedly found a great influence of plant functional identity of the resident community (Turnbull et al. 2005, Mwangi et al. 2007). For example, particular functional groups such as grasses and legumes seem to exhibit negative and positive effects on invader performance respectively (Fargione et al. 2003, Scherber et al. 2006, Mwangi et al. 2006). It also became clear that, independent of functional group identity; particular species have the ability to operate as strong barriers to invasion by 'foreign' species. Hence, their presence and abundance within the community invaded plays a major role for the invasion process (Crawley et al. 1999, Dukes 2002, van Ruijven et al. 2003). Generalisations on the role of diversity for invasion-resistance are difficult, and invader success may be different at different points in time (Prieur-Richard and Lavorel 2000, White and Shurin 2007). However, most experiments on invasion 
resistance in relation to components of diversity in grassland ecosystems were undertaken as 'seed addition' or 'weeding' experiments and investigated but a short period of the establishment process, often as result of experimental, organisational or financial constraints.

By introducing seedlings (phytometer) of Centaurea jacea into the experimental plots with changing plant species richness we studied invasion success over three years after its setup and establishment of the survived phytometers.

\section{Plant diversity effects on pollinators and cavity-nesting hymenoptera}

Flower-visitors play a major role in the reproduction success of most plant species (Burd 1994; Fontaine et al. 2006, Klein et al. 2007), with solitary and social wild bees being recognized as one of the most important pollinators in Central Europe (Corbet et al. 1991). In Germany 547 bee species are mapped, of which $52 \%$ belong to the red list (www.bfn.de/). As a loss in plant species richness can lead to a parallel decline of their associated pollinators (Biesmeijer et al. 2006), it is important to understand plant-pollinator community interactions for the conservation of pollinator diversity.

Additionally to records of flower-visitors in the field, we studied communities of cavity-nesting bees and wasps and interactions with their natural enemies under standardized conditions. Cavity-nesting bees, wasps, and their natural enemies provide a set of interesting ecological functions (Tscharntke et al 1998, Gathmann and Tscharntke 1999). Bees as pollinators for crop plants and wasps as pest predators (by provisioning their nests with e.g. Lepidoptera larvae or aphids) are important functional guilds of terrestrial ecosystems (LaSalle and Gauld 1993). Additionally, solitary bees and wasps were found to be suitable as an indicator of biodiversity (Tscharntke et al. 1998). Trap nests consists of a plastic tube filled with reed internodes of Phragmites australis (Tscharntke et al. 1998). Within the internodes adult solitary bees and wasps build their nests with several brood cells, each containing one larvae and its food. Natural enemies of those species feed on the larvae (parasitism) or their food (cleptoparasitism).

\section{The study of biodiversity}

There are two possibilities to study the effects of biodiversity on ecosystem processes: (1) real world studies along natural plant diversity gradients, and (2) biodiversity experiments with manipulated plant species richness. One advantage of real world studies is the long establishment of the natural communities (e.g. plant communities), but these studies cannot control for additional influences occurring in natural ecosystems, such as differences in plant composition and floral diversity (Schmid and Hector 2004). Here, differences in plant species richness among plots are mostly the result of differences in habitat variables such as land-use intensity (intensity of habitat management), 
making it difficult to attribute changes in e.g. plant-pollinator interactions directly to differences in plant diversity. Management often reduces plant species richness, but also entails mechanical disturbances as well as the availability of nutrients and water. For example, fertilization increases flower size, and leads to a higher quality of nectar and pollen (Spaethe et al. 2001, Thompson 2001, Cartar 2004). In turn, e.g. pollinators are affected by these changes of the quality of floral resources (Cartar 2004), showing the difficulties disentangling the effects of plant species richness and other habitat variables to explain patterns in pollinator communities.

In biodiversity experiments, species richness is manipulated as independent variable and the community composition is randomly selected out of a given species pool. Advantages are the existence of extremes we rarely find in real world ecosystems (as monocultures) and the possibility to study species richness per se.

There is a long controversial debate about the pro and contra of biodiversity experiments (Leps 2004, Schmid and Hector 2004) but the enriching results coming from biodiversity experiments during the last 15 years (Balvanera et al. 2006, Cardinale et al. 2006) verified their great contribution to the understanding of biodiversity patterns and processes.

In comparison to former biodiversity experiments the Jena-Experiment mainly focuses on element cycling and trophic interactions, which accounts for the great size of the single plots $\left(400 \mathrm{~m}^{2}\right.$ in comparison e.g. to BIODEPTH with $4 \mathrm{~m}^{2}$ plots). Therefore, several measurements can be conducted simultaneously and also higher trophic levels for insects have already been studied over a long period (6 years to date).

\section{The Jena-Experiment}

The study site of the Jena-Experiment was established in May 2002 and is located at the floodplain of the river Saale (Thuringia, Germany, 50 ${ }^{\circ} 55^{\prime} \mathrm{N}, 1^{\circ} 35^{\prime} \mathrm{E} ; 130 \mathrm{~m}$ above sea level). It was used as an arable field before the sowing of the experimental species.

The plant communities were sown in 82 large plots of $20 \times 20 \mathrm{~m}$ with a gradient of species richness $(1,2,4,8,16$ and 60) per plot, while plant species composition was randomly selected out of a species pool of 60 common grassland species (Arrhenaterion-Community, Table 1). Plant species were divided into four functional groups taking morphological (e.g. growth form, plant height, leaf size, depth of root system), phenological (e.g. life cycle, seasonality of foliage, flowering period) and physiological plant traits (capacity of $\mathrm{N}$-fixation) into account. All traits were included into multivariate analyses (Roscher et al. 2004) resulting in the four groups grasses, small herbs, tall herbs and legumes. Finally, all possible combinations of number of plant species* number of functional groups were realized (Figure 1). Apart from the 16- and 60- species mixtures each 
diversity level is replicated 16 times (= 16 plots) without identical species allocation. 16- and 60species mixtures are replicated 14 and four times respectively. The 82 plots are systematically divided into four blocks (randomized complete block design), taking abiotic gradients (distance to the river Saale) into account. Each block is composed of about 22 plots on which the same numbers of replicates for each diversity level are implemented. To maintain the sown species diversity level we weeded all plots regularly twice per year in April and July and used herbicide where possible (Figure 2). Plots are mown twice a year and biomass is removed from the site.

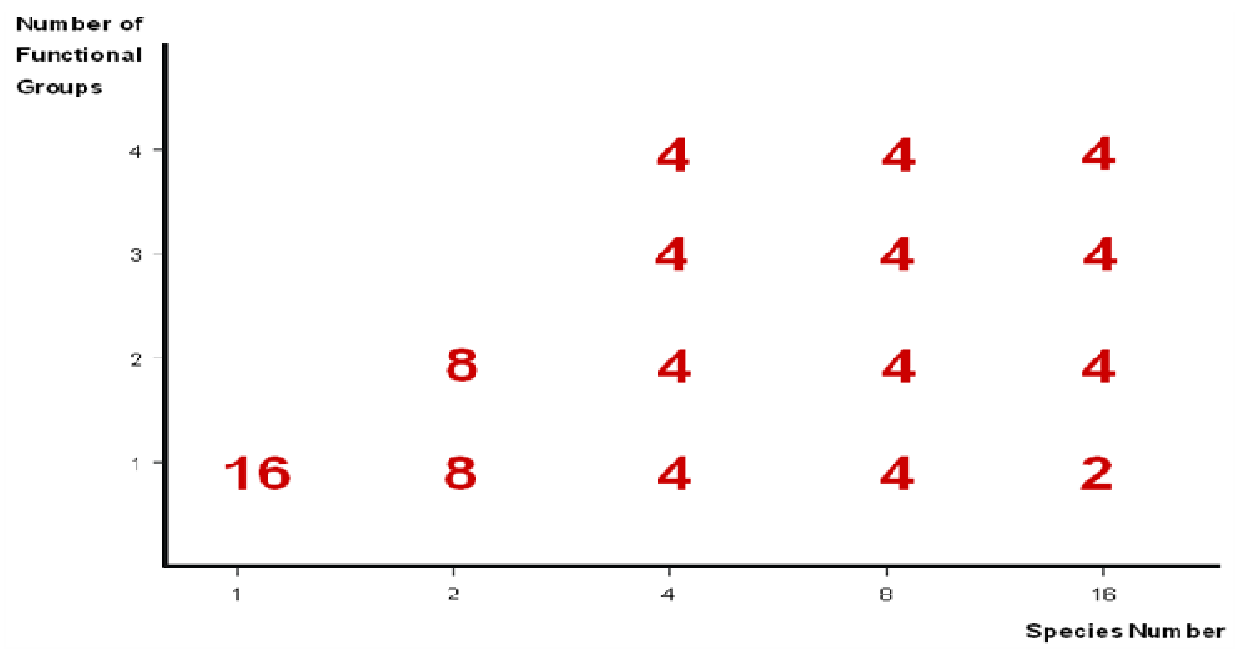

Figure 1: Overview of all posssible combinations between plant species richness and functional group richness (Graph: J. Schumacher) 
Table 1: Species list of the 60 species containing to the species pool of the Jena-Experiment (belonging to the Molinio-Arrhenatheretea class)

\begin{tabular}{|c|c|c|}
\hline Functional group & Species & Common German name \\
\hline \multirow{16}{*}{$\begin{array}{l}\text { Grasses } \\
(16 \text { species })\end{array}$} & Alopecurus pratensis & Wiesen-Fuchsschwanz \\
\hline & Anthoxanthum odoratum & Gewöhnliches Ruchgras \\
\hline & Arrhenatherum elatius & Glatthafer \\
\hline & Avenula pubescens & Flaumiger Wiesenhafer \\
\hline & Bromus erectus & Aufrechte Tespe \\
\hline & Bromus hordeaceus & Weiche Trespe \\
\hline & Cynosurus cristatus & Wiesen-Kammgras \\
\hline & Dactylis glomerata & Wiesen-Knäuelgras \\
\hline & Festuca pratensis & Wiesen-Schwingel \\
\hline & Festuca rubra & Gewöhnlicher Rot-Schwingel \\
\hline & Holcus lanatus & Wolliges Honiggras \\
\hline & Luzula campestris & Feld-Hainsimse \\
\hline & Phleum pratense & Wiesen-Lieschgras \\
\hline & Poa pratensis & Gewöhnliches Wiesen-Rispengras \\
\hline & Poa trivialis & Gewöhnliches Rispengras \\
\hline & Trisetum flavescens & Wiesen-Goldhafer \\
\hline \multirow{12}{*}{$\begin{array}{l}\text { Small herbs } \\
\text { (12 species) }\end{array}$} & Ajuga reptans & Kriechender Günsel \\
\hline & Bellis perennis & Gänseblümchen \\
\hline & Glechoma hederacea & Gundermann \\
\hline & Leontodon autumnalis & Herbst-Löwenzahn \\
\hline & Leontodon hispidus & Rauher Löwenzahn \\
\hline & Plantago lanceolata & Spitzwegerich \\
\hline & Plantago media & Mittlerer Wegerich \\
\hline & Primula veris & Wiesen-Schlüsselblume \\
\hline & Prunella vulgaris & Kleine Braunelle \\
\hline & Ranunculus repens & Kriechender Hahnenfuß \\
\hline & Taraxacum officinale & Wiesen-Löwenzahn \\
\hline & Veronica chamaedrys & Gamander-Ehrenpreis \\
\hline \multirow{20}{*}{$\begin{array}{l}\text { Tall herbs } \\
\text { (20 species) }\end{array}$} & Achillea millefolium & Gewöhnliche Wiesen-Schafgarbe \\
\hline & Anthriscus sylvestris & Wiesen-Kerbel \\
\hline & Campanula patula & Wiesen-Glockenblume \\
\hline & Cardamine pratensis & Wiesen-Schaumkraut \\
\hline & Carum carvi & Wiesen-Kümmel \\
\hline & Centaurea jacea & Wiesen-Flockenblume \\
\hline & Cirsium oleraceum & Kohl-Kratzdistel \\
\hline & Crepis biennis & Wiesen-Pippau \\
\hline & Daucus carota & Wilde Möhre \\
\hline & Galium mollugo & Wiesen-Labkraut \\
\hline & Geranium pratense & Wiesen-Storchschnabel \\
\hline & Heracleum sphondylium & Wiesen-Bärenklau \\
\hline & Knautia arvensis & Wiesen-Witwenblume \\
\hline & Leucanthemum vulgare & Gewöhnliche Margerite \\
\hline & Pastinaca sativa & Pastinak \\
\hline & Pimpinella major & Große Bibernelle \\
\hline & Ranunculus acris & Scharfer Hahnenfuß \\
\hline & Rumex acetosa & Großer Sauerampfer \\
\hline & Sanguisorba officinalis & Großer Wiesenknopf \\
\hline & Tragopogon pratensis & Wiesen-Bocksbart \\
\hline \multirow{12}{*}{$\begin{array}{l}\text { Legumes } \\
\text { (12 species) }\end{array}$} & Lathyrus pratensis & Wiesen-Platterbse \\
\hline & Lotus corniculatus & Gewöhnlicher Hornklee \\
\hline & Medicago lupulina & Hopfenklee \\
\hline & Medicago varia & Luzerne \\
\hline & Onobrychis viciifolia & Esparsette \\
\hline & Trifolium campestre & Feld-Klee \\
\hline & Trifolium dubium & Gewöhnlicher Kleiner Klee \\
\hline & Trifolium hybridum & Schweden-Klee \\
\hline & Trifolium pratense & Wiesen-Klee \\
\hline & Trifolium repens & Weiß-Klee \\
\hline & Vicia cracca & Gewöhnliche Vogel-Wicke \\
\hline & Vicia sepium & Zaun-Wicke \\
\hline
\end{tabular}




\section{Outline of the thesis}

The major aim of this thesis was to better understand the impact of plant species richness on, plant invasion success, insect diversity and higher trophic-level interactions. Thereby we addressed the following questions:

1. How does plant species and functional group richness affect invasion success and performance of a transplanted phytometer species?

2. Is there a relationship between plant species richness and pollinator diversity and density?

3. How does plant species richness affect the temporal stability of pollinator visitation?

4. How does plant species richness change the structure and the diversity of plant-pollinator interactions?

5. How does plant species richness (small scale effects) and surrounding habitats (large scale effects) affect the diversity of bees, wasps and their natural enemies colonizing standardized nesting resources?

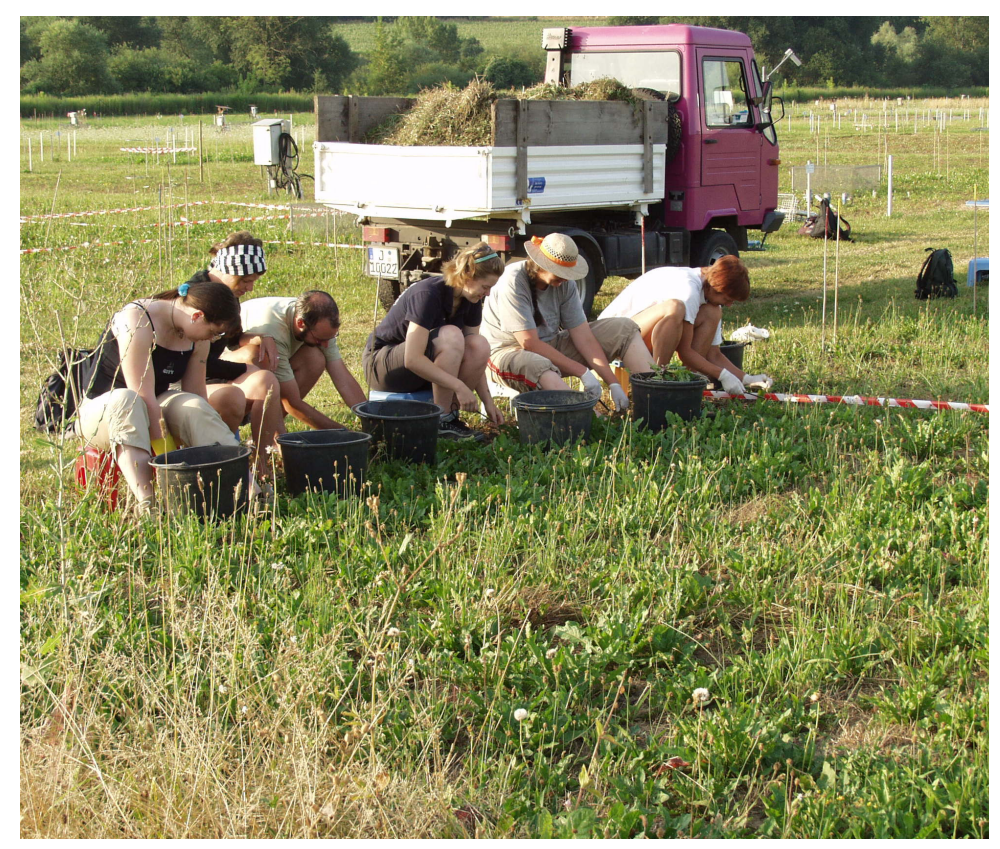

Figure 2: Weeding campaign on the study site to maintain the sown plant species richness (Photo: A. Weigelt) 


\section{Results and Conclusions}

\section{Invasion success and performance of Centaurea jacea}

Mean survival of Centaurea jacea amounted to 72.8\% in spring 2006 and decreased further on $49.0 \%$ (spring 2008) of originally implanted individuals. Survival was negatively influenced by community biomass and the presence of legumes. Plant performance traits as plant dry weight, plant height or the number of flower heads increased with years after transplantation and were negatively influenced by community biomass and plant species richness. The number of flower heads additionally decreased with increasing plant functional group richness. Herbivory in both years was surprisingly low with averaged $4.4 \%$ and $5.3 \%$ leaf area damage and was positively influenced by community biomass, but not plant species richness.

In conclusion it was proven that parameters influencing survival and performance of an invader species depend on the stage of the invasion process (effects get stronger with years after transplanting). In comparison with former our findings underline that both plant species richness and plant functional identity can have a great impact on survival and performance of an invader species and that invader response is idiosyncratic.

\section{Pollinator communities and plant-pollinator interactions}

Analyzing the temporal variability in the frequency of pollinator visits (CV) across all observational periods per plot, there was a significant decline in the variability with increasing floral diversity and with pollinator species richness. Pollinator species richness was strongly affected by two variables: the number of flowering plant species and the blossom cover. With increasing floral diversity and blossom cover we found higher numbers of pollinator species. Species richness of bumble bees and solitary bees was related positively solely with floral diversity. The overall frequency of pollinator visits again was positively correlated with floral diversity and with blossom cover. Additionally the frequency of pollinator visits was enhanced by the presence of attractive plant species. The frequency of bumble bee and honey bee visits followed the same pattern, whereas the frequency of solitary bee visits was positively influenced only by floral diversity and the presence of attractive plant species.

Network measurements gave more detailed information about the influence of plant species richness (here floral diversity) on the structure of plant-pollinator interactions and therefore an idea of changes in their ecosystem functioning (e.g. pollination success). Linkage density (number of trophic links/ total number of species) increased and network connectance (number of possible trophic links/ number of realized trophic links) decreased with increasing number of flowering plant 
species. We found neither changes of specialization on the network level (degree of network organization), nor on the guild level (plant specialization, pollinator specialization) with increasing floral diversity, but analyzing the different pollinator guilds there was evidence for strong differences in their resource specialization. Bumble bee specialization was not related to floral resources, contrastingly, honeybees tended to increase their resource specialization with increasing floral diversity, and this pattern was even stronger for solitary bees.

In conclusion high floral diversity enhanced overall pollinator species richness and caused higher dynamic stability in flower visitation. High blossom cover of plants enhanced social bee species, which are known to exploit mass resources, but not solitary species, which are more structured by the heterogeneity of high plant species richness. Floral diversity also changed the structure and resource specialization in the pollinator communities. The higher linkage density in more diverse floral displays may result in enhanced network stability, whereas enhanced specialization of solitary and honeybee pollinators should result in improved pollination success. Therefore rich plant communities (with diverse floral displays) and the availability of flowers over time appeared to be important in grasslands to serve as foraging resources for highly-diverse, more specialized pollinator communities and a high pollinator visitation rate that can be expected to enhance reproduction success of many plant species.

\section{Cavity- nesting bees, wasps and their natural enemies}

Species richness of bees and wasps was neither affected by plant species richness nor floral diversity (the number of plants in bloom), and only increased with increasing number of bee brood cells. The brood cell abundance of bees and wasps in turn was significantly positively related to the floral diversity. Additionally the brood cell abundance of wasps was influenced by the surrounding landscape (highest in plots directly connected to the river and the lowest in plots inside the experimental field site or located at the street). High parasitoid species richness, attacking bees and wasps, for both guilds was mainly positively related to brood cell abundance and their species richness. Further parasitoid diversity of both, bees and wasps, increased their parasitism rate, whereas species richness of hosts (bees and wasps) decreased parasitism rate (consumption by parasitoids). Wasp parasitoid diversity additionally decreased with increasing distance to the river.

In summary we found that diverse floral displays attracted higher densities of pollinators (bees) and predators (wasps), whereas higher densities as well increased their species richness. The more diverse host communities we found with increasing floral diversity attracted a higher number of parasitoid species, which increased their function (parasitism). But contrastingly, increasing host 
diversity could limit parasitism; hence species rich plant communities containing cavity-nest communities might be more resistance against consumption. In conclusion, grasslands with high numbers of plant species enhance the diversity and abundance of cavity-nesting bees and wasps and their associated ecosystem services (e.g. pollination, pest control), underlining the need to conserve diverse grasslands.

\section{References}

Balvanera, P., Pfisterer, A. B., Buchmann, N., He, J. S., Nakashizuka, T., Raffaelli, D. and Schmid, B. 2006. Quantifying the evidence for biodiversity effects on ecosystem functioning and services. - Ecology Letters 9: 1146-1156.

Biesmeijer, J. C., Roberts, S. P. M., Reemer, M., Ohlemuller, R., Edwards, M., Peeters, T., Schaffers, A. P., Potts, S. G., Kleukers, R., Thomas, C. D., Settele, J. and Kunin, W. E. 2006. Parallel declines in pollinators and insect-pollinated plants in Britain and the Netherlands. Science 313: 351-354.

Burd, M. 1994. Bateman principle and plant reproduction - the role of pollen limitation in fruit and seed set. - Botanical Review 60: 83-139.

Cardinale, B. J., Srivastava, D. S., Duffy, J. E., Wright, J. P., Downing, A. L., Sankaran, M. and Jouseau, C. 2006. Effects of biodiversity on the functioning of trophic groups and ecosystems. Nature 443: 989-992.

Cartar, R. V. 2004. Resource tracking by bumble bees: Responses to plant-level differences in quality. - Ecology 85: 2764-2771.

Corbet, S.A., Williams, I.H. \& Osborne J.L. 1991. Bees and the pollination of crops and wild flowers in the European Community. Bee World 72: 57-59.

Crawley, M. J., Brown, S. L., Heard, M. S. and Edwards, G. R. 1999. Invasion-resistance in experimental grassland communities: species richness or species identity? - Ecology Letters 2: 140-148.

Elton, C.S. 1958. Ecology of invasions by animals and plants. Chapman \& Hall.

Fargione, J., Brown, C. S. and Tilman, D. 2004. Community assembly and invasion: An experimental test of neutral versus niche processes (vol 100, pg 8916, 2003). - Proceedings of the National Academy of Sciences of the United States of America 101: 414-414.

Foley, J. A., DeFries, R., Asner, G. P., Barford, C., Bonan, G., Carpenter, S. R., Chapin, F. S., Coe, M. T., Daily, G. C., Gibbs, H. K., Helkowski, J. H., Holloway, T., Howard, E. A., Kucharik, C. J., Monfreda, C., Patz, J. A., Prentice, I. C., Ramankutty, N. and Snyder, P. K. 2005. Global consequences of land use. - Science 309: 570-574. 
Fontaine, C., Dajoz, I., Meriguet, J. and Loreau, M. 2006. Functional diversity of plant-pollinator interaction webs enhances the persistance of plant communities. - PLoS Biol 4.

Gathmann, A. and Tscharntke, T. 1999. Landschafts-Bewertung mit Bienen und Wespen in Nisthilfen: Artenspektrum, Interaktionen und Bestimmungsschlüssel. - Naturschutz und Lamdschaftspflege Baden-Württemberg 73: 277-305.

Hawksworth, D.L. and Kalin-Arroyo, M.T. 1995. Magnitude and distribution of biodiversity. In: Global biodiversity assessment (ed. Heywood, V.H.). - Cambridge University Press, Cambridge.

Hector, A., Dobson, K., Minns, A., Bazeley-White, E. and Lawton, J. H. 2001. Community diversity and invasion resistance: An experimental test in a grassland ecosystem and a review of comparable studies. - Ecological Research 16: 819-831.

Kennedy, T. A., Naeem, S., Howe, K. M., Knops, J. M. H., Tilman, D. and Reich, P. 2002. Biodiversity as a barrier to ecological invasion. - Nature 417: 636-638.

Klein, A. M., Vaissiere, B. E., Cane, J. H., Steffan-Dewenter, I., Cunningham, S. A., Kremen, C. and Tscharntke, T. 2007. Importance of pollinators in changing landscapes for world crops. Proceedings of the Royal Society B-Biological Sciences 274: 303-313.

Knops, J. M. H., Tilman, D., Haddad, N. M., Naeem, S., Mitchell, C. E., Haarstad, J., Ritchie, M. E., Howe, K. M., Reich, P. B., Siemann, E. and Groth, J. 1999. Effects of plant species richness on invasion dynamics, disease outbreaks, insect abundances and diversity. - Ecology Letters 2: 286293.

Kremen, C. 2005. Managing ecosystem services: what do we need to know about their ecology? Ecology Letters 8: 468-479.

LaSalle, J. and Gould, I.D. 1993. Hymenoptera: their diversity, and their impact on the diversity of other organisms in: J. LaSalle and Gould, I.D (ed) Hymenoptera and Biodiversity.- CAB International, Wallingford, U.K., pp 1-26.

Leps, J. 2004. What do the biodiversity experiments tell us about consequences of plant species loss in the real world? - Basic and Applied Ecology 5: 529-534.

Montoya, J. M., Rodriguez, M. A. and Hawkins, B. A. 2003. Food web complexity and higher-level ecosystem services. - Ecology Letters 6: 587-593.

Mwangi, P. N., Schmitz, M., Scherber, C., Roscher, C., Schumacher, J., Scherer-Lorenzen, M., Weisser, W. W. and Schmid, B. 2007. Niche pre-emption increases with species richness in experimental plant communities. - Journal of Ecology 95: 65-78.

Naeem, S., Knops, J. M. H., Tilman, D., Howe, K. M., Kennedy, T. and Gale, S. 2000. Plant diversity increases resistance to invasion in the absence of covarying extrinsic factors. - Oikos 91: 97-108. 
Prieur-Richard, A. H. and Lavorel, S. 2000. Invasions: the perspective of diverse plant communities. - Austral Ecology 25: 1-7.

Robinson, R. A. and Sutherland, W. J. 2002. Post-war changes in arable farming and biodiversity in Great Britain. - Journal of Applied Ecology 39: 157-176.

Roscher, C., Schumacher, J., Baade, J., Wilcke, W., Gleixner, G., Weisser, W. W., Schmid, B. and Schulze, E. D. 2004. The role of biodiversity for element cycling and trophic interactions: an experimental approach in a grassland community. - Basic and Applied Ecology 5: 107-121.

Rosenzweig, M. L. 2001. Loss of speciation rate will impoverish future diversity. - Proceedings of the National Academy of Sciences of the United States of America 98: 5404-5410.

Sala, O. E., Chapin, F. S., Armesto, J. J., Berlow, E., Bloomfield, J., Dirzo, R., Huber-Sanwald, E., Huenneke, L. F., Jackson, R. B., Kinzig, A., Leemans, R., Lodge, D. M., Mooney, H. A., Oesterheld, M., Poff, N. L., Sykes, M. T., Walker, B. H., Walker, M. and Wall, D. H. 2000. Biodiversity - Global biodiversity scenarios for the year 2100. - Science 287: 1770-1774.

Scherber, C., Milcu, A., Partsch, S., Scheu, S. and Weisser, W. W. 2006. The effects of plant diversity and insect herbivory on performance of individual plant species in experimental grassland. - Journal of Ecology 94: 922-931.

Schmid, B. and Hector, A. 2004. The value of biodiversity experiments. - Basic and Applied Ecology 5: 535-542.

Spaethe, J., Tautz, J. and Chittka, L. 2001. Visual constraints in foraging bumblebees: Flower size and color affect search time and flight behavior. - Proceedings of the National Academy of Sciences of the United States of America 98: 3898-3903.

Thomas, C. D., Cameron, A., Green, R. E., Bakkenes, M., Beaumont, L. J., Collingham, Y. C., Erasmus, B. F. N., de Siqueira, M. F., Grainger, A., Hannah, L., Hughes, L., Huntley, B., van Jaarsveld, A. S., Midgley, G. F., Miles, L., Ortega-Huerta, M. A., Peterson, A. T., Phillips, O. L. and Williams, S. E. 2004. Extinction risk from climate change. - Nature 427: 145-148.

Thompson, J. D. 2001. How do visitation patterns vary among pollinators in relation to floral display and floral design in a generalist pollination system? - Oecologia 126: 386-394.

Tscharntke, T. 2002. Characteristics of insect populations on habitat fragments: A mini Review. Ecological research 17: 229-239.

Tscharntke, T., Gathmann, A. and Steffan-Dewenter, I. 1998. Bioindication using trap-nesting bees and wasps and their natural enemies: community structure and interactions. - Journal of applied ecology 35: 708-719. 
Tscharntke, T., Klein, A. M., Kruess, A., Steffan-Dewenter, I. and Thies, C. 2005. Landscape perspectives on agricultural intensification and biodiversity - ecosystem service management. Ecology Letters 8: 857-874.

Turnbull, L. A., Rahm, S., Baudois, O., Eichenberger-Glinz, S., Wacker, L. and Schmid, B. 2005. Experimental invasion by legumes reveals non-random assembly rules in grassland communities. - Journal of Ecology 93: 1062-1070.

van Ruijven, J., De Deyn, G. B. and Berendse, F. 2003. Diversity reduces invasibility in experimental plant communities: the role of plant species. - Ecology Letters 6: 910-918. 


\section{CHAPTER 2}

PLANT DIVERSITY EFFECTS ON INVASIVENESS, PLANT FITNESS AND HERBIVORY IN THE COMMON KNAPWEED,

CENTAUREA JACEA

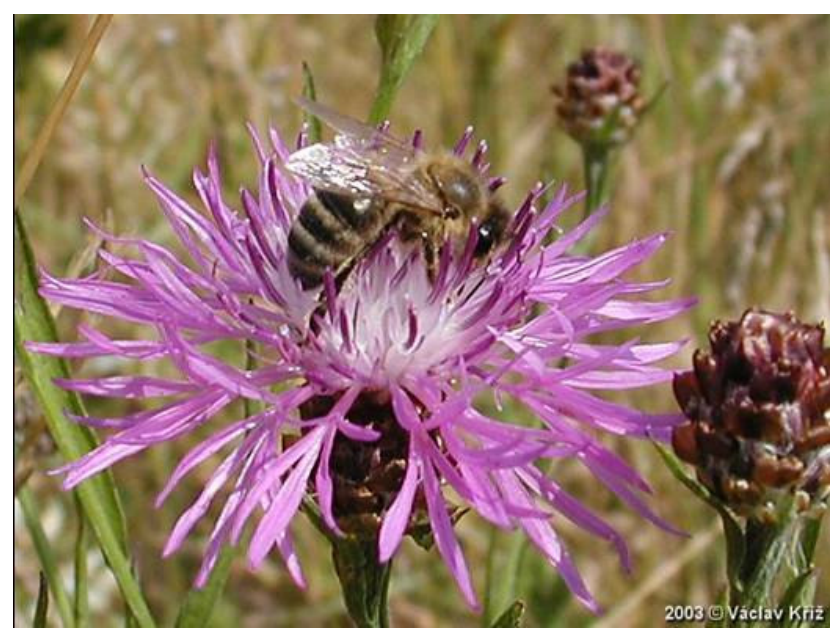




\begin{abstract}
Diverse ecosystems have been predicted to be more resistant to invasion than less diverse systems and a number of experimental studies have supported this view. Many of these studies have been short-term and did not follow the fate of individual plants over time or investigated the trophic interaction of the invading species. We transplanted ten individuals of the perennial Centaurea jacea into 82 experimental grassland plots of manipulated plant species and functional group richness, and treated half of the plants with insecticide. Over three years after transplanting (2005-2008) we counted surviving individuals and during two flowering seasons measured herbivory and plant performance parameters. Herbivory was generally very low at sprayed and unsprayed plants with on average $4.5 \%$ and 5.3\% leaf area removed in 2006 and 2007, respectively, and no differences between the treatments (insecticide and control). The number of surviving plants decreased with increasing plant species and functional group richness mediated through community biomass until averaging $49 \%$ of originally implanted individuals in 2008. $60 \%$ of individuals survived in monocultures compared to $5 \%$ in high diversity mixtures (60 species). Within the first year after transplanting the presence of legumes had an additional strong and negative effect on plant survival. Plant dry weight, plant height, and the number of flower heads decreased with increasing plant species richness; only in the second year after transplantation an additional negative effect of legume presence on transplant performance (plant dry weight) was found. Our findings underline that both plant species richness and plant functional identity can have significant effects on survival and performance of an invader species and that invader response is idiosyncratic.
\end{abstract}

\title{
Introduction
}

The establishment of new members of an ecological community is governed by interspecific actions between the hopeful immigrant and resident species and in many cases the most prominent interaction is interspecific competition. One of the oldest ecological hypothesis on the establishment success of immigrants was phrased in the context of invasion biology and predicts that more diverse communities are more resistant against invasion, because the available "niche space" is reduced in more diverse communities (Elton 1958). For grassland ecosystems, a number of studies have shown that the chance of establishment of newly arriving plants in grassland communities decreases with increasing plant diversity (e.g. Burke and Grime 1996, Tilman 1997, Crawley et al. 1999, Hector et al. 2001, Kennedy et al. 2002, Fargione et al. 2003, van Ruijven et al. 2003, Fargione and Tilman 2005). However, there are also examples of where plant species richness has no effect on invasion (Scherber et al. 2006) or where the presence of particular plant species (Crawley et al. 1999, Dukes 2002, van Ruijven et al. 2003) or plant functional groups (Fargione et al. 2003, Mwangi et al. 2007) are more important in limiting invader success than diversity. In the case of functional groups, 
invading plant species are often more limited by species of the same functional group than by species from other functional groups (Fargione et al. 2003, Turnbull et al. 2005, Mwangi et al. 2007; but see Prieur-Richard et al. 2002). Independent of the invading species, the fate of invaders is often affected negatively by the presence of grasses and positively by the presence of legumes in the community (Scherber et al. 2006). Despite these general trends, species may respond idiosyncratically, making it necessary to test a range of plant species.

Plant establishment in an existing community occurs in several stages, arrival, germination, establishment, maintenance and spreading and ideally, all of these steps should be investigated because different factors may be important for the different stages of establishment (Prieur-Richard and Lavorel 2000, White and Shurin 2007). However, most experiments on invasion-resistance in relation to components of diversity in grassland ecosystems were undertaken as 'seed addition experiments' or 'weeding analyses' and investigated but a short period of the establishment process, often as result of experimental, organisational or financial constraints. In addition, biotic interactions other than competition that may also play a role for plant establishment such as predation (herbivory) are rarely studied at the same time. In fact, while there are many studies investigating ecosystem effects of biodiversity at the community level, studies of particular biotic interactions are still rare (Scherber et al. 2006).

In this study we examine the establishment success of Centaurea jacea individuals in a grassland experiment where plant species richness, plant functional group richness and the presence of particular plant functional groups are manipulated systematically. Plants were introduced as seedlings (transplants) approximately three years after the setup of the experiment, i.e. into maturing plant communities, and the fate of the plants was followed over a period of 2.5 years. In addition, we studied the effect of insect herbivory on plant establishment success by treating half of the transplants with insecticide. Establishment of $C$. jacea was measured in terms of performance related parameters such as height, number of flower heads and plant biomass during two flowering seasons.

\section{Materials and Methods}

\section{Experimental design}

This study was undertaken on the field site of the Jena Experiment, located near Jena, Germany, on the flood plain of the river Saale (for details see Roscher et al. 2004). Briefly, 82 large plots of 20x20 $\mathrm{m}$ were established at plant species richness levels of 1, 2, 4, 8, 16 and 60 species, out of a species pool of 60 species belonging to the typical Arrhenaterion-Community characteristic of the surrounding area. Plant species were divided into four functional groups (grasses, small herbs, tall herbs and legumes) and all possible combinations of number of plant species*number of functional 
groups were realized from the 60 species pool. Apart from the 16- and 60- species mixtures each diversity level is replicated 16 times (= 16 plots) without identical species allocation. 16- and 60species mixtures are replicated 14 and four times respectively. Plots are distributed over four blocks (randomized complete block design) holding the same numbers of replicates for each diversity level. To maintain the sown species diversity level all plots are weeded twice to three times per year and differential herbicide is used where possible. Plots are mown twice a year (early summer mowing in early June, autumn mowing in early September) and biomass is removed from the site. Two subplots per main plot ('insecticide' and 'control') were chosen for planting of Centaurea jacea which belongs to the species pool of the experiment. Insecticide (dimethoate - a semi-systemic organothiophosphate) was applied in four weekly rhythms from April to September 2006 and 2007.

\section{Study species Centaurea jacea}

The brown knapweed Centaurea jacea L. s. 1. (Asteraceae) is native to Eurasia and widely distributed all over Germany. It is a perennial hemikryptophyt and produces all aboveground organs newly each year between spring and autumn (Press and Gibbons 1993). Flowering occurs from June to October from the second year onwards and a single plant may produce up to 200 main branches (Stadler 1992).

\section{Planting of Centaurea jacea}

Seeds of $C$. jacea were obtained from Rieger- Hofmann GmbH, Blaufelden-Raboldshausen, Germany. Seeds were pre-germinated in late April 2005 and grown on standard compost: perlite mixture (4:1) in an unheated glasshouse. In early June 820 seedlings were sorted into three different size classes and transferred into pots containing soil of the four different blocks of the experimental field site. Each type of soil (block) received the same proportion of plants from all size classes. Plants were then kept outside to harden until transplantation into the subplots. In early July 2005 five plants each were transplanted into two subplots, insecticide and control, of all 82 diversity plots. Each subplot received a single row of one larger, two medium and two smaller plants, planted $25 \mathrm{~cm}$

apart. In late June and early September transplants were mown together with the general mowing of the field site.

\section{Plant community measurements}

Community biomass of all plant communities was recorded in an untreated subplot $\left(150 \mathrm{~m}^{2}\right)$ of each plot by harvesting biomass within four randomly distributed $20 \times 50 \mathrm{~cm}$ frames. All plants were cut $3 \mathrm{~cm}$ above ground, plant material was then dried $\left(70^{\circ} \mathrm{C}, 48 \mathrm{hrs}\right)$ and weighed. Harvesting took place 
in August 2006 and 2007 before the autumn mowing. Mean total biomass of these four samples was used in the statistical analysis.

\section{Transplant performance}

The number of surviving Centaurea jacea plants was recorded in April 2006, one year after transplanting the individuals; in August 2006, August 2007 and at the end of March 2008.

Transplant biomass (without flower heads) was determined shortly before the second mowing of the field site in August 2006 and 2007. Transplants from all plots were harvested by cutting each individual $3 \mathrm{~cm}$ above ground. All stems and leaves were collected and stored cool until several plant traits were recorded within the following days. Finally plants were decapitated, oven-dried at $70^{\circ} \mathrm{C}$ for 48 hours and weighed.

Between $23^{\text {rd }}$ of August and $1^{\text {st }}$ of September 2006 we measured maximum height using a metering rule and counted the number of flower heads on all individuals. Herbivory was visually estimated in percentage leaf area missing including all visible damage on the largest stem leaf of each plant. Leaf templates from millimetre paper served as reference when judging the proportion damaged.

Between $28^{\text {th }}$ and $31^{\text {st }}$ of August 2007 the number of shoots, basal leaves and flower heads, the length of the largest shoot were recorded and the width of the biggest flower head (identified by visual estimate) was determined using a gauge. Herbivory was estimated visually on the largest stem and basal leaf as above but using a class system (Tab. A). Damage class midpoints were used for statistical analysis. All flower heads were cut before drying and stored in acrylic glass tubes closed with rubber foam plugs for further investigation of associated insects.

\section{Table A:}

Damage classes of percentage leaf area damaged used for herbivory estimation; class midpoints entered the statistical analysis

\begin{tabular}{lc}
\hline Range & percentage class midpoint \\
\hline No damage & 0 \\
Almost no damage & 0.1 \\
Damage less than 1\% & 0.5 \\
1 - $2.9 \%$ damage & 2.0 \\
3 - 4.9\% damage & 4.0 \\
5 - 9.9\% damage & 7.5 \\
$10-19.9 \%$ damage & 15.0 \\
20 - 29.9\% damage & 25.0 \\
$30-40 \%$ damage & 35.0 \\
$>40 \%$ damage & 75.0 \\
\hline
\end{tabular}




\section{Statistical analysis}

Data was analysed using the statistical software R (R Development Core Team, Vienna Austria http://www.R-project.org.). Data were log or square root transformed if Q-Q plots showed deviations from normality. Percentage data (survival of transplants and herbivory estimates) were arcsine transformed before the analysis and if necessary square root transformed thereafter to meet the assumptions of the analysis. Missing data were excluded from the analyses. We analyzed the effect of vegetation terms on survival and performance of Centaurea jacea using analysis of covariance with type-I sums of squares (Crawley 2002, Schmid et al. 2002). Paired t-tests showed no significant differences between the control plots and insecticide plots (transformed data), therefore all replicates were used for calculations of per plot values $(n=82)$. All parameters entered the analysis as mean values per plot except for transplant height and stem length of which the biggest per plot value was used. In a few cases the survival rate of transplants in a particular plot in the preceding year was corrected when a 'missing' individual was found in the following year. The fitted model included factors and interaction terms in the following order: block, community biomass, log (plant species richness, number of functional groups, presence of legumes, grasses, tall herbs, log (plant species richness): number of functional groups, log (plant species richness): legumes, log (plant species richness): tall herbs, legumes: grasses and legumes: tall herbs. The explanatory variable 'community biomass' was included as to test for effects of plant species richness independent of its influence on plant community biomass. Community biomass in our experimental plots has been shown to be positively related to plant species richness (Marquard et al. submitted). Moreover the number of sown plant species has been shown to highly correlate $\left(\mathrm{R}^{2}>\right.$ 0.99) with the number of realised plant species (Marquard et al. submitted).

Exchange of the order of analysis of the two variables 'log (plant species richness)' and 'plant functional group richness' mostly resulted in an additional significant effect of the latter without eliminating the former.

Averages are given as mean \pm standard error and differences between years were tested for significant difference from zero with a paired t-test or a Wilcoxon-test for paired samples if the differences deviated from normal distribution.

\section{Results}

\section{Insect herbivory}

Stem leaf herbivory averaged $4.5 \pm 0.3 \%$ and $5.3 \pm 0.7 \%$ leaf area damaged in 2006 and 2007 respectively. Herbivory on stem leaves did not differ between years $(V=1136, p=0.824)$. Herbivory on basal leaves in 2007 was slightly higher with $7.3 \pm 1 \%$. There were no significant 
differences in herbivory between insecticide and control subplots in 2006 (paired t-test on arcsine transformed data $p=0.36$ ) or 2007 (basal leaves $p=0.088$, stem leaves $p=0.12$ ). In 2007 herbivory on both leaf types was positively influenced by community biomass whereas in 2006 a block effect was detected only (Table 1). Exclusion of community biomass as explanatory variable resulted in an additional interaction of plant species and plant functional group richness in herbivory on stem leaves 2006. While herbivory seems to decrease with increasing plant species richness in communities consisting of only one plant functional group, the opposite seems the case when viewed across plots containing more than one functional group. Furthermore a positive effect of legume presence on herbivory on basal leaves in 2007 was found (Table 1). If control and insecticide subplots were analysed separately, results were different between years. In 2006 block $(F=3.09, p=$ $0.034)$ and plant species diversity $(F=7.13, p=0.001)$ significantly affected herbivory on stem leaves in the control plots whereas no effects were detected in the insecticide treated plots. Increasing plant species richness decreased herbivory in control subplots. Exclusion of community biomass from the analysis lead to the same results for control subplots and yielded a significant interaction between plant functional group richness and plant species richness for insecticide subplots. Both variables show erratic mean values across their gradients. In 2007 the only effect on herbivory in stem leaves detected was a positive influence of community biomass $(F=4.43, p=$ 0.419) in control subplots. Herbivory in basal leaves in 2007 was independent of plant species richness and functional group richness but was significantly and positively affected by the presence of legumes and grasses (control subplots: grass $F=6, p=0.018$; insecticide subplots: legumes, $F=$ 4.24, $p=0.045$ ). Both effects vanished when community biomass was included into the analysis (control subplots: $F=8.4, p=0.006$; insecticide subplots: $F=11.17, p=0.002$ ), which was positively correlated with herbivory. For all measures of plant fitness, there were no significant differences between control and insecticide subplots and all further analyses of plant fitness were therefore performed on the transformed mean values of the variables at the plot level.

\section{Survival of transplants}

Approximately ten months after transplantation of Centaurea seedlings into the experimental plots average survival amounted to $72.8 \%$ in spring 2006. The number of surviving plants decreased further to $64.9 \%$ (autumn 2006), 56.3\% (autumn 2007) and 49.0\% (spring 2008) of originally implanted individuals. Survival until spring 2006 was negatively influenced by community biomass and the presence of legumes (Table 1; Figs.1A-C). A positive impact of grasses was indicated by a significant interaction between grasses and legumes (Table 1, Fig.1D). By exclusion of the explanatory variable community biomass from the model additional effects of plant species richness 
$\left(F_{1,82}=11.163, p=0.001\right)$ and plant functional richness $\left(F_{1,82}=5.648, p=0.02\right)$ were detected which indicates that their negative influence on transplant survival was mediated by community biomass. In order to test if the same variables influenced survival also later in the establishing process we analysed survival from spring 2006 to spring 2008 by calculating survival for 2008 taking the number of surviving plants in spring 2006 as starting point. Plots holding fewer than three transplants in spring 2006 were excluded. Community biomass significantly reduced the number of surviving $C$. jacea plants and the interaction between the number of plant species and functional group richness was also significant (Table 1). For both variables survival rate decreases with increase, however more pronounced across the plant functional group gradient where there was an average survival rate of $73 \%$ in communities containing merely one plant functional group compared to $41 \%$ in communities of four plant functional groups. Exclusion of community biomass from the analysis resulted in significant negative effects of plant species richness, functional group richness and legume presence respectively. The interaction remained significant (Table 1).
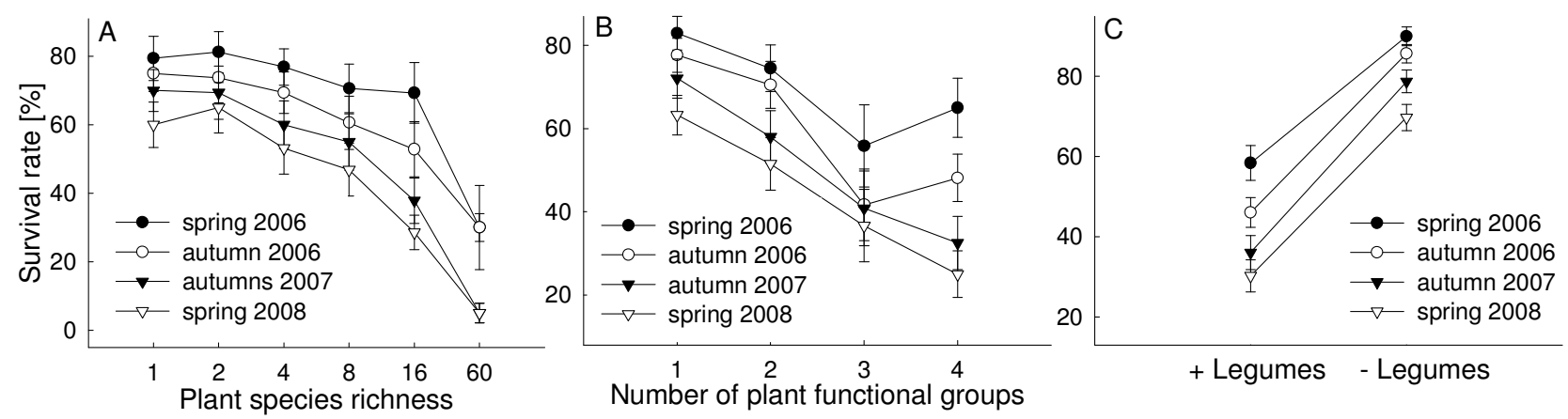

Figure 1:

Relationship between transplant survival and plant species richness (A), functional group richness (B) and legume presence (C) in spring and autumn 2006, autumn 2007 and spring 2008.

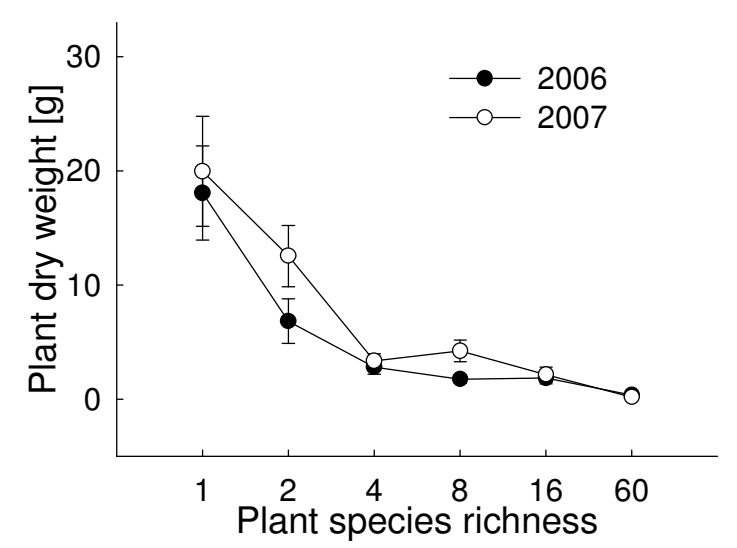

Figure 2:

Relationship between transplant dry weight and plant species richness in 2006 and 2007; an outlier has been excluded from the analysis. 

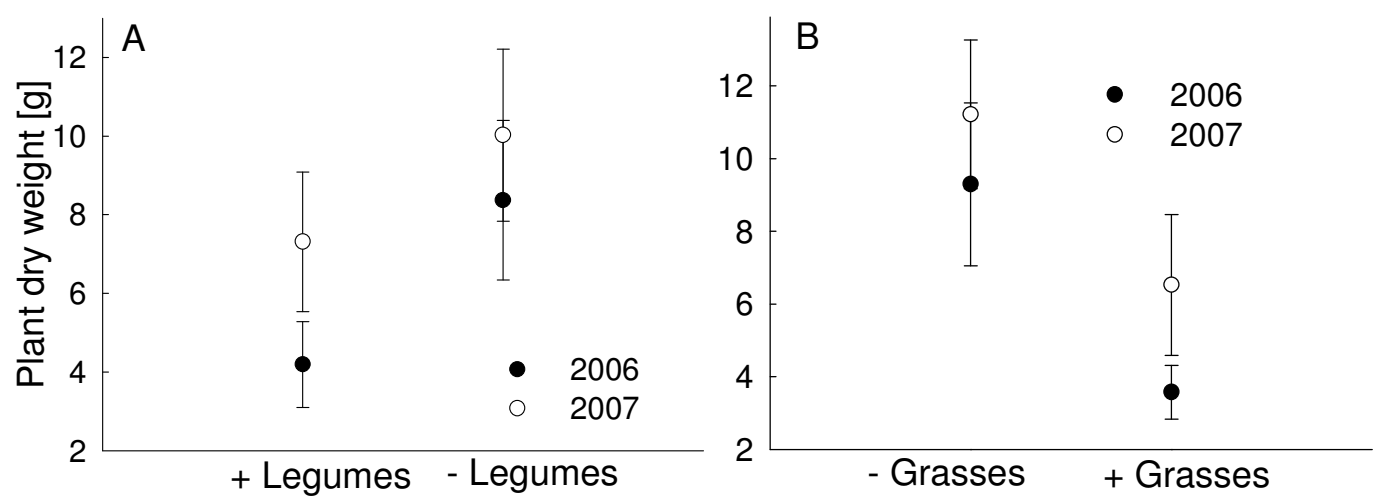

Figure 3:

Relationship between transplant dry weight and plant legume (A) and grass presence (B) respectively in 2006 and 2007 ; an outlier has been excluded from the analysis.

\section{Plant performance traits}

\section{Biomass of $C$. jacea individuals}

Transplant dry weight was twice as high in $2007(12.98 \pm 4.46 \mathrm{~g})$ as in $2006(6.25 \pm 1.16 \mathrm{~g})$. However, the 2007 mean value was strongly influenced by one plot value consisting of a single plant of extraordinary weight (326 g compared to the second heaviest plant of $190 \mathrm{~g}$ and the second largest plot mean of $71 \mathrm{~g}$ ). After exclusion of this case average transplant dry weight in 2007 still exceeded the mean in 2006 by about $2.5 \mathrm{~g}(8.74 \pm 1.42 \mathrm{~g})$. This difference between years was significantly different from zero $(V=575.5, p<0.001)$. The outlier was excluded from the analysis. In 2006 , both plant species richness and community biomass significantly decreased dry weight of $C$. jacea (Table 1; Fig. 2). Additionally a significant interaction of plant species richness and legume presence was found. The negative effect of plant species richness was weakened by the presence of legumes which as well influenced mean dry weight negatively. Exclusion of community biomass from the analysis did not change this result. In 2007, the negative effects of plant community biomass and plant species richness were still significant (Table 1; Fig. 2). In addition, transplant biomass decreased with increasing plant functional group richness and in the presence of legumes (Table 1; Fig. 3A). Transplant dry weight differed between blocks and the presence of grasses negatively affected dry weight of $C$. jacea (Table 1; Fig. 3B). When community biomass was excluded from the analysis the significant effects of plant species richness and the presence of grasses disappeared. Thus, both in 2006 and 2007 the plant species richness effects on transplant biomass were not mediated by community biomass, and were in fact only detected in 2007 when the variation caused by plant community biomass was excluded from the model. 

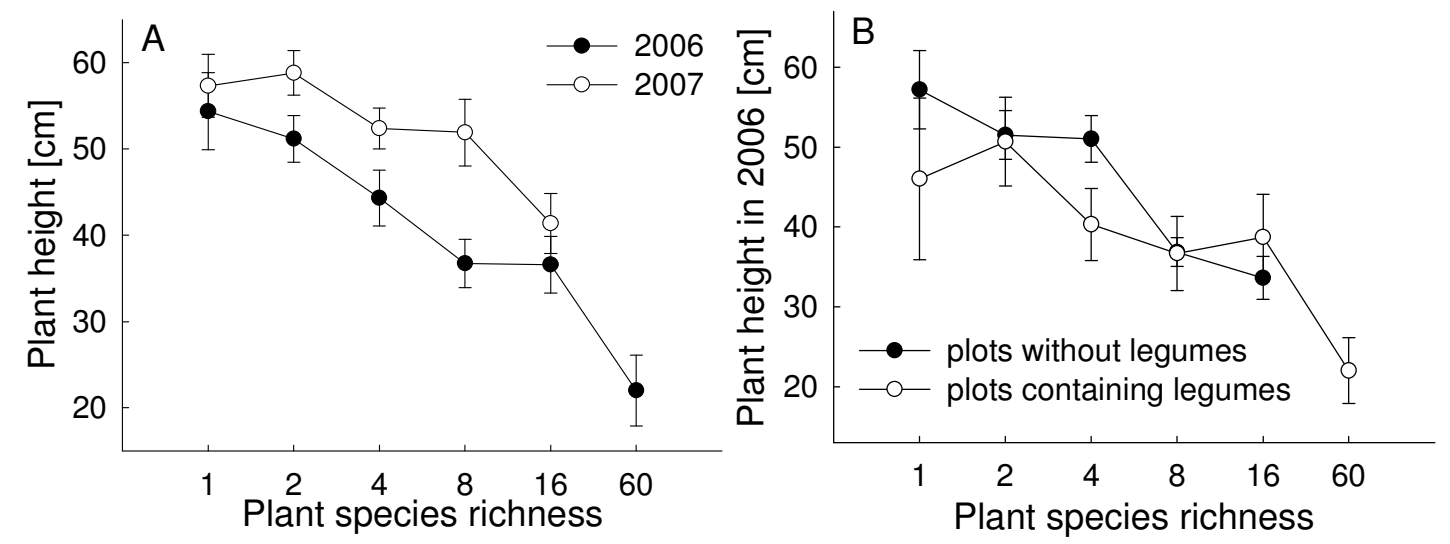

Figure 4:

Relationship between transplant height and plant species richness of A) both years and B) for 2006, showing differences between plots with and without legumes.

\section{Transplant height}

C. jacea plants grew higher in 2007 with $53.7 \pm 1.63 \mathrm{~cm}$ average maximum shoot length than in 2006 when maximum plant height averaged $44 \pm 1.72 \mathrm{~cm}(t=-5.92, p<0.001)$. In 2006 community biomass and plant species richness both influenced plant height negatively and a significant interaction between plant species richness and legume presence (Fig. 4A-B) revealed the overall negative impact of legume presence on plant height. C. jacea plants in monocultures were on average $54.4 \mathrm{~cm}$ high and plants in communities of 16 sown species grew to an average height of $36.6 \mathrm{~cm}$. Exclusion of community biomass from the analyses did not change the results. In 2007 only plant species richness significantly decreased transplant height; the legume effect was no longer significant. Both in 2006 and 2007 transplant heights differed between blocks.

\section{Number of shoots and basal leaves}

Leaves and shoots were counted in 2007 only. Plants produced $6.1 \pm 1$ shoots and $33.5 \pm 2.9$ basal leaves on average. Both plant traits were negatively influenced by increasing community biomass and plant species richness (Table 1; Fig. 5A). Additionally the number of shoots decreased with increasing number of functional groups (Table 1, Fig. 5B). Results for neither variable changed when community biomass was excluded from the analysis. 

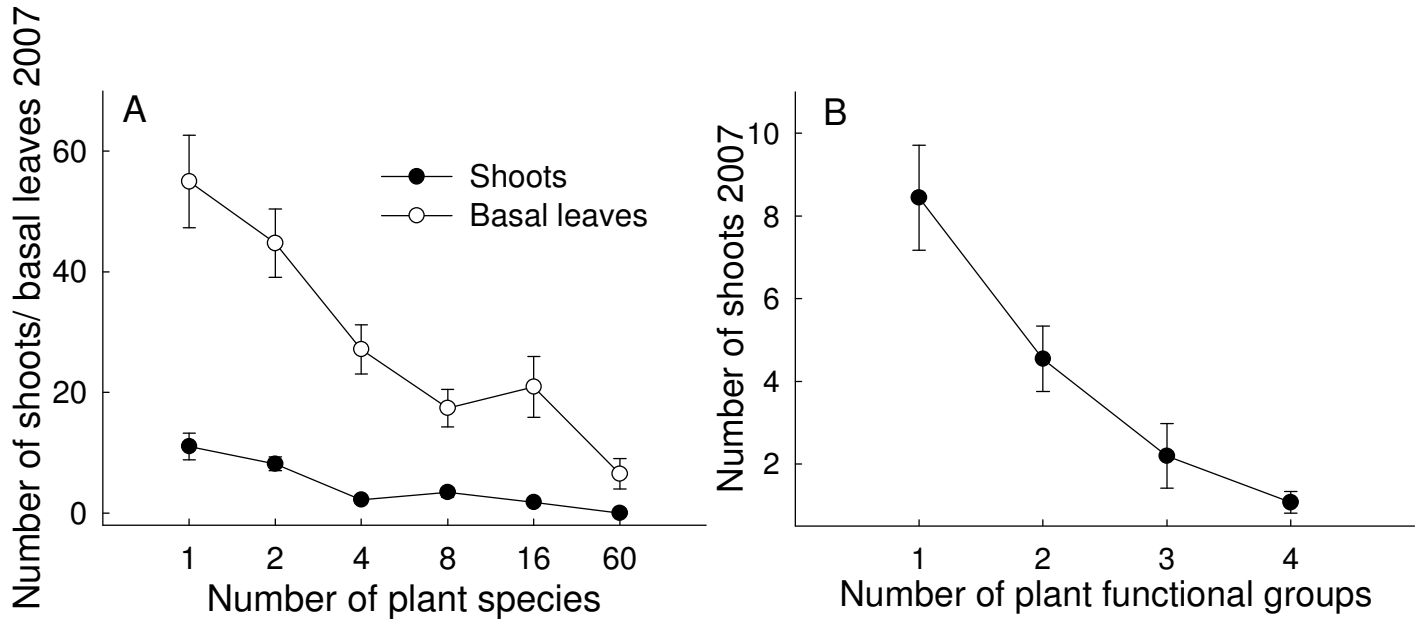

Figure 5:

Relationship between number of shoots and basal leaves in 2007and plant species richness (A); number of shoots in 2007 in relation to plant functional group richness (B).
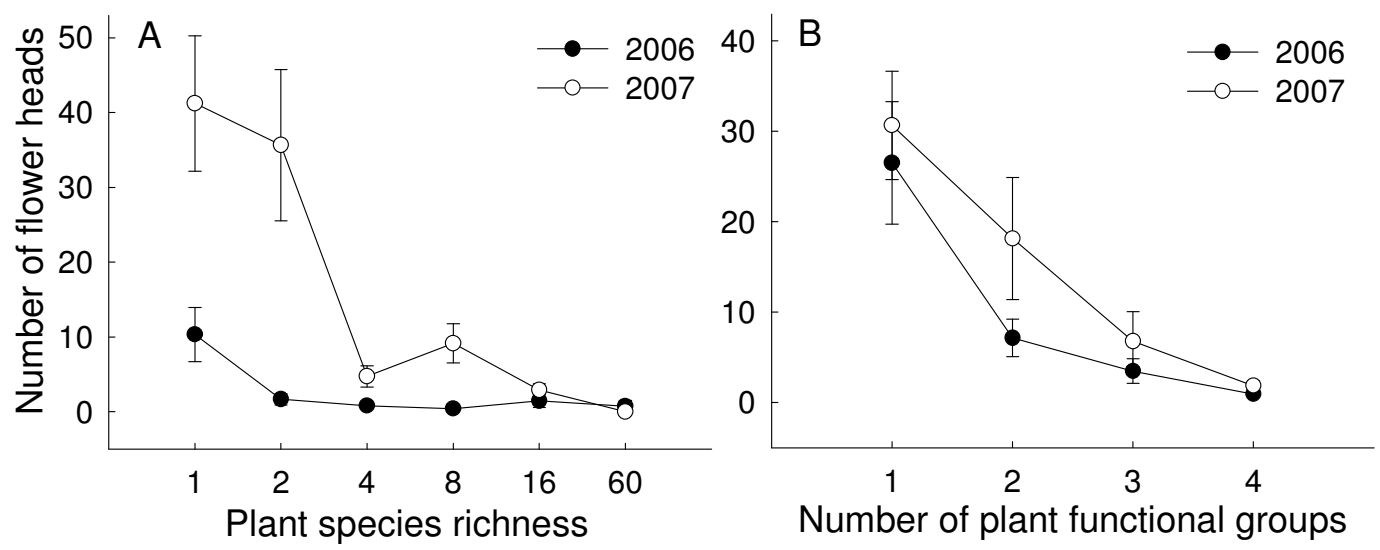

Figure 6:

Relationship between number of flower heads and plant species richness (A) and plant functional richness (B) in 2006 and 2007.

\section{Flower heads and phenological state}

The average number of flower heads was higher in 2007 than in 2006 with $19.6 \pm 3.5$ and $13.8 \pm 3.2$ flower heads per surviving transplant, respectively $(V=643.5, p=0.001)$. Thus, as also seen in transplant biomass and height, plants grew considerably bigger from 2006 to 2007. In both years the number of flower heads was negatively influenced by community biomass, plant species richness and plant functional group richness (Table 1; Fig. 6A-B). A significant interaction between plant species richness and plant functional group richness occurred for the number of flower heads in 2006 (Table 1). Additionally legume presence significantly decreased the number of flower heads in 2007. This legume effect disappeared when community biomass was excluded from the analysis. 
The proportion of flower heads that were blooming was positively influenced by plant species richness in 2006 and an interaction between plant species and functional group richness was detected (Table 1). In contrast to the species richness gradient the functional group gradient showed erratic mean values of proportion of blooming flower heads. Exclusion of community biomass from the analysis resulted in a significant negative legume effect. In 2007 the patterns were different. Besides a block effect, community biomass and plant functional group richness both reduced the proportion of blooming heads (Table 1). The interaction between legume presence and plant species richness was also significant. While in the absence of legumes the proportion hardly changed across plant species richness levels, response in plots without legumes was rather erratic with the lowest average proportion of blooming heads in 4 species mixtures (Table 1). Exclusion of community biomass did not change these results.

The width of the largest flower head per plant in 2007 averaged $0.88 \pm 0.03 \mathrm{~cm}$ and was negatively influenced by plant species richness (Table 1; Fig. 7), especially in the absence of legumes (Table 1). When legumes were present the correlation was less clear. Besides this interaction a second interaction referring to legume and grass presence was detected. When legumes were present the average width of flower heads in grass plots amounted to $0.74 \mathrm{~cm}$ while plots without grass had an average width of $0.97 \mathrm{~cm}$. In plots without legumes there was hardly a difference between plots including grass and those without. Exclusion of community biomass from the analysis yielded the same results.

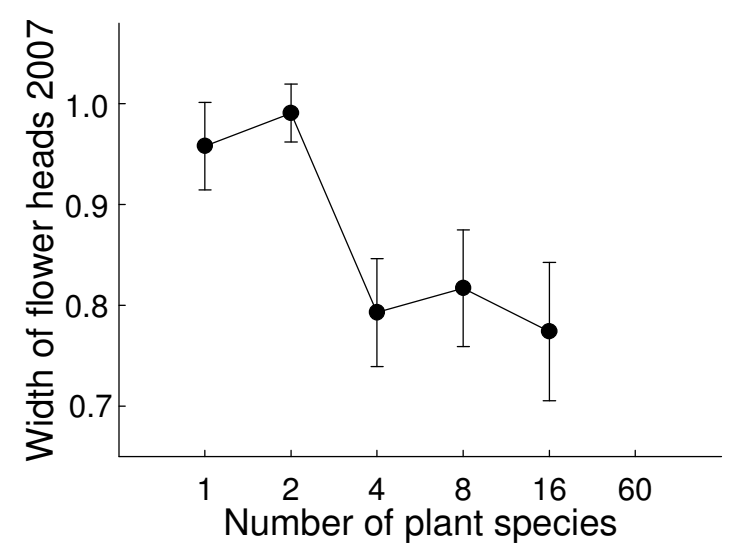

Figure 7:

Relationship between width of transplant flower heads and plant species richness. 


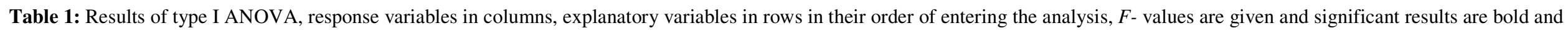

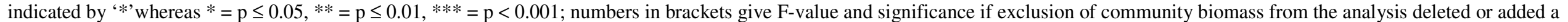

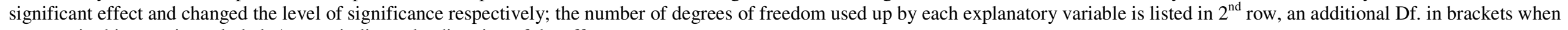
community biomass is excluded. Arrows indicate the direction of the effects.

\begin{tabular}{|c|c|c|c|c|c|c|c|c|c|c|c|c|}
\hline Source & $\begin{array}{l}\text { number of } \\
\text { observations }\end{array}$ & block & $\begin{array}{l}\text { community } \\
\text { biomass } \\
(\mathrm{g} / \mathrm{m} 2) \\
\end{array}$ & $\begin{array}{l}\text { plant species } \\
\text { richness } \\
\text { (SR) }\end{array}$ & $\begin{array}{l}\text { plant } \\
\text { functional } \\
\text { groups } \\
\text { (\#FG) } \\
\end{array}$ & $\begin{array}{l}\text { presence of } \\
\text { legumes } \\
\text { (legumes) } \\
\end{array}$ & $\begin{array}{l}\text { presence } \\
\text { of grasses } \\
\text { (grasses) }\end{array}$ & $\begin{array}{l}\text { presence } \\
\text { of tall } \\
\text { herbs } \\
\text { (therbs) }\end{array}$ & $\mathbf{S R} * \# \mathbf{F G}$ & $\begin{array}{l}\text { SR * } \\
\text { legumes }\end{array}$ & $\begin{array}{l}\text { legumes * } \\
\text { grasses }\end{array}$ & $\begin{array}{l}\text { legumes } \\
* \text { tall } \\
\text { herbs } \\
\end{array}$ \\
\hline Num. Df. & & & 1 & 1 & 1 & 1 & 1 & & 1 & 1 & 1 & 1 \\
\hline Percent survival until spring $2006^{\mathrm{a}}$ & 82 & 0,25 & $42,51 * * * \downarrow$ & 0,19 & 1,58 & $13,86 * * * \downarrow$ & $2,06(\uparrow)$ & 3,18 & 1,63 & 0,33 & $9,03 * *$ & 0,45 \\
\hline $\begin{array}{l}\text { Percent survival since spring } 2006^{\mathrm{b}} \\
\text { (exclusion of plots with indiv }<4 \text { in } \\
\text { spring 2006) }\end{array}$ & $69(+1)$ & $3,41 *$ & $59,12 * * * \downarrow$ & $\begin{array}{l}1,98 \\
(\mathbf{2 6 , 0 5} * * * \downarrow)\end{array}$ & $\begin{array}{l}1,64 \\
(\mathbf{5}, \mathbf{8 8} \downarrow *)\end{array}$ & $\begin{array}{l}1,02 \\
(\mathbf{9 , 5 4} * * \downarrow)\end{array}$ & 0,00 & 0,13 & $\begin{array}{l}7,66 * * \\
(12,65 * * *)\end{array}$ & 0,55 & 0,09 & 3,98 \\
\hline Transplant-Biomass $2006^{\mathrm{c}}$ & 79 & 1,15 & $26,64 * * * \downarrow$ & $45,6 * * * \downarrow$ & 2,62 & 3,31 & 1,73 & 0,45 & 0,52 & $5,32 *$ & 0,05 & 0,22 \\
\hline Transplant-Biomass $2007^{\mathrm{c}^{\wedge}}$ & $74(+1)$ & $2,76 *$ & $22,88 * * * \downarrow$ & $46,18 * * * \downarrow$ & $\begin{array}{l}\mathbf{5 , 6 8} * \downarrow \\
(3,27)\end{array}$ & $\begin{array}{l}7,82 * * \downarrow \\
(6,66 *)\end{array}$ & $\begin{array}{l}\mathbf{4 , 6} * \downarrow \\
(1,19)\end{array}$ & 0,35 & 2,74 & 3,31 & 0,04 & 0,04 \\
\hline Max. plant height 2006 & 79 & $3,98 *$ & $17,08 * * * \downarrow$ & $24,14 * * * \downarrow$ & 2,38 & $0,21(\downarrow)$ & 0,08 & 0,01 & 0,03 & $7,1 *$ & 0,45 & 0,05 \\
\hline Max. shoot length 2007 & 68 & $3,03 *$ & 1,01 & $12,97 * * * \downarrow$ & 3,01 & 0,24 & 0,27 & 0,45 & 1,13 & 3,78 & 0,09 & 0,34 \\
\hline Number of shoots $2007^{c}$ & 75 & 0,98 & $19,52 * * * \downarrow$ & $22,01 * * * \downarrow$ & $4,42 * \downarrow$ & 1,7 & 0,06 & 0,32 & 1,12 & 1,4 & 0 & 0,09 \\
\hline Number of flower heads $2006^{c}$ & $79(+1)$ & 1,7 & $28,75 * * * \downarrow$ & $32,75 * * * \downarrow$ & $5,62 * \downarrow$ & 0,37 & 2,24 & 0,22 & $\begin{array}{l}7,43 * * \\
(4,81 *)\end{array}$ & 2,58 & 0,01 & 0,00 \\
\hline Number of flower heads $2007^{c}$ & $75(+1)$ & 0,99 & $18,37 * * * \downarrow$ & $33,14 * * * \downarrow$ & $6,02 * \downarrow$ & $\begin{array}{l}\mathbf{4 , 3 2} * \downarrow \\
(2,35)\end{array}$ & 1,55 & 0,2 & 1,61 & 0,81 & 0,01 & 0,00 \\
\hline Proportion of blooming heads $2006^{\mathrm{d}}$ & $63(+1)$ & 1,24 & 2,98 & $\begin{array}{l}\mathbf{8 , 7 5} * * \uparrow \\
(3,51)\end{array}$ & 0,01 & $\begin{array}{l}3,7 \\
(\mathbf{1 0}, \mathbf{1 5} * * \downarrow)\end{array}$ & 0,51 & 0,21 & $9,43 * *$ & 0,45 & 0,07 & 0,2 \\
\hline Proportion of blooming heads 2007 & 68 & $4,15 *$ & $5,49 * \downarrow$ & 0,53 & $8,97 * * \downarrow$ & 0,08 & 0,55 & 0,23 & 1,37 & $5,45 *$ & 0,35 & 1,17 \\
\hline Herbivory on stem leaves $2006^{b}$ & $79(+1)$ & $3,48 *$ & 0,11 & 2,36 & 2,5 & 0,99 & 0,00 & 0,33 & $\begin{array}{l}3,65 \\
(\mathbf{4 , 6} *)\end{array}$ & 0,00 & 0,18 & 0,06 \\
\hline Herbivory on stem leaves $2007^{b}$ & 68 & 0,86 & $4,97 * \uparrow$ & 0,03 & 0,33 & 1,15 & 0,01 & 0,04 & 3,19 & 0,42 & 1,3 & 0,01 \\
\hline Herbivory on basal leaves $2007^{\mathrm{b}}$ & $74(+1)$ & 0,84 & $\mathbf{1 1 , 8 3} * * \uparrow$ & 1,21 & 0,39 & $\begin{array}{l}0,84 \\
(\mathbf{5 , 6 1} * \uparrow)\end{array}$ & 0,08 & 1,24 & 1,31 & 0,32 & 0,27 & 0,95 \\
\hline Number of basal leaves $2007^{c}$ & 75 & 1,38 & $12,14 * * * \downarrow$ & $16,6 * * * \downarrow$ & 0,54 & 0,45 & 1,23 & 1,11 & 0,16 & 0,01 & 0,01 & 0,2 \\
\hline Max. width of flower heads 2007 & 68 & 0,8 & 1,47 & $12,85 * * * \downarrow$ & 3,32 & 1,81 & 0,11 & 0,04 & 1,03 & $8,25 * *$ & $4,33 *$ & 0,03 \\
\hline
\end{tabular}

Abbreviations: $\mathrm{a}=$ arcsine, $\mathrm{b}=$ arcsine square root, $\mathrm{c}=$ logarithmic, $\mathrm{d}=$ square $\operatorname{root}, \wedge=1$ case excluded from analysis 


\section{Discussion}

Seedlings of the tall herb Centaurea jacea, which is part of the species pool of the Jena Experiment, were transplanted into 82 experimental plant communities and their fate was followed for a period of 2.5 years. During this time, a good proportion ( $>50 \%$ ) of individuals did not manage to survive and there were strong negative effects of plant species richness and the presence of legumes on survival. Those individuals that survived grew significantly larger over the period of two years but there were still significant effects of the resident plant community on transplant performance after two years. The differences between diversity levels were striking: basically $5 \%$ of transplants survived in the 60 -species plots compared to $>60 \%$ of initially transplanted individuals in the one and two-species mixtures. After two years, mean transplant biomass in monocultures was about 10 times the biomass of individuals in the 16-species mixtures. In the following, we will compare our results to previous studies.

Our results are consistent with a number of previous studies that also found decreased survival and fitness of invaders with increasing plant species richness of the resident community (e.g. Naeem et al 2000, Diemer et al. 2002). In the Jena Experiment itself, however, results have been mixed: Mwangi et al. (2007) found that overall performance of four transplant species from four different plant functional groups (a grass, a legume, a tall herb and a small herb) was negatively related to species richness of the resident plant community. In contrast Scherber et al. (2007) found that in Rumex acetosa survival increased with increasing plant species richness. In Scherber et al.'s study, species richness negatively affected the number of main inflorescence axes as well as their length whereas it had no effect on transplant height. Both studies differ also from ours in that they found negative effects of grass presence and mainly positive effects of the presence of legumes on the focal plants, except for the legume Trifolium pratense which was negatively affected by the presence of legumes in the plant community (cf. Fargione et al. 2003, Turnbull et al. 2005). Legumes can promote the growth of plants new to a community because they increase the plant-available nitrogen in the communities (Palmer and Maurer 1997, Prieur-Richard et al. 2002, Temperton et al. 2007). We found consistently negative effects of legumes on traits of Centaurea jacea. Partly, these results were mediated by plant community biomass which is higher in communities with legumes (Roscher et al. 2005, Marquard et al. submitted) as indicated by a lacking effect of legumes when community biomass was added as a covariate to the model. Increasing community biomass indicates that transplants find themselves surrounded by more, bigger or taller plants, resulting in increased transplant shading. The species richness effects 
were, however, rarely affected by the inclusion of the community biomass term in the model, indicating that it is not only shading alone but other mechanisms that negatively affect transplants in the more diverse communities. One possibility is belowground competition, even though belowground community biomass is independent of plant species richness (Bessler et al. 2007). In a separate study, however, Mwangi et al. (submitted) found negative effects of species richness on transplants when aboveground competition was removed experimentally, showing that belowground competition is more intense in more diverse communities. Tracer experiments are necessary to follow the fate of resources belowground in mixtures of different diversity levels. In contrast to other studies, the presence of grasses played a minor role for the establishment of brown knapweed. It is possible that grasses are more important at the germination stage of the invasion process although negative effects of grasses on transplants have also been described (e.g. Scherber et al. 2006).

Leaf herbivory measured as leaf area lost was around four to seven percent on average which is comparable to herbivory in Rumex acetosa transplants (Scherber et al. 2006) but lower than mean herbivory in some natural grasslands (Unsicker et al. 2006, Weisser and Siemann 2004). The only significant effect of plant species richness on herbivory was detected in 2006 in untreated subplots and supports what is expected from theory (Root 1973) where it is assumed that herbivore load is lower in more diverse communities because specialist insect herbivores are less likely to find and stay on their host plants. However, this effect was not consistent between measurements and the interactions between number of plant functional groups and species richness did not show consistent patterns either. Herbivory in our experiment was also independent of transplant biomass $(p=0.335)$. The most consistent effect on herbivory was the positive influence of community biomass. Increasing plant community biomass increases insect abundance (Siemann 1998, Perner et al. 2005, Voigt et al. unpublished.

What is surprising is that insecticide treatment did not affect mean herbivory and plant performance. The compound used, Dimethoate has proved reliable in many studies (Hector et al. 2004) including one in the Jena experiment (Scherber et al. 2006). Leaf-chewing insects do not die immediately when feeding on the plants hence a certain level of herbivory cannot be avoided. In addition, slugs are not killed and are also main herbivores in grasslands. Dimethoate is quasi-systemic and acts mainly against sucking and mining insects. Insects in the flower heads of $C$. jacea were much reduced in abundance in the insecticide subplots Nitschke et al. (in prep.) but the lack of fitness effects of herbivory shows that sucking insects such as aphids Uroleucon jacea (Stadler 1994) played a minor role for the transplants and were indeed very rarely observed. 
We observed the process of community invasion over 2.5 years and found that even after two years there was significant mortality among transplants which indicates that more transplants will die in the near future. Those plants in species-rich communities with legumes are likely to be the next victims. There are also 'delicate hints' that time is important and that during invasion different processes may act at different times. For example, legume presence reduced survival rate independent of plant community biomass only during the first year after transplantation. Moreover effects of particular functional groups independent od plant community biomass were only detected in 2007 (i.e. negative legume effects on transplant biomass and the number of flower heads, negative effect of grass presence on transplant biomass).

In conclusion, we have shown that diverse communities in a controlled set-up are more resistant against the introduction of new species than species-poor ones. There are subtle and not-so-subtle differences to other studies, e.g. differences in the effects of legumes and grasses on transplant survival, and there are certain plant traits that are more affected than others (e.g. plant height vs. number of leaves). This shows that detailed case studies such as the present one are needed to assess the role of factors affecting community assembly and that certain responses of species may be idiosyncratic.

\section{Acknowledgements}

We thank the team that maintains the Jena Experiment, in particular our gardeners and the many student helpers; in particular we thank the student field course who recorded plant traits in 2007. Bernhard Schmid, Ernst-Detlef Schulze, Jens Schumacher and Christiane Roscher were pivotal in setting up the experiment. This research was supported by grants from the Deutsche Forschungsgemeinschaft DFG.

\section{References}

Bessler, H., Temperton, V., Roscher, C., Buchmann, N., Schmid, B., Schulze, E. D., Weisser, W. W. and Engels, C. 2007. Aboveground overyielding in experimental grassland mixtures is related to altered biomass partitioning to belowground organs. -: 1-.

Burke, M. J. W. and Grime, J. P. 1996. An experimental study of plant community invasibility. - Ecology 77: 776-790.

Crawley, M. J. 2002. Statistical computing. An introduction to data analysis using S-Plus. John Wiley \& Sons, Ltd. 
Crawley, M. J., Brown, S. L., Heard, M. S. and Edwards, G. R. 1999. Invasion-resistance in experimental grassland communities: species richness or species identity? - Ecology Letters 2: 140-148.

Diemer, M. and Schmid, B. 2001. Effects of biodiversity loss and disturbance on the survival and performance of two Ranunculus species with differing clonal architectures. Ecography 24: 59-67.

Dukes, J. S. 2002. Species composition and diversity affect grassland susceptibility and response to invasion. - Ecological Applications 12: 602-617.

Elton, C. S. 1958. The ecology of invasions by animals and plants. - Methuen and Co. Ltd.

Emery, S. M. and Gross, K. L. 2006. Dominant species identity regulates invasibility of oldfield plant communities. - Oikos 115: 549-558.

Fargione, J., Brown, C. S. and Tilman, D. 2003. Community assembly and invasion: An experimental test of neutral versus niche processes. - Proceedings of the National Academy of Sciences of the United States of America 100: 8916-8920.

Fargione, J., Brown, C. S. and Tilman, D. 2004. Community assembly and invasion: An experimental test of neutral versus niche processes (vol 100, pg 8916, 2003) - Correction. Proceedings of the National Academy of Sciences of the United States of America 101: 414-414.

Fargione, J. E. and Tilman, D. 2005. Diversity decreases invasion via both sampling and complementarity effects. - Ecology Letters 8: 604-611.

Hector, A., Dobson, K., Minns, A., Bazeley-White, E. and Hartley Lawton, J. 2001. Community diversity and invasion resistance: An experimental test in a grassland ecosystem and a review of comparable studies. - Ecological Research 16: 819-831.

Hector, A., Wilby, A., Latsch, O. and Brown, V. 2004. Phyto-activity of biocides used to manipulate herbivory: tests of three pesticides on fourteen plant species. - Basic and Applied Ecology 5: 313-320.

Hooper, D. U., Chapin, F. S., Ewel, J. J., Hector, A., Inchausti, P., Lavorel, S., Lawton, J. H., Lodge, D. M., Loreau, M., Naeem, S., Schmid, B., Setala, H., Symstad, A. J., Vandermeer, J. and Wardle, D. A. 2005. Effects of biodiversity on ecosystem functioning: A consensus of current knowledge. - Ecological Monographs 75: 3-35.

Kennedy, T. A., Naeem, S., Howe, K. M., Knops, J. M. H., Tilman, D. and Reich, P. 2002. Biodiversity as a barrier to ecological invasion. - Nature 417: 636-638.

Knops, J. M. H., Tilman, D., Haddad, N. M., Naeem, S., Mitchell, C. E., Haarstad, J., Ritchie, M. E., Howe, K. M., Reich, P. B., Siemann, E. and Groth, J. 1999. Effects of plant species 
richness on invasion dynamics, disease outbreaks, insect abundances and diversity. Ecology Letters 2: 286-293.

Levine, J. M. 2000. Species diversity and biological invasions: Relating local process to community pattern. - Science 288: 852-854.

Levine, J. M., Adler, P. B. and Yelenik, S. G. 2004. A meta-analysis of biotic resistance to exotic plant invasions. - Ecology Letters 7: 975-989.

Lyons, K. G. and Schwartz, M. W. 2001. Rare species loss alters ecosystem function invasion resistance. - Ecology Letters 4: 358-365.

Marquard, E., Weigelt, A., Temperton, V. M., Roscher, C., Schumacher, J., Buchmann, N., Fischer, M., Weisser, W. W. and Schmid, B. 2008. Plant species richness and functional composition drive overyielding in a 6-year grassland experiment. - submitted.

Mwangi, P. N., Scherber, C., Schmitz, M., Scherer-Lorenzen, M., Weisser, W. W., Schulze, E.-D. and Schmid, B. 2008. Biodiversity and invasion resistance. - submitted.

Mwangi, P. N., Schmitz, M., Scherber, C., Roscher, C., Schumacher, J., Scherer-Lorenzen, M., Weisser, W. W. and Schmid, B. 2007. Niche pre-emption increases with species richness in experimental plant communities. - Journal of Ecology 95: 65-78.

Naeem, S., Knops, J. M. H., Tilman, D., Howe, K. M., Kennedy, T. and Gale, S. 2000. Plant diversity increases resistance to invasion in the absence of covarying extrinsic factors. Oikos 91: 97-108.

Palmer, M. W. and Maurer, T. A. 1997. Does diversity beget diversity? A case study of crops and weeds. - Journal of Vegetation Science 8: 235-240.

Perner, J., Wytrykush, C., Kahmen, A., Buchmann, N., Egerer, I., Creutzburg, S., Odat, N., Audorff, V. and Weisser, W. W. 2005. Effects of plant diversity, plant productivity and habitat parameters on arthropod abundance in montane European grasslands. - Ecography 28: $1-14$.

Press, B. and Gibbons, B. 1993. Wild flowers of Britain and Europe. - New Holland (Publishers) Ltd.

Prieur-Richard, A. H. and Lavorel, S. 2000. Invasions: the perspective of diverse plant communities. - Austral Ecology 25: 1-7.

Prieur-Richard, A. H., Lavorel, S., Dos Santos, A. and Grigulis, K. 2002. Mechanisms of resistance of Mediterranean annual communities to invasion by Conyza bonariensis: effects of native functional composition. - Oikos 99: 338-346. 
Prieur-Richard, A.-H., Lavorel, S., Linhart, Y. B. and Dos Santos, A. 2002. Plant diversity, herbivory and resistance of a plant community to invasion in Mediterranean annual communities. - Oecologia 130: 96-104.

Root, R. B. 1973. Organization of a plant-arthropod association in simple and diverse habitats: The fauna of collards (Brassica oleracea). - Ecological Monographs 43: 95-124.

Roscher, C., Schumacher, J., Baade, J., Wilcke, W., Gleixner, G., Weisser, W. W., Schmid, B. and Schulze, E. D. 2004. The role of biodiversity for element cycling and trophic interactions: an experimental approach in a grassland community. - Basic and Applied Ecology 5: 107-121.

Roscher, C., Temperton, V. M., Scherer-Lorenzen, M., Schmitz, M., Schumacher, J., Schmid, B., Buchmann, N., Weisser, W. W. and Schulze, E. D. 2005. Overyielding in experimental grassland communities - irrespective of species pool or spatial scale. (vol 8, pg 419, 2005). - Ecology Letters 8: 576-577.

Scherber, C., Milcu, A., Partsch, S., Scheu, S. and Weisser, W. W. 2006. The effects of plant diversity and insect herbivory on performance of individual plant species in experimental grassland. - Journal of Ecology 94: 922-931.

Scherber, C., Mwangi, P. N., Temperton, V. M., Roscher, C., Schumacher, J., Schmid, B. and Weisser, W. W. 2006. Effects of plant diversity on invertebrate herbivory in experimental grassland. - Oecologia 147: 489-500.

Schmid, B., Hector, A., Huston, M. A., Inchausti, P., Nijs, I., Leadley, P. W. and Tilman, D. 2002. The design and analysis of biodiversity experiments. - In: Loreau, M., Naeem, S. and Inchausti, P. (eds.), Biodiversity and Ecosystem Functioning: Synthesis and Perspectives. Oxford University Press, pp. 61-75.

Seastedt, T. R. and Suding, K. N. 2007. Biotic constraints on the invasion of diffuse knapweed (Centaurea diffusa) in North American grasslands. - Oecologia 151: 626-636.

Siemann, E. 1998. Experimental tests of effects of plant productivity and diversity on grassland arthropod diversity. - Ecology 79: 2057-2070.

Spehn, E. M., Joshi, J., Schmid, B., Diemer, M. and Korner, C. 2000. Above-ground resource use increases with plant species richness in experimental grassland ecosystems. Functional Ecology 14: 326-337.

Stadler, B. 1992. Ökophysiologische und ökoethologische Beziehungen in einem PflanzenHerbivoren-Modellsystem: Centaurea Jacea-uroleucon jaceae. Dissertation. - Universität Bayreuth, pp. 1-111. 
Stadler, B. 1992. Physiological responses of Uroleucon jaceae (L.) to seasonal changes in the quality of its host plant Centaurea jacea L.: Multilevel control of adaptations to the life cycle of the host. - Oecologia 91: 273- 280.

Stadler, B., Weisser, W. W. and Houston, A. I. 1994. Defense reactions in aphids - the influence of state and future reproductive success. - Journal of Animal Ecology 63: 419430.

Symstad, A. J. 2000. A test of the effects of functional group richness and composition on grassland invasibility. - Ecology 2000: 99-109.

Temperton, V. M., Mwangi, P. N., Scherer-Lorenzen, M., Schmid, B. and Buchmann, N. 2007. Positive interactions between nitrogen-fixing legumes and four different neighbouring species in a biodiversity experiment. - Oecologia 151: 190-205.

Tilman, D. 1997. Community invasibility, recruitment limitation, and grassland biodiversity. Ecology 78: 81-92.

Tilman, D., Knops, J., Wedin, D., Reich, P., Ritchie, M. and Siemann, E. 1997. The influence of functional diversity and composition on ecosystem processes. - Science 277: 1300-1302.

Tilman, D., Lehman, C. L. and Thomson, K. T. 1997. Plant diversity and ecosystem productivity: Theoretical considerations. - Proceedings of the National Academy of Science of the United States of America 94: 1857-1861.

Turnbull, L. A., Rahm, S., Baudois, O., Eichenberger-Glinz, S., Wacker, L. and Schmid, B. 2005. Experimental invasion by legumes reveals non-random assembly rules in grassland communities. - Journal of Ecology 93: 1062-1070.

Unsicker, S. B., Baer, N., Kahmen, A., Wagner, M., Buchmann, N. and Weisser, W. W. 2006. Invertebrate herbivory along a gradient of plant species diversity in extensively managed grasslands. - Oecologia 150: 233-246.

van Ruijven, J., De Deyn, G. B. and Berendse, F. 2003. Diversity reduces invasibility in experimental plant communities: the role of plant species. - Ecology Letters 6: 910-918.

Weisser, W. W. and Siemann, E. (eds.). 2004. Insects and ecosystem function. - SpringerVerlag Berlin.

Weisser, W. W. and Siemann, E. 2004. The various effects of insects on ecosystem functioning. - In: Weisser, W. W. and Siemann, E. (eds.), Insects and Ecosystem Function. Springer Ecological Studies, pp. 3-19.

White, L. F. and Shurin, J. B. 2007. Diversity effects on invasion vary with life history stage in marine macroalgae. - Oikos 116: 1193-1203. 


\section{CHAPTER 3}

HOW DOES PLANT SPECIES RICHNESS AFFECT POLLINATOR RICHNESS AND TEMPORAL STABILITY OF FLOWER VISITS?

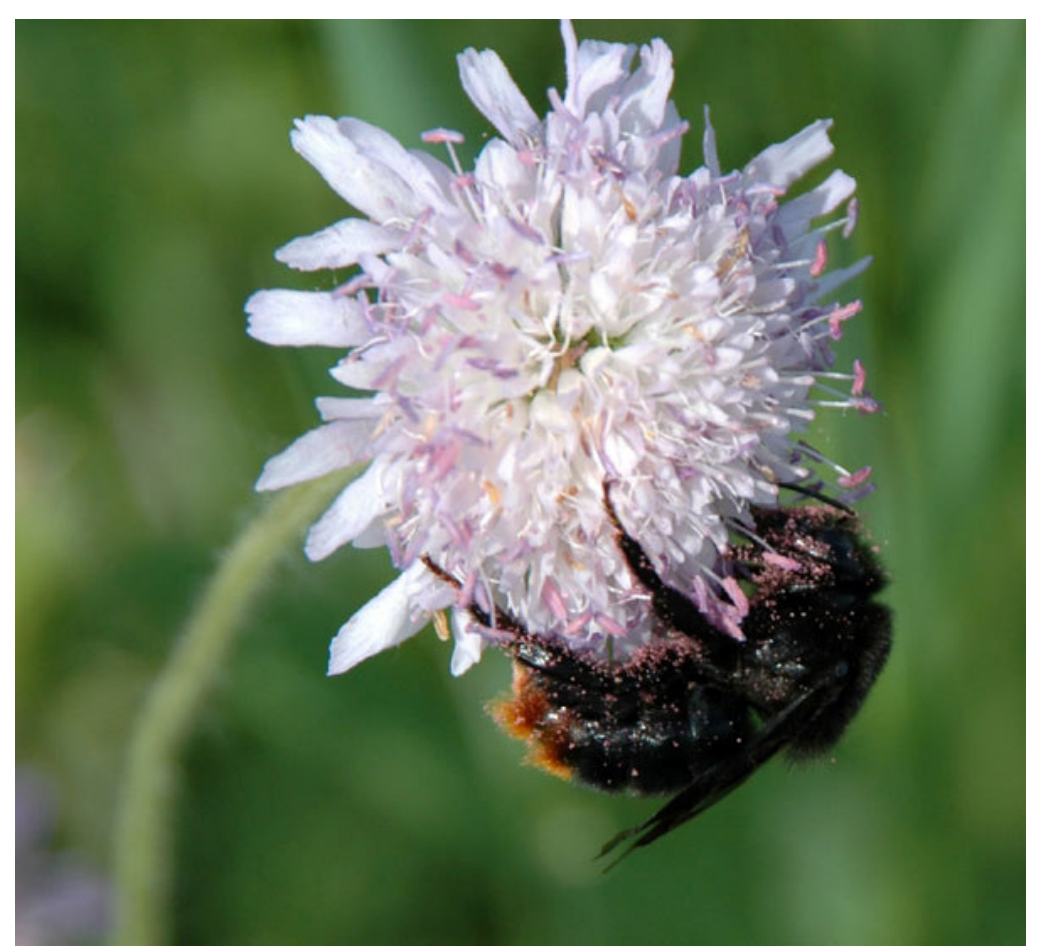




\begin{abstract}
Pollinators play a key role in the reproduction of most plant species, and pollinator and plant diversity are often related. We studied an experimental plant diversity gradient for a better understanding of plant-pollinator community interactions and their temporal variability, because in non-experimental field surveys plant richness is often confounded with gradients in management, soil fertility and community composition. We observed pollinator species richness and frequency of visits six times in 73 plots over two years, and used advanced statistical analysis to account for the high number of zeroes that often occur at count data of rare species. Pollinator species richness and the frequency of pollinator visits (in particular honey bees and bumble bees) increased with increasing number of flowering plant species and percent blossom cover. Pollinator species richness increased up to a blossom cover of only $15 \%$, whereas the frequency of pollinator visits was linearly related to blossom cover up to $30 \%$. Higher numbers of flowering plant species led to a strong increase of the temporal stability in the frequency of pollinator visits.

In conclusion, grasslands with high numbers of flowering plant species and moderate blossom cover enhance and stabilize flower visitation, and thereby, effective pollination and plant reproduction.
\end{abstract}

\title{
Introduction
}

Pollinators provide a major ecosystem service through their key role in the reproduction process of most plant species (Burd 1994; Fontaine et al. 2006, Klein et al. 2007). Because a loss in plant-pollinator interactions can lead to parallel declines of plant species and their associated pollinators (Biesmeijer et al. 2006), understanding plant-pollinator community interactions is critical for the conservation of biodiversity.

Enhanced plant species richness has been hypothesized to promote richness of pollinators because of plant species-specific pollinator preferences and a better pollen and nectar resource availability over space and time (Linsley 1958, Eickwort 1980, Hegland and Totland 2005, Fontaine et al. 2006, Ghazoul 2006, Blüthgen et al. 2007, Kwaiser and Hendrix 2007). Increases in plant diversity have been shown to reduce the variability of pollinator population densities over time (Ghazoul 2006), indicating a higher dynamic stability of the pollinator community, thereby reducing the extinction risk. Enhanced pollinator richness should also increase the functional redundancy, so that potential extinctions may be compensated by remaining species (Yachi and Loreau 1999, Zamora 2000). 
In addition to species richness, floral abundance is another important variable structuring pollinator communities (e.g. Potts et al. 2003, 2006). Greater floral abundance means higher resource availability for pollinators, which may also contribute to dynamic stability.

Several studies have shown the great impact of plant species richness and floral abundance on pollinator communities (Steffan-Dewenter and Tscharntke 2001, Potts et al. 2003, Fontaine et al. 2006, Ghazoul 2006, Potts et al. 2006, Holzschuh et al. 2007), but in these studies differences in plant species richness were mostly the result of differences in intensity of land use, making it difficult to attribute changes in plant-pollinator interactions directly to differences in plant diversity. Intensive land management often change plant community composition and reduces plant species richness, while fertilization and irrigation may increase flower size, leading to a higher quality of nectar and pollen (Spaethe et al. 2001, Thompson 2001, Cartar 2004, Lau and Stephenson 1994), affecting pollinators (Cartar 2004). These examples demonstrate the difficulties in disentangling the effects of plant species richness, plant community composition and other habitat variables on the structure of pollinator communities.

We studied the relationship between plant and pollinator richness, frequency of pollinator visits, and dynamic stability, using a large-scale experimental manipulation of plant species richness. Plant species composition was randomised in the sown experimental plots to avoid confounding effects of community structure (e.g. species identity). This small-scale mosaic in plant species richness allowed pollinator species to select preferred plots which were well within their foraging ranges (Steffan-Dewenter et al. 2002; Westphal et al. 2003; Greenleaf et al. 2007). We focused on the two common social pollinators honey bees and bumble bees, which are polyphagous and have large foraging ranges (Eickwort and Ginsberg 1980, Westphal et al. 2006, Greenleaf et al. 2007). We also studied solitary bees (non-eusocial bees), many of which are specialized with respect to flower use (Eickwort and Ginsberg 1980), and hover flies, some of which are specialized and others generalized (Haslett 1989).

The general aim of our study was to analyze the influence of plant species richness or the number of flowering plant species, respectively, and blossom cover on pollinator species richness and the frequencies of pollinator visits. In particular, we explored:

(1) How the number of flowering plant species, blossom cover and plant species identity are related to pollinator species richness and the frequency of pollinator visits;

(2) The importance of the number of flowering plant species and blossom cover to different pollinator guilds, i.e. bumble bees, honey bees, solitary bees and hover flies; 
(3) The relationship between the number of flowering plant species and the dynamic stability (temporal variability) of pollinator flower visits.

\section{Materials and Methods}

\section{Study area and experimental design}

The Jena Experiment is located in the north of Jena, Germany, on the floodplain of the river Saale $\left(50^{\circ} 55^{\prime} \mathrm{N}, 11^{\circ} 35^{\prime} \mathrm{E} ; 130 \mathrm{~m}\right.$ above sea level) and was established in 2002 . The site was an arable field for the 40 years before the experiment started and thus was strongly fertilized over recent decades to increase crop productivity, but no fertilizer was added during the experimental period. Plots were mowed every June and September, a management regime used in meadows designed for intensive hay production. To maintain the sown species diversity level we weeded all plots every April and July.

The main experiment comprises 82 plots, each of $400 \mathrm{~m}^{2}$ area, with six levels of plant species richness $(1,2,4,8,16$, and 60 species). Species used in monocultures and mixtures were selected randomly from a species pool of 60 common grassland species (see Roscher et al. 2004 for species list). Monocultures, 2-species mixtures, 4-species mixtures and 8-species mixtures are represented with 16 replicates each, 16-species mixtures with 14 replicates and the 60 -species mixtures with 4 replicates. The $20 \mathrm{~m} \times 20 \mathrm{~m}$ plots were grouped into four blocks (randomized complete block design) along abiotic gradients reflecting distance to the river Saale (mainly soil sand content; Roscher et al. 2004), and diversity treatments were assigned equally within blocks. For our study we chose all plots but nine that contained only grasses, i.e., 73 plots.

\section{Pollinator observations}

For observations of pollinators we used a quadrat of $80 \mathrm{~cm} \times 80 \mathrm{~cm}$ within each $20 \mathrm{~m} \times 20 \mathrm{~m}$ plot. In 2005 we observed on 24-25 May and 15-16 June, before the first mowing in late June, and again on 18-19 August, after mowing. In 2006 we observed on 6-9 June and 17-18 June, before the first mowing, and again on 1-5 August. This resulted in 438 observations (73 plots $\times 2$ years $\times 3$ periods per year $=438$ ). Observations were only conducted on sunny days (at least $18^{\circ} \mathrm{C}$, to have similar insect activity) with no or little wind $(<2 \mathrm{~m} / \mathrm{s})$ between 0900 and 1700 hours. Observations within a block were carried out within two days, so weather conditions would be similar within blocks. The sequence of plot observations was not correlated with plant richness level within plots. 
We observed pollinating insects for 36 minutes in each plot $(2$ years $\times 3$ periods per year $\times 6$ minutes $=36$ minutes per plots). We identified pollinators directly to genus or morphospecies in the field. We tallied species numbers and frequencies of pollinator visits and also the plant species visited by each pollinator individual. We define the frequency of pollinator visits as the number of flower visits per plot during the observation period. Pollinators were grouped into honey bees, solitary bees, bumble bees, and hover flies. We define solitary bees as all non eu-social bees. After each observation period we collected all unknown species for further identification in the laboratory, and were thus able to identify all Hymenoptera and hover flies to species level. We morphotyped and pooled the remaining pollinators of the insect orders Lepidoptera, Coleoptera and Diptera (except the hover flies) into one group ("remaining pollinators") for analyses.

After each observation period we tallied the number of flowering plant species within the $80 \mathrm{~cm} \times 80 \mathrm{~cm}$ observation area and estimated the blossom cover $(\%)$ of each flowering plant species as a percentage of the total area.

\section{Statistical analyses}

We analysed whether pollinator species richness data were close to species saturation using EstimateS software ver. 8 (Colwell 2006). All plots of one plant species richness level were summarized and the abundance-based coverage estimator (ACE) was calculated with 500 randomizations to calculate percentage species saturation.

Our observation data included an excess of zeroes (no pollinators observed), which is usual for such data. Therefore standard parametric statistical models were not appropriate. We instead applied a so called zero-inflated Poisson model (Lambert 1992, Cunningham and Lindenmayer 2005) to describe pollinator species richness and the frequency of pollinator visits. In this approach the distribution of the response variable is modelled as a mixture of a Poisson and a Bernoulli distribution. The Bernoulli distribution models the proportion of extra zeroes which may depend on covariates. We modelled this proportion of extra zeroes as dependent on plant species richness.

Preliminary studies in 2004 showed a high attractiveness of the three legume species Onobrychis viciifolia Scop., Medicago varia Martyn and Lotus corniculatus L. and the herbaceous species Knautia arvensis (L.) Coult., Leucanthemum vulgare Lam. and Crepis biennis L.. We summarized these six species in a variable "presence of attractive plants".

We fitted a series of hierarchical models including the block, the number of flowering plant species per plot, the blossom cover $(\%)$, and the presence of attractive plants as independent 
variables. Response variables were pollinator species richness and the frequency of all pollinator visits, as well as species richness and frequency of visits of bumble bees, solitary bees, honey bees and hover flies. As further dependent variables we chose the number of pollinator species and the frequency of pollinator visits per resource unit per observation period. Here a resource unit corresponds to an area of flowers covering $1 \mathrm{~m}^{2}$ and was calculated from the estimates of blossom cover we had for our observation plots $(80 \mathrm{x} 80 \mathrm{~cm})$. Starting from the constant null model we added covariables sequentially. The statistical significance of model improvement was assessed using likelihood ratio tests. Variables without significant influence were omitted in subsequent models. Relative performance of models was compared with Akaike's Information Criterion (AIC); those with smaller AIC values provide a more adequate description of the observed data. The model comparison was performed using the packages gnlm and rmutil of the statistical software R (R Development Core Team, Vienna Austria. http://www.R-project.org.).

For further analyses we used software Statistica ver. 6. Correlations between the predictor variables were analyzed using Spearman's rank correlations. The coefficient of variance (CV) in the frequency of pollinator visits was calculated as standard deviation/mean $\times 100$. We analyzed this inverse measure of temporal stability in linear regressions with the number of flowering plant species and pollinator species richness as explanatory variables.

\section{Results}

\section{Vegetation}

In both years, the number of flowering plant species was positively related to the number of sown plant species (Table 1; $\mathrm{n}=73$, Spearman's $\mathrm{R}=0.55, \mathrm{p}<0.001$ ). The percent blossom cover followed the same pattern $(n=73$, Spearman's $R=0.45, p=0,001)$. The strong correlation between the number of sown and flowering plant species, as well as the importance of flowering plants for pollinators, led us to use only the richness of flowering species in the following analyses. All analyses were done also with the number of sown plant species, showing the same results (data not shown). 
Table 1:

Overview of the different variables representing the vegetation across the plant species gradient of the Jena Experiment. All values are means across 2005 and 2006 ( \pm standard error).

\begin{tabular}{ccc}
\hline Sown plant species richness & Mean number of flowering plant species & Mean blossom cover (\%) \\
\hline Monocultures & $1 \pm 0$ & $3.0 \pm 0.9$ \\
2 species & $1.6 \pm 0.2$ & $5.7 \pm 1.3$ \\
4 species & $2.1 \pm 0.2$ & $7.2 \pm 2.2$ \\
8 species & $3.8 \pm 0.4$ & $9.3 \pm 2.4$ \\
16 species & $6.8 \pm 0.6$ & $9.4 \pm 2.0$ \\
60 species & $12.5 \pm 0.9$ & $15.1 \pm 2.3$ \\
\hline
\end{tabular}

\section{Pollinator community}

Altogether we counted 5722 flower visits during our 438 observation periods. Honey bees (Apis mellifera) were most abundant with 2824 visits $(49.4 \%)$, followed by bumble bees (genus Bombus) with 1673 visits (29.2\%), solitary bees with 233 visits (4.1\%), and hover flies with 93 visits (1.6\%). Altogether we observed 29 wild bee species from seven genera. The most frequent genera in both years were bumble bees, followed by solitary bees in the genera Lasioglossum and Andrena. Additionally, we identified ten hover fly species from seven genera. We did all analyses with original species data as the mean species saturation per plant- richness level was high $(84.62 \pm 10.7 \%)$.

32 of the 60 plant species of the experimental species pool (including sixteen grass species, which are not insect-pollinated), were visited by pollinators. Onobrychis viciifolia was the plant species with the highest pollinator-visitation rate (3430 visits), followed by Knautia arvensis (742 visits), and Medicago varia (552 visits). 22 species had visitation rates below one percent and the visitation rates of the remaining seven plant species reached from one to six percent. Eleven plots were not visited by any pollinator.

\section{Effects of the plant community on pollinator species richness}

The number of pollinator species was strongly positively affected by the number of flowering plant species (Table 2, Figure 1A). We also found higher numbers of pollinator species with increasing blossom cover (Table 2, Figure 1B). The number of flowering plant species, but not blossom cover, was related to bumble bee and solitary bee species richness (Table 2). The number of hover fly species was not influenced by any of the tested variables (number of flowering plant species, percent blossom cover and presence of attractive plant species). The number of pollinator species per resource unit $\left(1 \mathrm{~m}^{2}\right.$ of flowers) declined with increasing number of flowering plant species (Table 2, Figure 2) and with increasing availability of floral resources (blossom cover/plot, Table 2). 
Table 2:

Model selection for pollinator species richness and the frequency of pollinator visits. The table shows AIC values for models including different predictor variables; lower values of AIC indicate better model fits. Variables were added sequentially, and each model was compared to the one in the previous column or the one that contained the last significant variable. Predictor variables are identity of the experimental block, number of flowering plant species/ plot, blossom cover of the observed plot (\%), and presence of attractive plant species. The second row shows the degrees of freedom (df) for the null model and for each of the predictor variables. $*=\mathrm{p}<0.05 ; * *=\mathrm{p}<0.01 ; * * *=\mathrm{p}<0.001$.

\begin{tabular}{|c|c|c|c|c|c|}
\hline Predictor variable & $\begin{array}{c}\text { Null } \\
\text { model }\end{array}$ & +Block & $\begin{array}{c}\text { +Number of flowering } \\
\text { plant species }\end{array}$ & $\begin{array}{c}\text { +Blossom cover/ } \\
\text { plot }(\%)\end{array}$ & $\begin{array}{c}\text { +Presence of attractive } \\
\text { plant species }\end{array}$ \\
\hline Degrees of freedom & 70 & 3 & 1 & 1 & 1 \\
\hline Number of pollinator species & 409 & 412 & $376 * * *$ & $360^{* * *}$ & 361 \\
\hline Number of bumble bee species & 211 & 216 & $198 * * *$ & 197 & 199 \\
\hline Number of solitary bee species & 185 & 189 & $175 * * *$ & 176 & 177 \\
\hline Number of hover fly species & 124 & 129 & 125 & 125 & 125 \\
\hline Frequency of pollinator visits & 6810 & $\mathbf{5 9 8 6}^{* * *}$ & $4901 * * *$ & $4233 * * *$ & $4225 * *$ \\
\hline Frequency of honey bee visits & 3268 & 2811 *** & $2645^{* * *}$ & $2337 * * *$ & $2292 * * *$ \\
\hline Frequency of bumble bee visits & 1914 & $1598 * * *$ & $1471 * * *$ & $1406^{* * * *}$ & $1402 *$ \\
\hline Frequency of solitary bee visits & 369 & $365^{*}$ & $354 * * *$ & 353 & $325 * * *$ \\
\hline Frequency of hover fly visits & 246 & $236^{* *}$ & 238 & $205^{* * *}$ & 206 \\
\hline Frequency of pollinator visits/ $\mathbf{m}^{2}$ flowers & 1129 & 1131 & 1131 & 1128 & 1131 \\
\hline Number of pollinator species / $\mathbf{m}^{2}$ flowers & 849 & 851 & $841 * *$ & $795 * * *$ & $788 * *$ \\
\hline
\end{tabular}

\section{Effects of the plant community on the frequency of pollinator visits}

The overall frequency of pollinator visits was positively correlated with the number of flowering plant species (Figure 1C). Plots with one flowering plant species experienced around twenty flower visits per plot, while we found as many as 200 flower visits in the plots containing twelve flowering plant species. Such strong positive correlations were also found between blossom cover and the overall frequency of pollinator visits (Table 2, Figure 1D). The presence of attractive plant species exhibited also a positive effect on the overall frequency of pollinator visits (Table 2).

All predictor variables tested (the number of flowering plant species, percent blossom cover, presence of attractive plant species) had strong positive effects on the frequency of honey bees and bumble bees (Table 2). The visitation rate of solitary bees was positively influenced by the number of flowering plant species and the presence of attractive plant species, while the frequency of hover fly visits increased with increasing blossom cover. We also found a significant block effect on pollinator frequencies, possibly due to one block with high grass cover and low frequency of pollinator visits (Table 2).

We detected no correlations between the overall frequency of pollinator visits per resource unit and the tested explanatory variables number of flowering plant species, percent blossom cover, or the presence of attractive plant species (Table 2). 
A

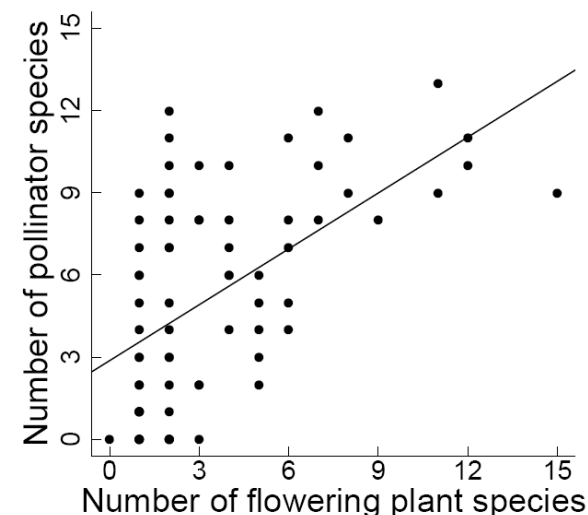

$\mathrm{C}$

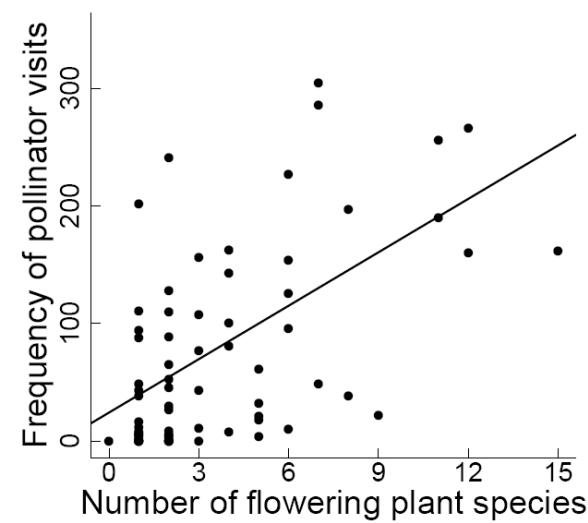

B

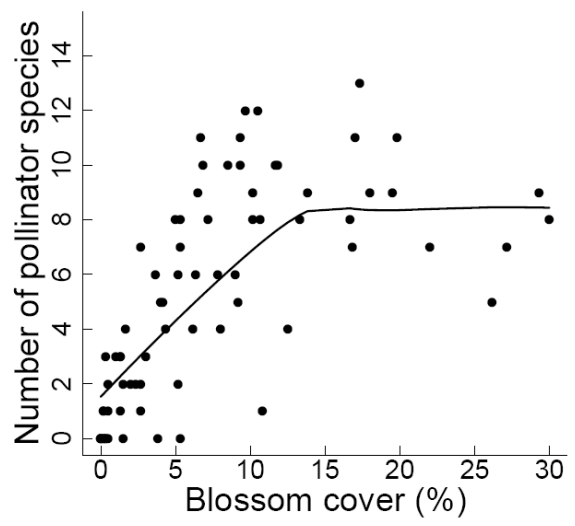

$\mathrm{D}$

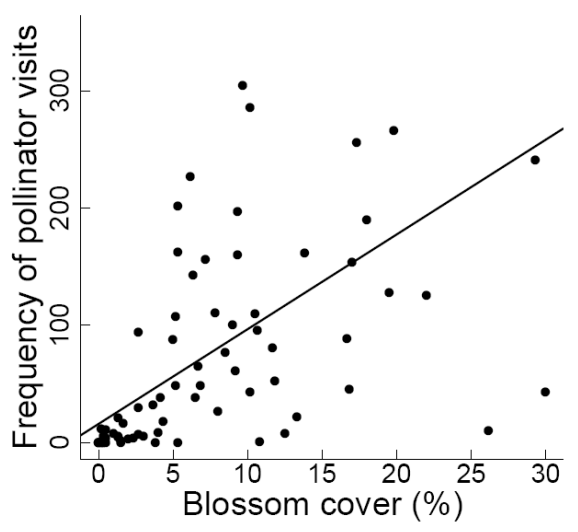

Figure 1: Effects of the number of flowering plant species and percent blossom cover on A) and B) the number of pollinator species and C) and D) the frequency of pollinator visits in 36min of observation in 2005 and 2006. The lines are the least-squares fit.

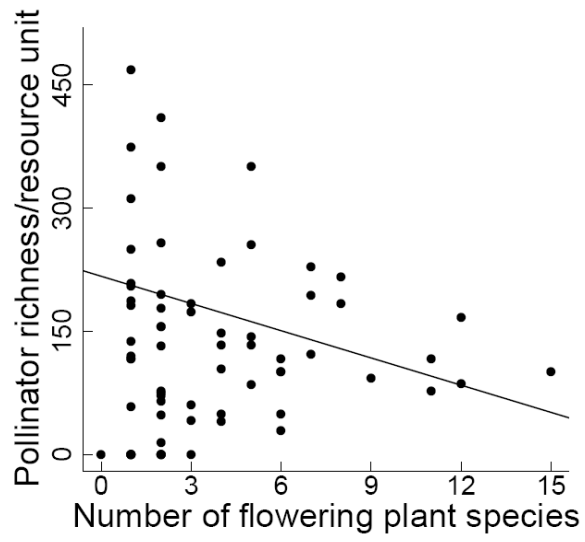

Figure 2:

Effects of the number of flowering plant species on the number of pollinator species/ resource unit $\left(\mathrm{m}^{2}\right.$ flowers). Other conventions follow Figure 1. 


\section{Effects of plant species richness on the temporal variability of pollinator visits}

Temporal variability in the frequency of pollinator visits across all six observational periods per plot declined with increasing number of flowering plant species (Figure $3 \mathrm{~A} ; \mathrm{F}_{1,60}=12.27$, $\mathrm{p}<0.001$ ), and pollinator species richness (Figure 3B; $\mathrm{F}_{1,60}=11.97, \mathrm{p}<0.001$ ). Patterns were similar in each year for the number of flowering plant species $\left(2005: \mathrm{F}_{1,60}=15.41, \mathrm{p}<0.001\right.$; 2006: $\left.\mathrm{F}_{1,60}=4.89, \mathrm{p}=0.032\right)$ and for pollinator species richness $\left(2005: \mathrm{F}_{1,60}=32.78, \mathrm{p}<\right.$ $\left.0.001 ; 2006: \mathrm{F}_{1,60}=46.89, \mathrm{p}<0.001\right)$.

A

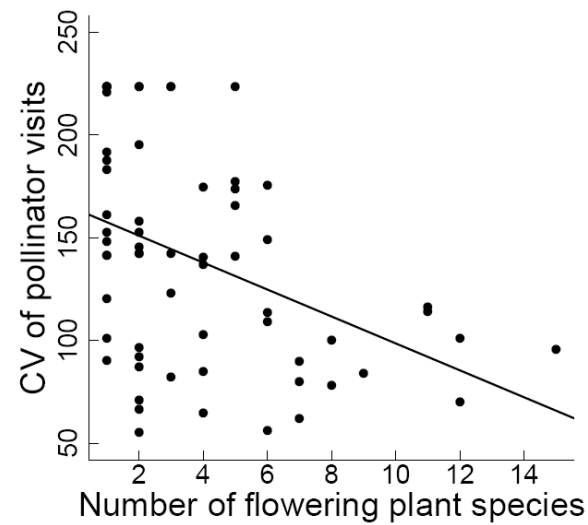

B

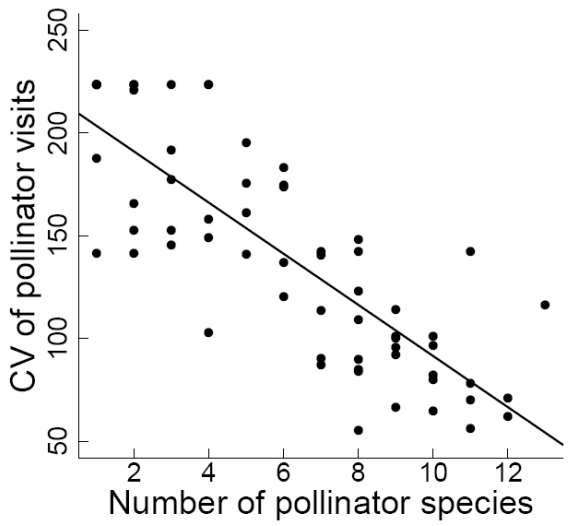

Figure 3:

Effects of A) the number of flowering plant species and B) the pollinator species richness on the coefficient of variation $(\mathrm{CV})$ in the frequency of pollinator visits. Other conventions follow Figure 1.

\section{Discussion}

Results of this study showed that the number of flowering plant species was positively related to the pollinators' species richness, frequency of visits and dynamic stability. This effect held for the frequency of all three pollinator guilds (honey bees, bumble bees, solitary bees) and for the species richness of bumble bees and solitary bees.

The positive impact of the number of flowering plant species on pollinator species richness and overall frequency of pollinator visits may be explained by increasing floral resource heterogeneity (nectar and pollen), which increases attractiveness for many pollinator species seeking single and multiple resources ( Tscharntke et al. 1998, Potts et al. 2003, Ghazoul 2006). In successional fallows (Steffan-Dewenter and Tscharntke 2001) and wheat fields (Holzschuh et al. 2007), bee species richness increased with plant species richness, whereas bee abundance could be best explained by blossom cover. These findings contrast with the results of Hegland and Boeke (2006) who found no effects of plant species richness on 
pollinator species richness. These contrasting results may have been caused by confounding factors, which are usually associated with field studies. For example, plant richness is often related to changes in plant community structure, soil fertility and disturbance caused by landuse management. Hence, an experimental design like The Jena Experiment, with plant species richness being experimentally manipulated, is needed to draw reliable conclusions on the importance of plant species richness per se.

In addition to the richness of flowering plant species, the availability of food resources (blossom cover) was expected to show a strong impact on the pollinators, as found by Hegland and Boeke (2006). By analogy to the resource concentration hypothesis for herbivores (Root 1973), pollinator species richness and the frequency of pollinator visits should increase with increasing blossom cover. An alternative hypothesis is that abundant food resources lead to a dilution in pollinator density, which would predict a humped-shaped response of pollinators to blossom cover (as shown by Veddeler et al. 2006 for coffee farms). Our findings support a resource concentration hypothesis for pollinator frequency, but not richness, because we found a saturation effect with no changes in pollinator richness from $15 \%$ to $30 \%$ blossom cover. In contrast, the negative relation between blossom cover and the frequency of pollinator visits per resource unit $\left(1 \mathrm{~m}^{2}\right.$ of flowers) support the hypothesed dilution effect. Totland and Matthews (1998) suggested that the pool of available pollinators may be often saturated, based on their findings of a negative relationship between flower density and the visitation rates of pollinators.

Blossom cover affected the pollinator guilds differently in that the frequencies of the social pollinators (honey bees, bumble bees), but not solitary bees, increased with blossom cover. Further, blossom cover did not affect species richness of bumble bees and solitary bees, whereas the number of flowering plant species was closely related to all measures of the three bee guilds. This indicates that solitary bees are more sensitive to changes in plant richness than social bees, and that pollinator species number depends more on higher plant richness than do visitation frequencies. These findings support Westphal et al. (2003) in that social pollinator groups are more influenced by the amount of floral resources than by plant species richness, whereas solitary guilds need high plant diversity for species-rich communities. This difference may be due to the more generalized use of food plants by honey bees and bumble bees (Totland and Matthews 1998; Walther-Hellwig and Frankl 2000; Steffan-Dewenter et al. 2002).

With respect to the stability of pollinator visits, our results pertain to the longstanding diversity-stability debate (Pimm 1991, Naeem and Li 1997, McCann 2000, Loreau et al. 2003, 
Tilman et al. 2006). This debate began with Elton (1958) and MacArthur (1955), who assumed that diverse communities are more stable. The positive relationship between diversity and stability in our system may have been caused by the fact that plant diversity increases the probability of having more pollinator species that are less sensitive to changing floral resources (Naeem and Li, 1997; Naeem 1998). In addition, higher plant and thereby higher pollinator diversity may enhance functional redundancy of pollinator species, thereby stabilizing the frequency of flower visits (Zamora 2000). Both ideas reflect the insurance hypothesis of biodiversity by Yachi and Loreau (1999) in that more species in a functional group provide insurance in ever changing environments. Ghazoul (2006) argued that the positive impact of plant species richness on the dynamic stability of pollinators can have different reasons. Complementary attraction is one mechanism leading to maximal attraction of pollinators by a combined floral display, thereby dampening variability in pollinator dynamics (Rathcke 1988, Moeller 2004). This small-scale mechanism differs from the broadscale mechanism proposed by Moeller (2004) in which diverse floral communities diversify and stabilize pollinator communities by providing a more temporally continuous supply of floral resources. Both hypotheses provide a mechanistic understanding of higher stability in pollinator visitation and increased species richness of pollinators with increasing number of flowering plant species.

In conclusion, the number of flowering plant species and blossom cover, but not the identity of high-attractive plant species, enhanced pollinator species richness. High blossom cover of plants enhanced the frequencies of social bee species, which are known to exploit mass resources, but not solitary species, which appeared to be more structured by the heterogeneity of high plant species richness. Both species-rich and strongly flowering plant communities are important in grasslands to ensure high diversity and stability of pollinators. Vice versa, the conservation of species-rich pollinator communities is a basic requirement for the reproductive success and sustained stability of plant communities.

\section{Acknowledgements}

We thank the many people helping with the management of the Jena-Experiment, especially the field coordinator Alexandra Weigelt and the gardeners Steffen Eismann, Silke Hengelhaupt, Sylvia Junghans, Ute Köber, Katja Kunze, Gerlinde Kratzsch, Heike Scheffler, and Ulrike Wehmeier. The help during fieldwork by Sylvia Creutzburg, Michaela Knauer and Heike Baldeweg and all the helpers during the weeding campaigns is gratefully 
acknowledged. Christoph Scherber is gratefully acknowledged for his advice and Nick Waser, Christine Müller, Rachael Winfree and one anonymous referees for helpful comments on the manuscript. Lora Morandin is gratefully acknowledged for final language-editing. The Jena Experiment is funded by the Deutsche Forschungsgemeinschaft, with additional support from the Friedrich Schiller University of Jena and the Max Planck Society.

\section{References}

Biesmeijer, J.C. , S. P. M., Reemer, M., Ohlemuller, R., Edwards, M., Peeters, T., Schaffers, A. P., Potts, S. G., Kleukers, R., Thomas, C. D., Settele, J. and Kunin, W. E. 2006. Parallel declines in pollinators and insect-pollinated plants in Britain and the Netherlands. - Science $313: 351-354$.

Blüthgen, N. Menzel, F., Hovestadt, T., Fiala, B. and Bluthgen, N. 2007. Specialization, constraints, and conflicting interests in mutualistic networks. - Current Biology 17: 1-6.

Burd, M. 1994. Bateman's principle and plant reproduction - the role of pollen limitation in fruit and seed set. - Botanical Review 60: 83-139.

Cartar, R.V. 2004. Resource tracking by bumble bees: responses to plant-level differences in quality. - Ecology 85 (10): 2764-2771.

Cunningham, R. B. and Lindenmayer, D. B. 2005. Modeling count data of rare species: some statistical issues. - Ecology 86: 1135-1142.

Eickwort, G.C. and Ginsberg, H.S. 1980. Foraging and mating behavior in Apoidea. - Ann. Rev. Entomol. 25: 421-46.

Elton, C.S. 1958. Ecology of invasions by animals and plants. Chapman \& Hall.

Fontaine, C. Dajoz, I., Meriguet, J. and Loreau, M. 2006. Functional diversity of plantpollinator interaction webs enhances the persistance of plant communities. - PLoS Biol 4: 129-135.

Ghazoul, J. 2006. Floral diversity and the facilitation of pollination. - Journal of Ecology 94: 295-304.

Greenleaf, S.S. Williams, N. M., Winfree, R. and Kremen, C. 2007. Bee foraging ranges and their relationship to body size. - Oecologia 153: 589-596.

Haslett, J.R. 1989. Interpreting patterns of resource utilization: randomness and selectivity in pollen feeding by adult hoverflies. - Oecologia 78: 433-442.

Hegland, S.J. and Totland, O. 2005. Relationships between species' floral traits and pollinator visitation in a temperate grassland. - Oecologia 145: 586-594. 
Hegland, S.J. and Boeke, L. 2006. Relationships between the density and diversity of floral resources and flower visitor activity in a temperate grassland community. - Ecological Entomology 31: 532-538.

Holzschuh, A. Steffan-Dewenter, I., Kleijn, D. and Tscharntke, T. 2007. Diversity of flowervisiting bees in cereal fields: effects of farming system, landscape composition and regional context. - Journal of Applied Ecology 44: 41-49.

Klein, A.M. Vaissiere, B. E., Cane, J. H., Steffan-Dewenter, I., Cunningham, S. A., Kremen, C. and Tscharntke, T. 2007. Importance of pollinators in changing landscapes for world crops. - Proceedings of the Royal Society B-Biological Sciences 274: 303-313.

Kwaiser, K. S. and Hendrix, S. D. 2008. Diversity and abundance of bees (Hymenoptera : Apiformes) in native and ruderal grasslands of agriculturally dominated landscapes. Agriculture Ecosystems \& Environment 124: 200-204.

Lambert, D. 1992. Zero-inflated Poisson regression, with an application to defects in manufacturing. - Technometrics 34: 1-14.

Lau, T. C. and Stephenson, A. G. 1994. Effects of soil-phosphorus on pollen production, pollen size, pollen phosphorus-content, and the ability to sire seeds in Cucurbita-Pepo (Cucurbitaceae). - Sexual Plant Reproduction 7: 215-220.

Linsley, E.G. 1958. The ecology of solitary bees. - Hilgardia 27: 543-599.

Loreau, M. Mouquet, N. and Gonzalez, A. 2003. Biodiversity as spatial insurance in heterogeneous landscapes. - Proceedings of the National Academy of Sciences of the United States of America 100: 12765-12770.

MacArthur, R.H. 1955. Fluctuations of animal populationsand a measure of community stability. - Ecology 36: 533-536.

McCann, K. S. 2000. The diversity-stability debate. - Nature 405: 228-233.

Moeller, D.A. 2004. Facilitative interactions among plants via shared pollinators. - Ecology 85: 3289-3301.

Naeem, S. 1998. Species redundancy and ecosystem reliability. - Conserv. Biol. 12: 39-45.

Naeem, S. and Li, S.B. 1997. Biodiversity enhances ecosystem reliability. - Nature 390: 507509.

Pimm, S. 1991. The balance of nature? Ecological issues in the conservation of species and communities. University of Chicago Press, Chicago.

Potts, S.G. Vulliamy, B., Dafni, A., Ne'eman, G. and Willmer, P. 2003. Linking bees and flowers: how do floral communities structure pollinator communities? - Ecology 84: 26282642. 
Potts, S.G. Petanidou, T., Roberts, S., O'Toole, C., Hulbert, A. and Willmer, P. 2006. Plantpollinator biodiversity and pollination services in a complex Mediterranean landscape. Biological Conservation 129: 519-529.

Rathcke, B. 1988. Interactions for pollination among coflowering shrubs. - Ecology 69: 446457.

Root, R.B. 1973. Organization of a plant-arthropod association in simple and diverse habitats - fauna of collards (Brassica oleracea). - Ecological Monographs 43: 95-120.

Roscher, C. , J., Baade, J., Wilcke, W., Gleixner, G., Weisser, W. W., Schmid, B. and Schulze, E. D. 2004. The role of biodiversity for element cycling and trophic interactions: an experimental approach in a grassland community. - Basic and Applied Ecology 5: 107121.

Spaethe, J. Tautz, J. and Chittka, L. 2001. Visual constraints in foraging bumblebees:

flower size and color affect search time and flight behavior. - Proceedings of the National Academy of Sciences of the United States of America 98: 3898-3903.

Steffan-Dewenter, I. and Tscharntke, T. 2001. Succession of bee communities on fallows. Ecography 24: 83-93.

Steffan-Dewenter, I. Münzenberg, U., Bürger, C., Thies, C. and Tscharntke, T. 2002. Scaledependent effects of landscape context on three pollinator guilds. - Ecology 83: 1421-1432.

Thompson, J.D. 2001. How do visitation patterns vary among pollinators in relation to floral display and floral design in a generalist pollination system? - Oecologia 26: 386-394.

Tilman, D. Reich, P. B. and Knops, J. M. H. 2006. Biodiversity and ecosystem stability in a decade-long grassland experiment. - Nature 441: 629-632.

Totland, O. and Matthews, I. 1998. Determinants of pollinator activity and flower preference in the early spring blooming Crocus vernus. - Acta Oecologica 19: 155-165.

Tscharntke, T. Gathmann, A. and Steffan-Dewenter, I. 1998. Bioindication using trap-nesting bees and wasps and their natural enemies: community structure and interactions. - Journal of Applied Ecology 35: 708-719.

Veddeler, D. Klein, A. M. and Tscharntke, T. 2006. Contrasting responses of bee communities to coffee flowering at different spatial scales. - Oikos 112: 594-601.

Walther-Hellwig, K. and Frank1, R. 2000. Foraging habitats and foraging distances of bumblebees Bombus spp. (Hymenoptera, Apidae), in an agricultural landscape. - Journal of Applied Entomology 124: 299-306.

Westphal, C. Steffan-Dewenter, I. and Tscharntke, T. 2003. Mass flowering crops enhance pollinator densities at a landscape scale. - Ecology Letters 6: 961-965. 
Westphal, C. Steffan-Dewenter, I. and Tscharntke, T. 2006. Bumblebees experience landscapes at different spatial scales: possible implications for coexistence. - Oecologia 149: 289-300.

Yachi, S. and Loreau, M. 1999. Biodiversity and ecosystem productivity in a fluctuating environment: the insurance hypothesis. - Proceedings of the National Academy of Sciences of the United States of America 96: 1463-1468.

Zamora, R. 2000. Functional equivalence in plant-animal interactions: ecological and evolutionary consequences. - Oikos 88: 442-447. 


\section{CHAPTER 4}

PLANT DIVERSITY INCREASES FLORAL SPECIALIZATION IN PLANTPOLLINATOR INTERACTION WEBS

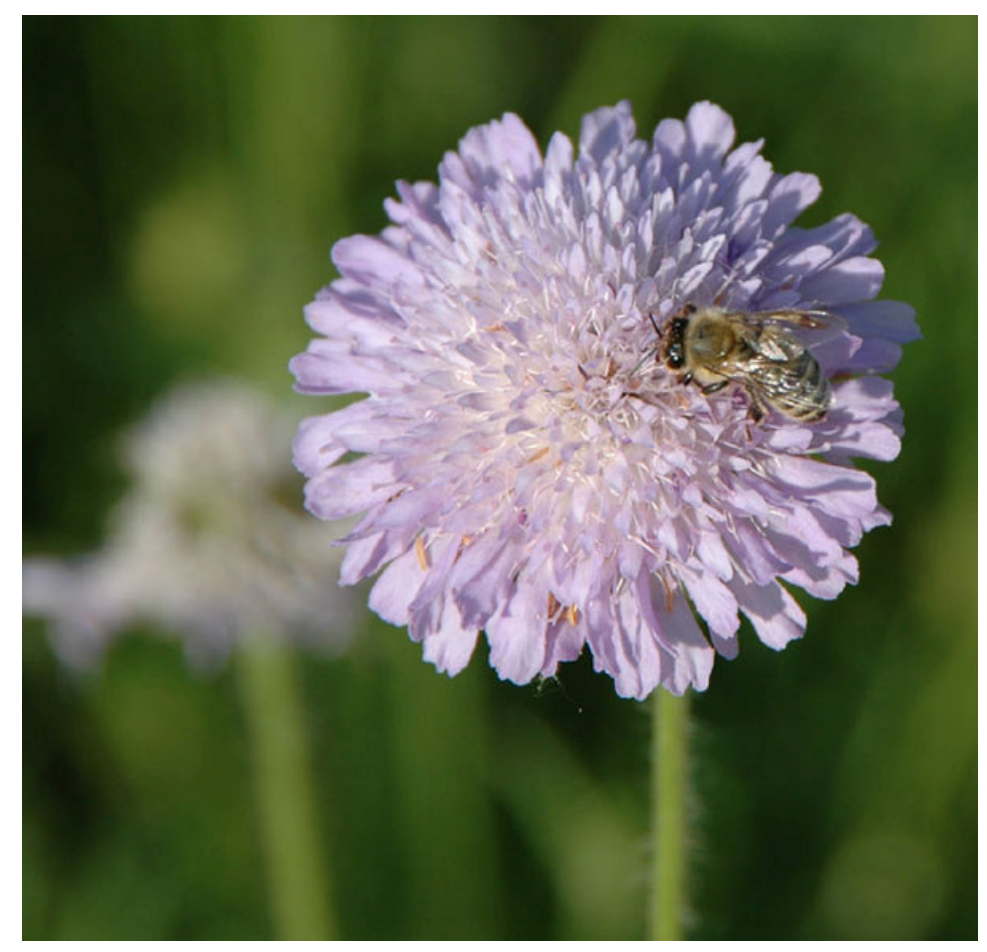




\begin{abstract}
Anthropogenic landscape changes have caused losses in functional biodiversity of plants and associated animals. Although most plants benefit from pollen vectors, little information exists about how plant diversity structures the interactions between plants and their pollinators. The structure of such networks can be characterized by interaction diversity and frequency and holds information about specialization, effectiveness of pollinator's resource use, pollination success, and ecosystem stability. We analyzed 52 grassland plant-pollinator networks along a gradient of plant species richness. Linkage density increased, whereas network connectance decreased with higher floral diversity, suggesting higher ecosystem stability of mutualistic networks against disturbances with higher floral diversity. Floral resource specialization of solitary bees increased with increasing floral diversity, and honeybees showed the same patterns with marginal significance. Higher floral resource specialization of pollinators should result in enhanced pollinator effectiveness, underlining the need to conserve diverse grasslands for maintenance of pollinator diversity and associated pollination services.
\end{abstract}

\title{
Introduction
}

Pollination is a key ecosystem process, resulting from the relationship between plants and animals. In such a network, pollinators interact with plants by visiting flowers to obtain protein-rich food and the plants in turn obtain pollen for successful reproduction. Insects, particularly bees, are the most important providers of pollen for plants (Burd 1994, Fontaine et al. 2006, Klein et al. 2007). Plant reproduction may not only be influenced by the number and density of pollinating species, but may depend also on the number and type of interactions between plants as the primary producers and pollinators as the primary consumers.

Although, around 17000 bee species exist worldwide (Michener 2000), today in many parts of the world, the bee community is often dominated by few species or even a single domesticated bee, the honeybee Apis mellifera (Committee on the Status of Pollinators in North America 2007, Forup et al. 2007). Currently, we face unpredictable global losses of high numbers of honeybee colonies through unexplained phenomenon called 'Colony Collapse Disorder' (CCD) (Stokstad 2007). Concomitant with declining honeybee colonies, adequate pollination services, especially to crop plants, may be increasingly at risk (Winfree et al. 2007), raising concern about a global pollinator decline (Committee on the Status of Pollinators in North America 2007). When honeybees are unable to provide the required service to plants, it is most important to understand how alternative pollinators interact with 
their plant mutualists. In this context, analyses of quantified plant-pollinator webs, examining the factors enhancing pollinator diversity and plant-pollinator interactions, may help to evaluate the contribution of alternative pollinators to serve plants with compatible pollen to set fruits.

Quantitative interaction webs and their metrics such as qualitative linkage density (trophic links/ species) and connectance (realized trophic links/ possible trophic links) or floral resource specialization indices hold important information, not only for coevolution theories, but also for ecosystem stability (e.g. May 1972, Jordano 1987). Food web theory predicts a decline in the complexity (lower interconnectance between the parties) of biotic interactions with decreasing species diversity and abundance, which makes a system more sensitive to extinctions of important key species or elements (lower ecosystem stability against disturbance and species extinction) shown for example by low values of linkage density (Melian and Bascompte 2002, Ives and Cardinale 2004). Further, the degree of pollinator resource specialization within a network may be an indicator of the effectiveness of the pollination service provided (Montoya et al. 2006), because higher resource specialization implies a higher floral constancy, which in turn may lead to a better pollination benefit (Larsson 2005, Eickwort and Ginsberg 1980).

Recently, methods have been developed to allow the quantification of pollinator resource specialization (Blüthgen et al. 2006). Here a network-wide measure of specialization is given by H' (standardized two-dimensional entropy), and a species or guild measure of specialization can be calculated by d' (standardized Kullback-Leibler distance), thereby not beeing mathematically related to network size (Blüthgen et al. 2006, Blüthgen et al. 2007) (total number of species).

Bee pollinators greatly differ in their feeding niches and the majority of pollinating species are polylectic and forage on pollen or nectar of many different plant species (Eickwort and Ginsberg 1980). Oligolecty, where species restrict pollen to one or a few related plant species, is well represented in the bee families Colletidae, Andrenidae, Megachilidae and Anthophoridae and rare in the Apidae, which contains the greatest density of social taxa of any bee family (including honeybees and bumblebees) (Eickwort and Ginsberg 1980).

Many real-world studies have investigated mutualistic networks (e.g. Blüthgen et al. 2006, Memmott 1999, Memmott et al. 2004, Ollerton and Cranmer 2002, Vazquez and Aizen 2003) by analysing existing differences in plant composition and floral diversity. However, these studies did not control for additional influencs occuring in natural ecosystems, such as differences in plant composition and floral diversity, and failed to separate the pollinator 
community response to vegetation structure, plant diversity or floral variation. For example, floral diversity as a variable in agroecosystems can be blurred by secondary effects of management like differences in soil nutrients due to fertilization, which in turn may impact on attractiveness for pollinators (e.g. changes in flower size, nectar quality, pollen quality) (Spaethe et al. 2001, Thompson 2001, Cartar 2004).

In this study, we analyzed the structure and the specificity of 52 plant-pollinator interaction webs along an experimental gradient of floral diversity, thereby excluding secondary effects of natural ecosystems. We used replicated experimental grassland plots, where plant species richness was artificially manipulated and species composition was randomly selected out of a species pool of 60 grassland species. Our intention was to answer the following questions: (i) How does floral diversity influence the structure of plant-pollinator webs? (ii) How does floral diversity affect the degree of network organization and the specialization of plants and pollinators? (iii) Do different pollinator guilds (honeybees, bumblebees, solitary bees) react similarly to increased floral diversity?

\section{Materials and Methods}

Study site and experimental design

The experimental study site is located in the north of Jena, Germany, on the floodplain of the river Saale $\left(50^{\circ} 55^{\prime} \mathrm{N}, 11^{\circ} 35^{\prime} \mathrm{E}\right.$; $130 \mathrm{~m}$ above sea level) and was established in 2002 . The site was used as an arable field before the sowing of the experimental species and has been strongly fertilized over the last decades. The main experiment comprises 82 plots with six levels of plant species richness $(1,2,4,8,16,60)$. For any combination of plant species richness level, the particular species mixtures were randomly selected from a species pool of 60 common grassland species (Roscher et al. 2004). Monocultures, 2-species mixtures, 4species mixtures and 8-species mixtures are represented with 16 replicates each, 16-species mixtures with 14 replicates and the 60 -species mixtures with 4 replicates. For our observation of plant-pollinator interaction webs we chose a quadrat of $80 \times 80 \mathrm{~cm}$ within $7320 \times 20 \mathrm{~m}$ plots (we excluded grass plots), thereby having always the same position within the plot. All plots are mown twice per year to manage them as extensive meadows. To maintain the sown species diversity level, we weeded all plots regularly twice per year in April and July.

\section{Flower-visiting species}

In 2005 and 2006, we observed flower-visiting insects three times per year, beginning in May and ending in September. Observations were only made on sunny days (at least $18^{\circ} \mathrm{C}$ and 
$70 \%$ sunshine) with low wind $(<2 \mathrm{~m} / \mathrm{s})$ between 9 am and $5 \mathrm{pm}$. We performed the observations for $6 \mathrm{~min}$ at each plot, twice before the first mowing, and once after the first mowing (mowing periods: 13- 26 June 2005 and 15- 23 June 2006) and recorded the visitation frequency of flower visitors per plant species. Visitation frequency was the number of flower visits by pollinator individiuals in the given time period. In 2005, first recordings were done on 24 and 25 May, the second on 15 and 16 June, and the third on 18 and 19 August 2005. Observations in 2006 were carried out between 6 and 9 June, 17 and 18 June, and 1 and 5 of August 2006.

Where possible, we identified insects to species level already in the field; otherwise they were morphotyped and collected after the observation period for further identification in the laboratory. Bees were the dominant pollinators in our plots and were grouped into three different pollinator guilds, which are honeybees, bumblebees and solitary bees. We defined solitary bees as all non-eusocial bees.

\section{Plant species}

We identified all flowering plant species in every plot at each visit (Roscher et al. 2004). Not all plant species were flowering at all times, which led to a lower floral diversity than plant species diversity. We noted the species identity of each visited flower and we estimated the blossom cover of each flowering plant species as percent cover/ observed plot.

\section{Analyses}

As pollinator sampling is unlikely to be complete we measured whether the data of pollinator species richness were close to species saturation curve using the EstimateS software ver. 8 (Colwell 2006). We summarized all plots of one plant species richness level and calculated the abundance-based coverage estimator ACE with 500 randomizations to calculate percentage species saturation.

Quantitative visitation webs were drawn by a program written in Microsoft Visual Basic by Roland Schmid. We sorted plant species of each plot by their blossom covers, numbered from the highest blossom values to the lowest (1-8). Within one plant diversity level we finally summarized the blossom values of all plants with the same numbers, resulting in six pooled quantitative visitation webs.

Data were square-root or log transformed if Q-Q plots showed deviations from normality. Missing data were excluded from the analyses. 
In order to compare the interaction webs along the gradient of floral diversity, we calculated the following metrics for each plant-pollinator interaction web:

(1) linkage density [LD]

(2) connectance $[\mathrm{C}]$

(3) number of observed pollinator species per visited plant species

(4) number of observed flower visits per visited plant species.

We calculated these four metrics for 52 plots. For the remaining plots we found fewer than two pollinator species during our observation periods.

Linkage density is the number of trophic interactions divided by the number of species:

$$
L D=l / s
$$

where $l$ is the number of observed linkages and $s$ the total number of species associated to the plant-pollinator web.

Connectance was calculated as the fraction of realized trophic interactions in the web (10):

$$
C=l / p * a
$$

where $p$ is the number of plant species and $a$ the number of animal (pollinator) species. The number of links is counted as present or absent and does not involve variation in link strength. Hence results could vary with sampling intensity. To address this problem, we calculated the following quantitative metrics (Blüthgen et al. 2006) for each web containing at least two plant and two pollinator species (29 plots):

(1) two dimensional Shannon entropy $\left[\mathrm{H}_{2}{ }_{2}\right]$

(2) weighted Kullback-Leibler distance for all pollinators $\left[<\mathrm{d}^{\prime}{ }_{\text {poll }}>\right]$ and all plants $\left[<\mathrm{d}^{\prime}\right.$ plant $\left.>\right]$

(3) Kullback- Leibler distance for honeybees (27 plots; [d' $\left.{ }_{A p i s}\right]$ ), bumblebees (26 plots; [d' ${ }_{\text {Bombus }}$, solitary bees (24 plots; [d' $\left.{ }_{\text {bees }}\right]$.

The species specialization indices ( $d$ ' and $<d^{\prime}>$ ) include interaction frequency as a measure of link strength and are scaled independently and largely insensitive to sampling intensity (Blüthgen et al. 2007). The degree of specialization of each web was defined as the deviation of an expected distribution of interactions (calculated by the standardized two-dimensional entropy $\mathrm{H}_{2}{ }_{2}$ ). Individual species' specialization (evaluated by standardized Kullback-Leibler distance, d') can be interpreted as deviation of interaction frequencies from a null model, which assumes that all species interact with their partners in relation to their total frequencies. The species' specialization index ranges from 0 to 1.0 , from the most generalized to the most specialized case. Specialization indices where calculated online by a program "Montecarlo statistics on RxC matrices" written by Nils Blüthgen (http://nils.mib.man.ac.uk/ nils/stat/). 
We used a linear model (LM) to investigate the effect of the number of flowering plant species on the structure of plant-pollinator webs and found a strong correlation between the sown and the flowering plant species richness (Table 1; $\mathrm{n}=52$, Spearmans $\mathrm{R}=0.55, \mathrm{p}<0.001$ ), which led to the use of just one of these metrics, flowering richness, for all analyses.

At the network level, we tested linkage density, connectance and the standardized twodimensional entropy $\left(\mathrm{H}_{2}{ }_{2}\right)$ with floral abundance (percent blossom cover per subplot), and the number of flowering plant species (in this order) as response variables in a GLM with Type I sequential sums of squares. For the analyses of linkage density and connectance we added the network size as a further independent variable, entering the model first. With the same linear model we tested the ratio between: i) observed pollinator species/ visited plant species and ii) flower visits/ per visited plant species. For analyzing specialization at the guild and species level, we tested the weighted Kullback-Leibler distance of pollinators $\left[<\mathrm{d}^{\prime}\right.$ poll $\left.>\right]$ and plant species $\left.\left[<\mathrm{d}_{\text {plant }}\right\rangle\right]$, and the specialization indices of solitary bees [d'bees], bumblebees $\left[\mathrm{d}_{\text {Bombus }}\right]$ and honeybees $\left[\mathrm{d}^{\prime}{ }_{\text {Apis }}\right]$ with floral abundance and floral diversity as response variables. For analysing the Kullback-Leibler distance of several pollinator guilds we used the number of involved pollinator guilds as an additional response variable, entering the model first.

The linear modelling was performed using the statistical software R (R Development Core Team, Vienna Austria. http://www.R-project.org.).

Table 1:

Overview of the different variables associated with changes in plant species richness across the gradient of the Jena Experiment (observed over two years in 2005 and 2006). The web metrics refer to the density of links, connectance and network specialization of pooled plant-pollinator webs.

\begin{tabular}{|c|c|c|c|c|c|}
\hline Sown diversity & $\begin{array}{c}\text { Mean floral } \\
\text { diversity }\end{array}$ & $\begin{array}{c}\text { Number of visited plant } \\
\text { species }\end{array}$ & $\begin{array}{c}\text { Mean linkage } \\
\text { density }\end{array}$ & $\begin{array}{c}\text { Mean network } \\
\text { connectance }\end{array}$ & $\begin{array}{r}\text { Mean network } \\
\text { specialization }\end{array}$ \\
\hline Monocultures & 1 & 1 & 0.78 & 1 & - \\
\hline 2 species & 1.7 & 2 & 0.80 & 0.78 & 0.70 \\
\hline 4 species & 2.4 & 2 & 0.82 & 0.88 & 0.27 \\
\hline 8 species & 4.1 & 5 & 0.77 & 0.61 & 0.69 \\
\hline 16 species & 7.1 & 5 & 0.84 & 0.50 & 0.60 \\
\hline 60 species & 12.5 & 7 & 0.93 & 0.33 & 0.70 \\
\hline
\end{tabular}

\section{Results}

Our plant-pollinator webs comprised 5729 individual flower visitors from 34 pollinator species, connected by 315 links. Thirty flowering plant species were involved in the plantpollinator interaction webs. We did all analyses with original species data, as the mean 
species saturation per plant-richness level was high $(84.62 \pm 10.7 \%$ of ACE estimated richness, $\mathrm{n}=73$ ).

Several general patterns arose from the quantitative plant-pollinator webs across the floral diversity gradent (Fig. 1). First, honeybees (Apis mellifera) are most abundant over the whole plant diversity gradient with 2824 visits (49.4\%), followed by bumblebees representing $29 \%$ of all flower visits. Solitary bees were less abundant, representing $4 \%$ of all flower visits. Second, the composition of the pollinator community on the guild level (proportion of a solitary bees, bumblebees and honeybees of all flower visits) did not change along the gradient of floral plant diversity (solitary bees: $F_{1,51}=0.02, p=0.896$; bumblebees: $F_{1,51}=0.15$; $\mathrm{p}=0.704$; honeybees: $\left.\mathrm{F}_{1,51}=1.59 ; \mathrm{p}=0.214\right)$.

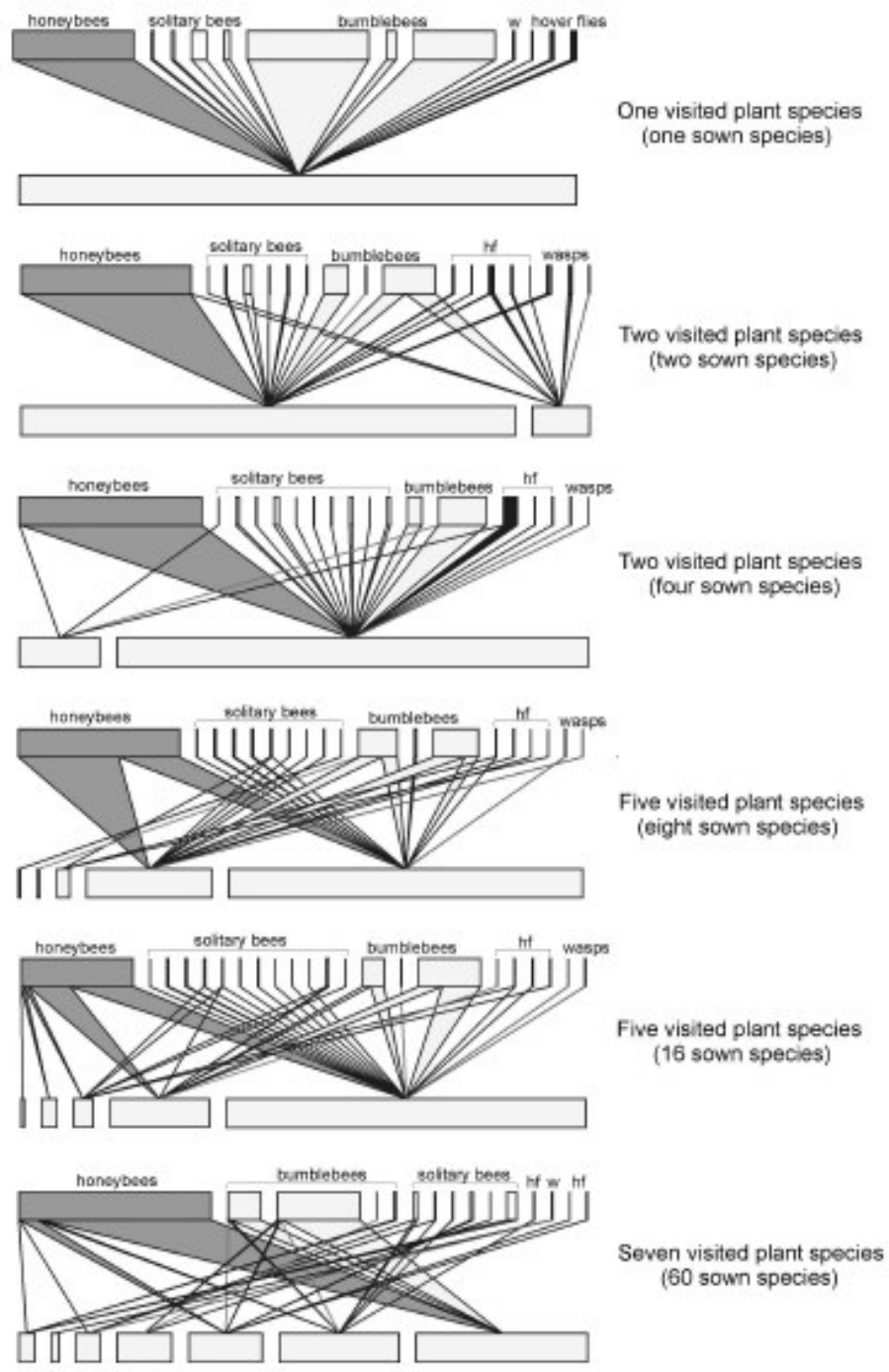

\section{Figure 1:}

Visualization of quantitative plant-pollinator networks in different plant-diversity levels (monocultures, 2-, 4-, 8-, 16 and 60 species mixtures). Each flowering species of plants and each pollinator species are represented by a rectangle. Further pollinator species are summarized in the five pollinator guilds honeybees, solitary bees, bumblebees, hover flies (hf) and wasps (w). The lower line represents flower abundance (percent blossom cover) and the upper line represents pollinator frequency. Widths of rectangles are proportional to their abundance or frequency in the field site, and the size of lines connecting them represents the recorded number of interactions. As a summary, the webs show interaction data pooled across all replicates for each plantdiversity level, although analyses were conducted on a per-site basis. Note that plant species diversity is not always the same as floral species diversity (see Table 1). All webs are scaled to make visual inspection and comparison possible. 


\section{Specialization at the network level}

Linkage density increased with increasing number of flowering plant species (Fig. 2A). In contrast, an increase in floral diversity led to a significant decrease in network connectance (Fig. 2B, Table 2). After including network size into the analyses, we still detected a significant impact of floral diversity on linkage density and connectance. The quantitative measure, the network specialization (degree of network organization), did not change with floral diversity (Fig. 2C) and had a mean value of 0.62 \pm SE $0.05(n=29)$.

A

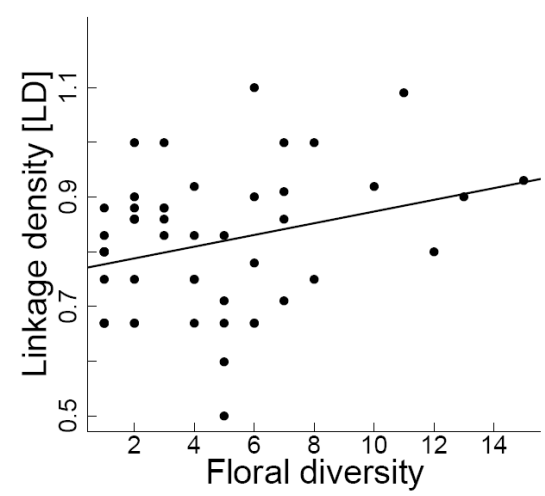

B

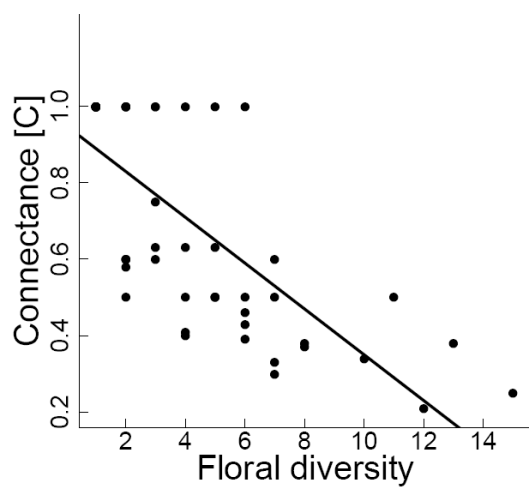

$\mathrm{C}$

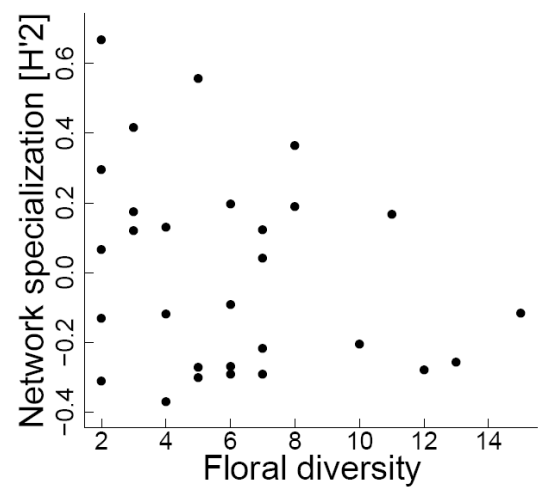

Figure 2:

The relationships between floral diversity and pollinator assemblages expressed as (a) linkage density [LD], (b) network connectance [C], and (c) network specialization [H'2]. The values of network specialization are the residuals of the data to control for the effect of the second variable, blossom cover, in the model.

Table 2:

Linear models for the effects of floral diversity on several food web metrics. For the analyses floral abundance and floral diversity entered the model in that order. For linkage density and connectance, additionally network size entered the model first and for specialization indices we included the number of involved pollinator guilds as additional response variable.

\begin{tabular}{lcc}
\hline Variable & $\mathbf{F}$ & $\mathbf{p}$ \\
\hline Linkage density & $\mathbf{F}_{1,51}=\mathbf{7 . 9 4}$ & $\mathbf{0 . 0 0 7 * *}$ \\
Connectance & $\mathbf{F}_{\mathbf{1 , 5 1}}=\mathbf{2 0 . 0 3}$ & $<\mathbf{0 . 0 0 1 * * *}$ \\
Network specialization & $\mathrm{F}_{1,28}=0.25$ & 0.618 \\
Pollinator specialization & $\mathrm{F}_{1,28}=1.50$ & 0.231 \\
Specialization of solitary bees & $\mathbf{F}_{1,23}=\mathbf{4 . 3 7}$ & $\mathbf{0 . 0 4 9 *}$ \\
Specialization of bumblebees & $\mathrm{F}_{1,25}=0.33$ & 0.570 \\
Specialization of honeybees & $\mathrm{F}_{1,26}=3.29$ & 0.082 \\
Plant specialization & $\mathrm{F}_{1,28}=0.44$ & 0.511 \\
\hline
\end{tabular}




\section{Specialization at the guild and species level}

The average number of pollinator species per plant species decreased with increasing floral diversity $\left(\mathrm{F}_{1,51}=11.30 ; \mathrm{p}=0.001 ; \mathrm{Fig} .3 \mathrm{~A}\right)$, yet we found no effects of floral diversity on the number of flower visits per plant species $\left(\mathrm{F}_{1,51}=2.16 ; \mathrm{p}=0.147\right.$; Fig. 3B $)$. Further, the overall plant specialization $\left[<\mathrm{d}^{\prime}\right.$ plant $\left.\rangle\right]$ showed no changes with increasing floral diversity (Table 2 ).

The specialization analyses did not show changes in overall specialization of pollinators $[<\mathrm{d}$ ' poll $>]$ to floral diversity (Table 2 ). This may be caused by the lack of bumble bee specialization to floral resoures. Contrastingly, honeybees tended to increase their resource specialization with increasing floral diversity (Fig. 3C; Table 2), and this pattern was even stronger for solitary bees (Fig. 3D; Table 2). Importantly, the marginally significant specialization patterns for honeybees and the significant patterns for solitary bees remained after including the number of involved pollinator guilds as a co-variable into the analyses. The mean values of the specialization indices ranged from $d^{\prime}=0.26$ for honeybees, $d^{\prime}=0.27$ for bumblebees, up to d' $=0.38$ for solitary bees.

A

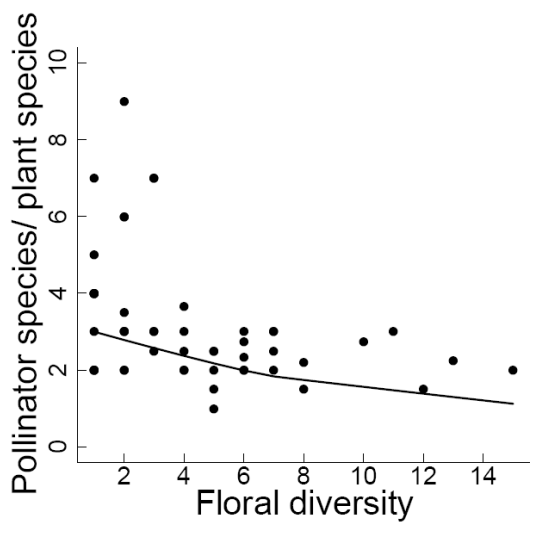

C

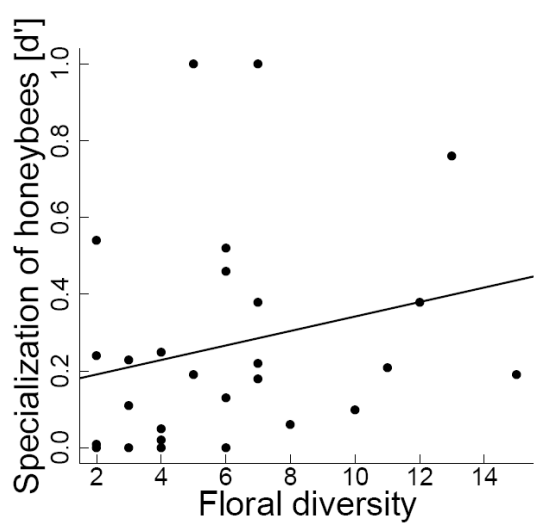

B

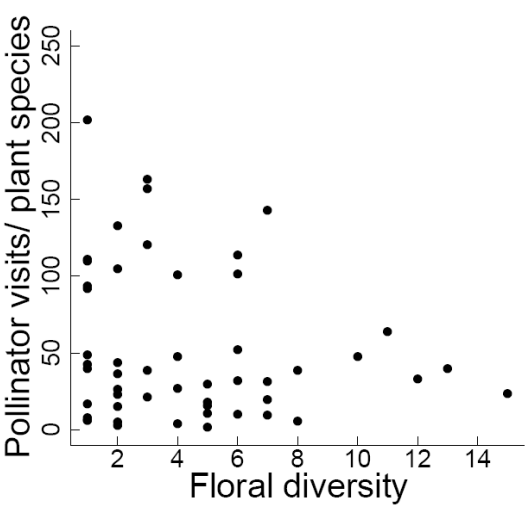

D

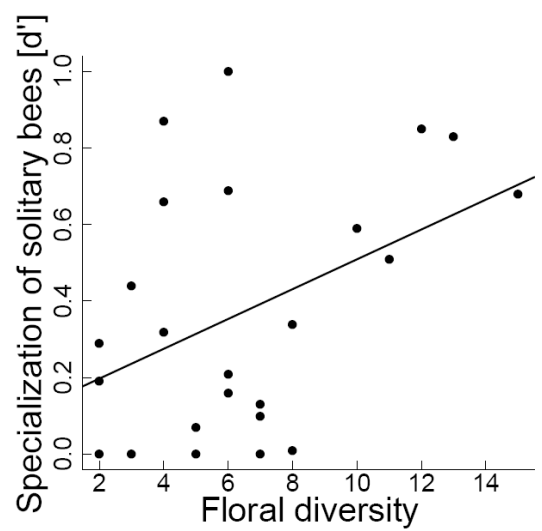

Figure 3:

The effects of floral diversity on (a) the average number of pollinator species observed visiting each plant species, (b) the number of flower visits per plant species, (c) resource specialization of honeybees [d' $\left.{ }_{\text {Apis }}\right]$, and (d) specialization of solitary bees [d' $\left.\mathrm{d}_{\text {bees }}\right]$. 


\section{Discussion}

Network level

Analyses of classical qualitative food web metrics showed an increase in linkage density with increasing floral diversity. Increases in linkage density led to higher network complexity as shown in former studies (May 1972) and is caused by the higher attractiveness of more diverse floral displays. Increased complexity is hypothesized to lead to higher ecosystem stability of the plant-pollinator network against disturbances such as species extinctions (MacArthur 1955, Elton 1958, Naem and Li 1997, Naem 1998). The quantitative interaction webs also support of the idea of enhanced ecosystem stability, because the proportion of weak links increases with increasing floral diversity (Fig. 1), and hence the probability that a weak link goes extinct and not a strong one also increases with floral diversity. In diverse plantpollinator communities link extinction is most likely the extinction of a weak link, and according to the concept of the insurance hypothesis, this may have a small impact on network functioning, because one bee species may occupy the functional niche of an extinct species and therefore compensate for the loss in pollination service (Naem and Li 1997, Yachi and Loreau 1999). Contrastingly, in low diversity plots the link extinction may lead to stronger disturbances and loss in overall pollination success (Memmott et al. 2004, Jordano et al. 2003), because the extinct link is most likely a strong link.

The increase in network complexity that accompanies increasing floral diversity was associated with a decrease in qualitative network connectance. This pattern of decreasing connectance supports published studies (Jordano 1987, Basilio et al. 2006). It may indicates an increase in pollinator specialization at high diverse plots (Jordano 1987), because the pollinators have a greater food choice (more flowering plant species), but feed only on a small proportion of the available resources.

In contrast to the results of the classical qualitative web metrics, there were no changes in the quantitative analyses of network specialization $\left[\mathrm{H}_{2}{ }_{2}\right]$. Our finding of a declining network connectance implies an increase of pollinator specialization, but the deviation from a random link distribution was equal at all diversity levels, indicating a similar degree of organization (specialization) along the plant diversity gradient. Understanding these contrasting results requires more detailed analyses at the guild and species levels.

\section{Guild and species level}

The average number of pollinators per plant species decreased with increasing floral diversity, but the frequency of pollinator visits per plant species was not influenced by the floral 
diversity. These patterns may indicate a higher resource specialization of the pollinator species, because the pollinators chose lower numbers of plant species for their feeding visits, even if the frequency of their visits per plant species did not change. Our hypothesized consequence was that the lower species number and increased resource specialization may mean higher flower constancy and thereby, higher pollination effectiveness (Sih et al. 1998). This hypothesis was supported by our findings from the quantitative specialization indices, which showed a higher specificity of solitary bees and, with marginal significance, of honeybees at higher floral diversity.

The missing influence of floral diversity on the overall specialization of pollinators is due to a missing specialization in bumblebees (Table 2), which are known to be generalist feeders, with few changes in resource specialization (Eickwort and Ginsberg 1980, Naem and Li 1997, von Hagen 1990).

For the solitary bee species we expected the increased specialization at higher floral diversity, because solitary bees contain a larger number of relatively specialized species, selecting few flowering species and often relatively rare floral resources (Eickwort and Ginsberg 1980, Westrich 1990). Surprisingly the level of mean solitary bee specialization was relatively low $(\mathrm{d}=0.38)$, which may be due to the fact that the observed solitary bee species are known to be basically polylectic and relatively unspecialized (Westrich 1990). This in turn means that the increasing resource specialization of solitary bees we found arised by a change in feeding behavior of the pollinators and not by changes in species composition (an increase of specialized bee species). Changing behavior also explains the surprising feeding specialization of honeybees, because honeybees are known for a broad food plant use (Steffan-Dewenter et al. 2002). In both pollinator guilds, honeybees and solitary bees, the same mechanisms appeared to apply in that a diverse floral display offers the possibility to choose the most attractive plant resource, leading to a higher specialization and thereby, higher pollination success through flower constancy. More specialized species are predicted to be more efficient consumers than generalists (Rana et al. 2002). For our study these examples from food web theory suggest that higher specialization of solitary and honeybees leads to higher flower constancy and to better pollination success (Eickwort and Ginsberg 1980). Larsson (2005) found increased pollen removal by specialized pollinators of the herb Knautia arvensis (Dipsacaceae) in comparison to generalists. The increased pollen removal may indicate that they transfer high amounts of pollen to their own larvae or to the stigmas of conspecific plants, leading to higher effectiveness in pollination. 
In our study, solitary bees represent only $4 \%$ of all flower visitors, but current studies show that a diverse community of solitary bees can provide sufficient pollination in the absence of social species (Winfree et al. 2007). In highly diverse flowering plots, where solitary bee diversity and specialization become enhanced, solitary bees may be able to take over pollination work of honeybees; an insurance effect that becomes important with currently decreasing honeybee colonies. Contrastingly, low diversity flowering plots with their low bee diversity and specialization should be a less effective buffer against pollination losses in case of honeybee declines (Kremen et al. 2004).

In conclusion, the highly replicated, experimental plant-diversity gradient of the Jena experiment allowed us to show strong changes of structure and resource specialization in the pollinator communities with changing flower diversity, excluding potential confounding effects such as fertilization and changes in community structure. We found higher linkage density in more diverse floral displays, which may result in enhanced network stability (Gardner and Ashby 1970, McCann 2000). Further, the enhanced specialization of solitary and honeybee pollinators should result in improved pollination success. Because of the drastic current honeybee losses, the more specialized solitary bees in diverse habitats might be a most important buffer sustaining long-term pollination in a changing environment. The high bee diversity, specialization, and linkage density in highly diverse grasslands, point to the necessity to conserve diverse floral displays in a changing world.

\section{Acknowledgements}

We thank all people helping with the management of the Jena-Experiment, especially Alexandra Weigelt as field coordinator and the gardeners Steffen Eismann, Silke Hengelhaupt, Sylvia Junghans, Ute Köber, Katja Kunze, Gerlinde Kratzsch, Heike Scheffler, and Ulrike Wehmeier. The help during fieldwork by Sylvia Creutzburg, Michaela Knauer and Heike Baldeweg and all the helpers during the weeding campaigns is greatly acknowledged.

We also thank Roland Schmid for programming the web display and Nico and Nils Blüthgen for helpful comments on the analyses. The Jena Experiment is funded by the Deutsche Forschungsgemeinschaft, with additional support from the Friedrich Schiller University of Jena and the Max Planck Society. 


\section{References}

Basilio, A.M., Medan, D., Torretta, J.P. and Bartoloni, N.J. 2006. A year-long plant-pollinator network. - Austral Ecology 31: 975-983.

Blüthgen, N., Blüthgen, N. and Menzel, F. 2006. Measuring specialization in species interaction networks. - BMC Ecology 6: 9.

Blüthgen, N., Menzel, F., Hovestadt, T., Fiala, B. and Blüthgen, N. 2007. Specialization, constraints, and conflicting interests in mutualistic networks. - Current Biology 17: 341346.

Burd, M. 1994. Bateman principle and plant reproduction - the role of pollen limitation in fruit and seed set. - Botanical Review 60: 83-139.

Cartar, R.V. 2004. Resource tracking by bumble bees: Responses to plant-level differences in quality. - Ecology 85: 2764-2771.

Committee on the Status of Pollinators in North America; National Research Council 2007.

Eickwort, G.C. and Ginsberg, H.S. 1980. Foraging and mating-behaviour in Apoidea. Annual Review of Entomology 25: 421-446.

Elton, C.S. 1958. Ecology of invasions by animals and plants. Chapman \& Hall, London.

Fontaine, C., Dajoz, I., Meriguet, J. and Loreau, M. 2006. Functional diversity of plantpollinator interaction webs enhances the persistance of plant communities. - PLoS Biol 4.

Forup, M.L. and Memmott, J. 2005. The restoration of plant-pollinator interactions in hay meadows. - Restoration Ecology 13: 265-274.

Gardner, M.R. and Ashby, W.R. 1970. Connectance of Large Dynamic (Cybernetic) Systems - Critical Values for Stability. - Nature 228: 784.

Ghazoul, J. 2006. Floral diversity and the facilitation of pollination. - Journal of Ecology 94: 295-304.

Ives, A.R. and Cardinale, B.J. 2004. Food-web interactions govern the resistance of communities after non-random extinctions. - Nature 429: 174-177.

Jordano, P. 1987. Patterns of Mutualistic Interactions in Pollination and Seed Dispersal Connectance, Dependence Asymmetries, and Coevolution. - American Naturalist 129: 657-677.

Jordano, P., Bascompte, J. and Olesen, J.M. 2003. Invariant properties in coevolutionary networks of plant-animal interactions. - Ecology Letters 6: 69-81.

Klein, A.M., Vaissiere, B.E., Cane, J.H., Steffan-Dewenter, I., Cunningham, S.A., Kremen, C. and Tscharntke, T. 2007. Importance of pollinators in changing landscapes for world crops. - Proceedings of the Royal Society B-Biological Sciences 274: 303-313. 
Kremen. C., Williams. N.M., Bugg. R.L., Fay. J.P. and Thorp. R.W. 2004. The area requirements of an ecosystem service: crop pollination by native bee communities in California. - Ecology Letters 7: 1109-1119.

Larsson, M. 2005. Higher pollinator effectiveness by specialist than generalist flower-visitors of unspecialized Knauita arvensis (Dipsacaceae). - Oecologia 146: 394-403.

MacArthur, R.H. 1955. Fluctuations of animal populations and a measure of community stability. - Ecology 36: 533-536.

May, R.M. 1972. Will a Large Complex System Be Stable. - Nature 238: 413.

McCann, K.S. 2000. The diversity-stability debate. - Nature 405: 228-233.

Melian, C.J. and Bascompte, J. 2002. Food web structure and habitat loss. - Ecology Letters 5: 37-46.

Memmott, J. 1999. The structure of a plant-pollinator food web. - Ecology Letters 2: 276-280.

Memmott J., Waser N.M. and Price M.V. 2004. Tolerance of pollination networks to species extinctions. - Proceedings of the Royal Society of London Series B-Biological Sciences 271: 2605-2611.

Michener, C. 2000. The Bees of the World. Johns Hopkins University Press, Baltimore and London.

Montoya, J.M., Pimm, S.L. and Sole, R.V. 2006. Ecological networks and their fragility. Nature 442: 259-264.

Naeem, S. and Li, S.B. 1997. Biodiversity enhances ecosystem reliability. - Nature 390: 507509.

Naeem, S. 1998. Species redundancy and ecosystem reliability. - Conserv. Biol. 12: 39-45.

Ollerton, J. and Cranmer, L. 2002. Latitudinal trends in plant-pollinator interactions: are tropical plants more specialised? - Oikos 98: 340-350.

Rana, J.S., Dixon, A.F.G. and Jarosik, V. 2002. Costs and benefits of prey specialization in a generalist insect predator. - Journal of Animal Ecology 71: 15-22.

Roscher, C., Schumacher, J., Baade, J., Wilcke, W., Gleixner, G., Weisser, W.W., Schmid, B. and Schulze, E.D. 2004. The role of biodiversity for element cycling and trophic interactions: an experimental approach in a grassland community. - Basic and Applied Ecology 5: 107-121.

Sih, A., Englund G. and Wooster D. 1998. Emergent impacts of multiple predators on prey. Trends in Ecology \& Evolution 13: 350-355. 
Spaethe, J., Tautz, J. and Chittka, L. 2001. Visual constraints in foraging bumblebees: Flower size and color affect search time and flight behavior. - Proceedings of the National Academy of Sciences of the United States of America 98: 3898-3903.

Steffan-Dewenter, I., Münzenberg, U., Bürger, C., Thies, C. and Tscharntke, T. 2002. Scaledependent effects of lanscape context on three pollinator guilds. - Ecology 83: 1421-1432.

Stokstad, E. 2007. The case of the empty hives. - Science 316: 970-972.

Thompson, J.D. 2001. How do visitation patterns vary among pollinators in relation to floral display and floral design in a generalist pollination system? - Oecologia 126: 386-394.

Totland, O. and Matthews, I. 1998. Determinants of pollinator activity and flower preference in the early spring blooming Crocus vernus. - Acta Oecologica-International Journal of Ecology 19: 155-165.

Vazquez, D.P. and Aizen, M.A. 2003. Null model analyses of specialization in plantpollinator interactions. - Ecology 84: 2493-2501.

von Hagen, E. 1990. Bumble bees- identifying, settling, proliferating, protecting. Naturbuchverlag, Augsburg, german.

Westrich, P. 1990. The wild bees Baden-Württembergs Special section: Genera and species. Ulmer Verlag, Stuttgart, german.

Winfree, R., Williams, N.M., Dushoff, J. and Kremen, C. 2007. Native bees provide insurance against ongoing honey bee losses. - Ecology Letters 10: 1105-1113.

Yachi, S. and Loreau M. 1999. Biodiversity and ecosystem productivity in a fluctuating environment: The insurance hypothesis. - Proceedings of the National Academy of Sciences of the United States of America 96: 1463-1468. 


\section{CHAPTER 5}

EXPERIMENTAL SMALL-SCALE CHANGES IN PLANT DIVERSITY AFFECT NESTING BEES; WASPS AND THEIR NATURAL ENEMIES

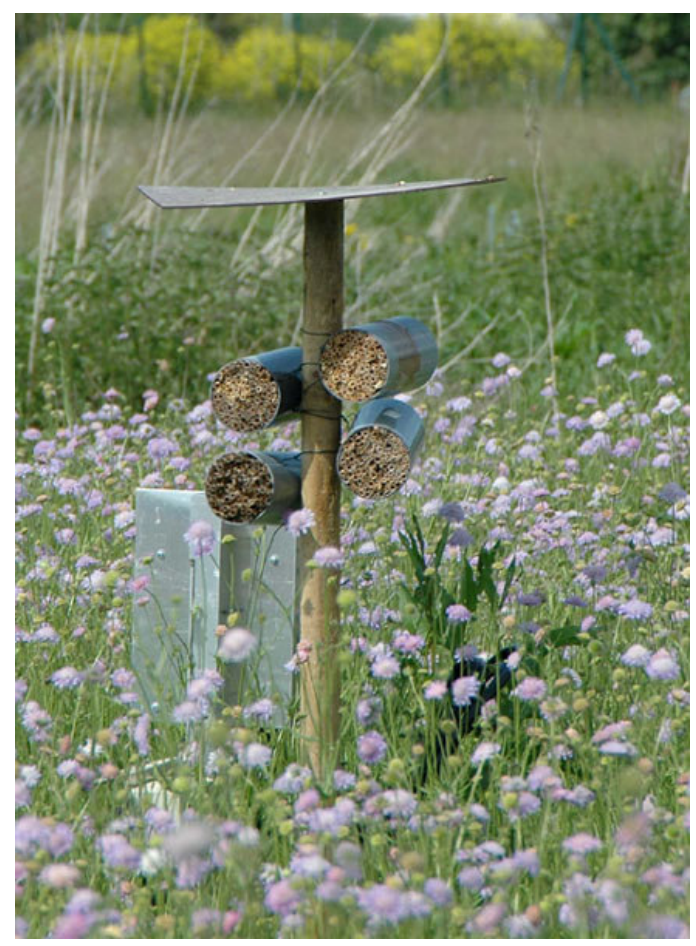




\begin{abstract}
Bees as pollinators for many wild and crop plants and wasps as predators (pest control) are important functional guilds of terrestrial ecosystems and they are often related to changes in plant species richness. We studied an experimental plant diversity gradient in order to understand the interactions between plants and these mobile insects, as in non-experimental field surveys plant richness is often confounded with gradients in management, soil fertility and community composition. We observed species richness and abundance of cavity-nesting bees, wasps and their parasitoids in 82 plots of different grassland communities over two years, using standardized nesting resources.

High numbers of flowering plant species led to higher abundances of pollinators (bees) and predators (wasps), whereas higher abundances bees and wasps as well increased their species richness. These more diverse host communities we found with increasing number of flowering plant species attracted a higher number of parasitoid species, which increased their function (parasitism). However, increasing host diversity could also limit parasitism; hence cavity-nest communities in species rich plant communities might be more resistant to consumption. In conclusion, grasslands with high numbers of plant species enhance the diversity and abundance of cavity-nesting bees and wasps and their associated ecosystem services (e.g. pollination, pest control), underlining the need to conserve diverse grasslands.
\end{abstract}

\title{
Introduction
}

During the past decades a worldwide loss of biodiversity has been identified (Robinson and Sutherland 2002, Foley et al. 2005, Biesmeijer et al. 2006), and understanding the consequences of species loss for biotic interactions, and associated ecosystem services is important and has become a major focus in ecological studies (Montoya et al. 2003, Kremen 2005, Tscharntke et al. 2005, Balvanera et al. 2006, Tylianakis et al. 2007).

Enhanced plant species richness has been hypothesized to promote richness of mobile organisms (e.g. Ebeling et al. submitted) and positive effects of plant species richness on insect diversity or abundance has often been shown (e.g. Klein et al. 2002, Perfecto et al. 2003, Potts 2006, Albrecht et al. 2007). But differences in plant species richness among sites and habitat types in these studies are mostly the result of differences in habitat variables such as land-use intensity, making it difficult to attribute changes of insect communities directly to differences in plant diversity. Intensive land management often reduces plant species richness, but also entails changes in nutrient and water contents, thereby leading to changes in plant fitness parameter as plant biomass, vegetation height or flower size (Drenovsky and Richards 
2005). Insect communities in turn respond to these changes, making it difficult to study plant species richness per se (Spaethe et al. 2001, Thompson 2001, Cartar 2004). Several studies analyzed landscape effects of mobile organisms such as flying bees and wasps and showed strong negative effects e.g. of fragmentation, landscape complexity, or land-use intensification on insect diversity and its provided ecosystem services (e.g. pollination, pest control, parasitism) (e.g. Steffan-Dewenter 2002, Albrecht et al. 2007, Ricketts et al. 2008, Holzschuh et al. submitted). However, the interesting point, if highly mobile organisms are affected also by small-scale changes has rarely been studied.

We studied the effect of plant species richness per se in experimental grasslands by using mobile cavity-nesting bees and wasps and analyze their trophic interactions with the diversity of natural enemies (parasitoids and cleptoparasites, hereafter: parasitoids) and their functioning, measured as parasitism rates. Cavity-nesting hymenoptera are an eligible system to study such complex systems, due to their defined size, high species richness and trophic complexity, and because of the importance of bees and wasps for ecosystem services (Tscharntke et al. 1998, Klein et al. 2007, Tylianakis et al. 2007). Bees as pollinators for many wild and crop plants (Klein et al. 2007) and wasps as predators and parasitoids (pest control) are important functional guilds of terrestrial ecosystems (LaSalle and Gauld 1993) and studying their dependence on changing plant species richness is of great interest. Plant diversity is predicted to influence diversity and density of cavity-nesting bees and wasps (Tscharntke et al. 1998, Klein et al. 2002, Albrecht et al. 2007, Tylianakis et al. 2007). These changes in the host community (bees and wasps) can also mediate changes in the resistance to consumption by their parasitoid community (Tylianakis et al. 2006a, Veddeler unpublished data).

We analyzed cavity-nesting communities on the experimental site of the "Jena experiment", comprising 78 grassland plots (20x20m) of manipulated plant species richness $(1,2,4,8,16$ species). The $400 \mathrm{~m}^{2}$ plots were sown in a way that plant species composition was randomised, and not confounded by plant community structure (e.g. species identity). We examined:

(1) the relation between plant species richness to species richness and reproduction (abundance) of cavity-nesting hymenoptera;

(2) how changes in the host community affect the diversity of parasitoids, and

(3) if plant species richness affects the resistance of hosts against consumption (parasitism). 


\section{Material and Methods}

Study site

This study was carried out using the experimental plant-diversity design of the Jena

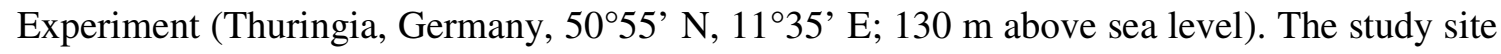
of the "The Jena Experiment" was established in May 2002 and is located at the floodplain of the river Saale. Before the sowing of the experimental species started, arable farming practices were carried out over several years. The plant communities were seeded in 78 large plots of $20 \times 20 \mathrm{~m}$ with a gradient of species richness (1, 2, 4, 8 and 16) per plot. For any combination of plant species richness level, the particular species mixtures were randomly selected from a species pool of 60 common grassland species (Roscher et al. 2004). Monocultures, 2-species mixtures, 4-species mixtures and 8-species mixtures are represented with 16 replicates each and 16-species mixtures with 14 replicates. Diversity treatments were assigned randomly to plots within four blocks, taking abiotic gradients (distance to the river Saale) into account. All plots are mowed twice per year, a management regime used in meadows designed for intensive hay production. For our observation of cavity-nesting hymenoptera we installed a wooden post with four nesting traps on each post in the center of each plot. As additional biotic parameter the number of flowering species where counted monthly (each year from Mai- August) to get the number of plant species flowering during the nest-building period.

\section{Trap nests}

Each of the 78 plots consists of a wooden post of $1.5 \mathrm{~m}$ height, each with four nesting traps and was set up from end of April to September in 2005 and 2006. All trap nests consisted of a plastic tube of $11 \mathrm{~cm}$ diameter, containing around 150 internodes of the common reed Phragmites australis (Cav.) Trin.. The Internodes were cut to a length of $20 \mathrm{~cm}$ and had an equal mix of different diameters ranging from 2 to $10 \mathrm{~mm}$ (Tscharntke et al. 1998). The trap nests were protected against rain by wooden roofs $(50 \times 50 \mathrm{~cm})$.

In both study years, all nesting traps were sampled in the middle of September and stored at $4^{\circ} \mathrm{C}$ for 12 weeks to mimic a hibernation phase before all reed internodes with nests of bees or wasps were taken out and opened with a scalpel in the laboratory. The opened nests allowed a preliminary identification of the insect genus (Gathmann and Tscharntke 1999) and were reared separately in glass tubes for imagines to emerge for final determination. For each nest, the number of intact and parasitized brood cells, the number and identity of host species and their natural enemies were counted. Species richness was measured as the number of observed 
species, and abundance of the cavity- nesting species as the number of brood cells per plot. Abundance of natural enemies was the number of parasitized brood cells, and parasitism rate was the ratio between the numbers of parasitized brood cells to the number of all brood cells build by the bee or wasp species.

\section{Species identification}

Megachilidae were identified based on the work of Scheuchl and Colletidae with help of the work of Amiet (1999). Eumenid and specid wasps were identified based on the work of Schmid-Egger (2003) and Dollfuss (1991). Chrysididae were identified based on the work of Kunz (1994) and Linsenmaier (1997). Other parasitoid species were identified to family level based on Bährmann (1995).

\section{Statistical analysis}

Data analyzing was performed using the statistical software R (R Development Core Team, Vienna Austria. http://www.R-project.org.). Data were square-root or log transformed if Q-Q plots showed deviations from normality (see Table 1-4).

We analyzed the effect of vegetation terms on the cavity-nesting community using a mixed effects model with type-I sums of squares (Crawley 2002; Schmid et al. 2002). A model was fitted with the following sequence: block (factor), type of adjacent habitat (edge type; factor), floral diversity (number of flowering plant species; numeric) and plant species richness (numeric). The factor block, reaching from one to four, represents a gradient in abiotic conditions, induced by the distance to the river Saale. Plots containing to block one are closest to the river, whereas block four has the largest distance to the river. We classified four types of edged: $0=$ no connection to field margins, $1=$ connection to river, $2=$ connection to meadow or $3=$ connection to urban structure (street and houses).

Additional terms like abundance data for correction of sample size were added to some models (see below) and always entered the model first. For the analyses of species richness data (species richness of wasps and bees, species richness of natural enemies) we added abundance data (number of brood cells of bees and wasps or abundance of natural enemies) to the model. Models analyzing the effect on species richness of parasitoids were supplemented by species richness of their hosts. Models having parasitism rates as independent term were supplemented by species richness data of hosts and parasitoids. 


\section{Results}

Cavity-nesting community structure

Overall, 1921 nests and 7044 brood cells of 41 hymenoptera host bee and wasp species were found: twenty-two species of bees (Apidae) and nineteen species of wasps. Digger wasps were represented with ten species (Sphecidae), mason wasps (Eumenidae) with eight species, and spider wasps (Pompilidae) with one species. Digger wasps were the most abundant family with a share of $61.1 \%$ of all brood cells, followed by bees (35\%), mason wasps $(3.5 \%)$ and spider wasps $(0.4 \%)$. Twelve species of natural enemies attacked an average of $10 \%$ of brood cells of bees, $12.7 \%$ of brood cells of digger wasps, $16.23 \%$ of brood cells of mason wasps, and $8.5 \%$ of brood cells of spider wasps.

A

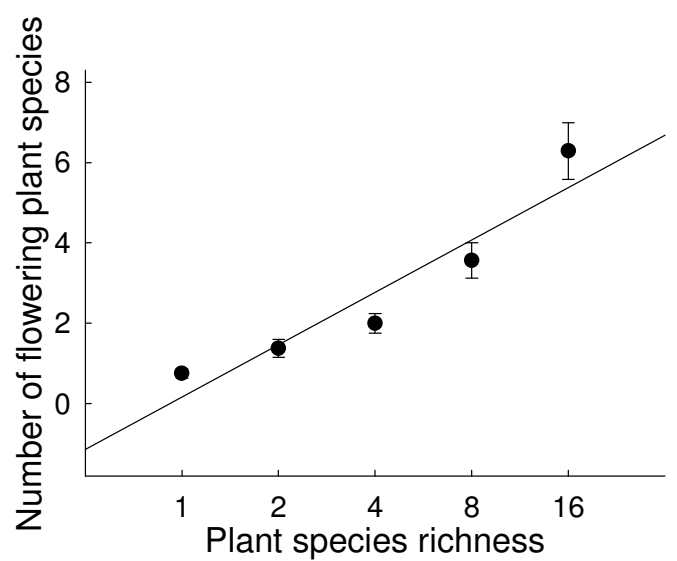

B

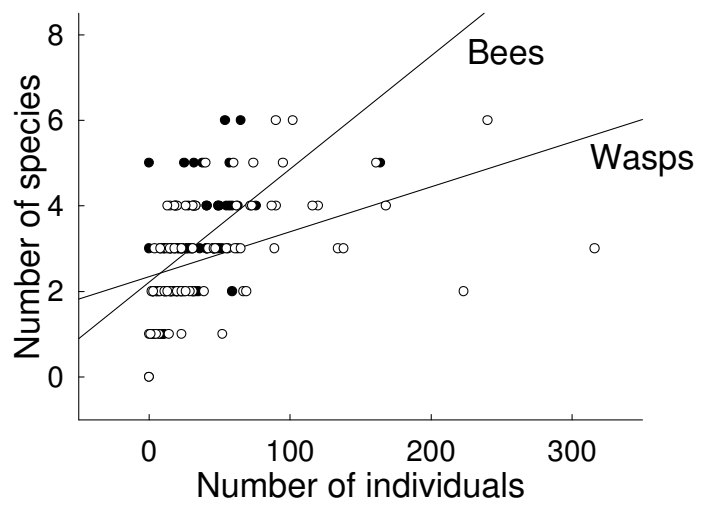

Figure 1:

Effects of A) plant species richness on the number of flowering plant species, and B) the number of individuals on the number of host species. Black circles indicate the relation for bees and white circles for wasps. Lines show mean squares fits for the presented variables and black circles show mean values \pm Standard error.

Table 1:

Columns 3-6 show F- and P-values, for the response variables listed in the first row (without correction for sample size by adding abundance data into the model). The first column shows the main factors tested in the models, in the sequence in which they were fitted. Bold font indicates significances. Minus sign indicates negative correlation, plus a positive one. Models always started with a degree of freedom of 77, resulting from 78 plots. The second row shows the degrees of freedom (df) for each of the predictor variables.

${ }^{*} \log$ transformed, ${ }^{\dagger}$ square-root transformed in cause of non-normal distribution

\begin{tabular}{lccccc}
\hline & \multicolumn{2}{c}{ Number of bee species } & \multicolumn{2}{c}{ Number of wasp species ${ }^{\dagger}$} \\
Explainatory variable & d.f. & F-value & P-value & F-value & P-value \\
\hline Block & 3 & 0.59 & 0.621 & $\mathbf{3 . 9 8}$ & $\mathbf{0 . 0 1 1}$ \\
Type of margin (river, meadow, street) & 3 & 0.68 & 0.563 & $\mathbf{9 . 4 6}$ & $<\mathbf{0 . 0 0 1}$ \\
Floral diversity & 1 & 2.35 & 0.130 & $\mathbf{1 0 . 4 2}$ & $\mathbf{0 . 0 0 1}(+)$ \\
* Plant species richness & 1 & 0.59 & 0.443 & 0.04 & 0.837 \\
\hline
\end{tabular}




\section{Effects of vegetation diversity on cavity-nesting bees and wasps}

An increase in plant species richness led to an increase in the number of flowering plant species (lm: $F_{1,76}=99.75, p<0.001 ;$ Figure 1A).

Species richness of bees was neither affected by plant species richness nor floral diversity (the number of plants in bloom) (Table 1), and only increased with increasing number of bee brood cells (Figure 1B). The brood cell abundance of bees in turn was significantly positively related to the floral diversity (Table 2, Figure 2A).

Species richness of wasps increased with increasing floral diversity (Table 1). Additionally species richness of wasps was higher in plots, which were directly connected to the river or a meadow (averaged four species/ plot) than in plots located at the street (averaged three species/ plot) or inside the experimental field site (averaged two species/ plot; Table 1). Accordingly we found a decrease in species richness of wasps with increasing distance to the river given by the randomized block design. After correction for sample size by including the number of brood cells of wasps into the analyses, high species richness of wasps was mainly driven by high brood cell abundance (Table 2, Figure 1B). The brood cell abundance of wasps was significantly positively related to the floral diversity (Table 2, Figure 2B) and was highest in plots directly connected to the river (averaged 140 brood cells/ plot) and the lowest in plots inside the experimental field site or located at the street (averaged 25 brood cells/ plot). Further wasp abundance decreased with increasing distance to the river (block effect) (Table 2).

\section{Table 2:}

Columns 3-10 show F- and P-values, for the response variables listed in the first row (with correction for sample size). The first column show the main factors tested in the models, in the sequence in which they were fitted. Other conventions follow Table 1.

\begin{tabular}{|c|c|c|c|c|c|c|c|c|c|}
\hline \multirow[b]{2}{*}{ Explainatory variable } & \multirow[b]{2}{*}{ d.f. } & \multicolumn{2}{|c|}{$\begin{array}{l}\text { Number of } \\
\text { bee species }\end{array}$} & \multicolumn{2}{|c|}{$\begin{array}{l}\text { Number of bee } \\
\text { individuals }\end{array}$} & \multicolumn{2}{|c|}{$\begin{array}{c}\text { Number of } \\
\text { wasp species }\end{array}$} & \multicolumn{2}{|c|}{$\begin{array}{l}\text { Number of wasp } \\
\text { individuals }\end{array}$} \\
\hline & & $\mathrm{F}$ & $\mathrm{P}$ & $\mathrm{F}$ & $\mathrm{P}$ & $\mathrm{F}$ & $\mathrm{P}$ & $\mathrm{F}$ & $\mathrm{P}$ \\
\hline Parasitized brood cells host & 1 & - & - & - & - & - & - & - & - \\
\hline Species richness parasites host & 1 & - & - & - & - & - & - & - & - \\
\hline Brood cells host & 1 & $\mathbf{5 4 . 4 0}$ & $<0.001(+)$ & - & - & 53.49 & $<0.001(+)$ & - & - \\
\hline Species richness host & 1 & - & - & - & - & - & - & - & - \\
\hline Block & 3 & 0.92 & 0.434 & 0.90 & 0.443 & 0.38 & 0.769 & 18.71 & $<0.001$ \\
\hline Type of margin & 3 & 0.53 & 0.662 & 1.16 & 0.331 & 2.02 & 0.119 & 12.69 & $<0.001$ \\
\hline Floral diversity & 1 & 0.01 & 0.906 & 7.59 & $0.007(+)$ & 3.65 & 0.060 & 14.05 & $<0.001(+)$ \\
\hline${ }^{*}$ Plant species richness & 1 & 0.01 & 0.932 & 1.13 & 0.291 & 0.01 & 0.918 & 0.11 & 0.745 \\
\hline
\end{tabular}


A

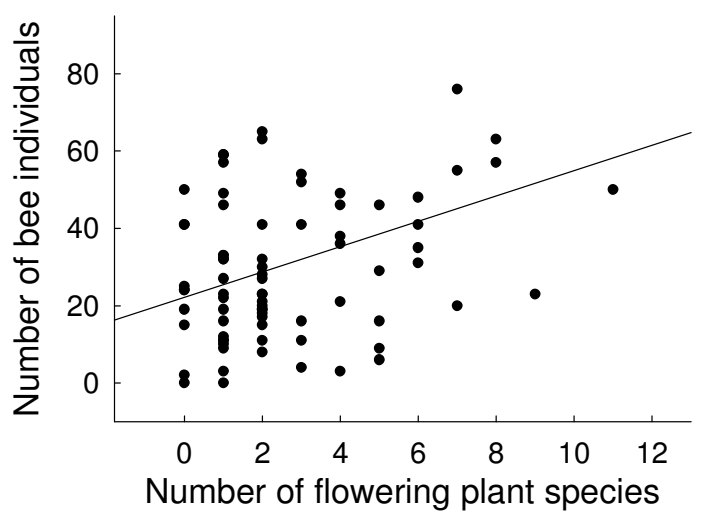

B

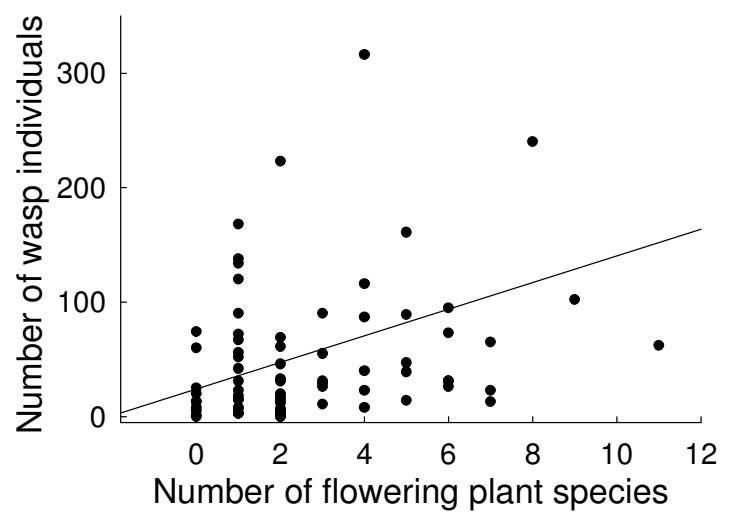

Figure 2:

Effects of the number of flowering plant species on A) the number of bee individuals, and B) the number of wasp individuals. Other conventions follow Figure 1.

Table 3:

Columns 3-6 show F- and P-values, for the response variables listed in the first row (without correction for sample size). The first column show the main factors tested in the models, in the sequence in which they were fitted. Other conventions follow Table 1.

\begin{tabular}{lccccc}
\hline & & \multicolumn{2}{c}{$\begin{array}{c}\text { Species richness } \\
\text { parasites bees }\end{array}$} & \multicolumn{2}{c}{ Species richness parasites } \\
Explainatory variable & d.f. & F-value & P-value & F-value & P-value \\
\hline Block & 3 & 0.37 & 0.78 & $\mathbf{1 0 . 2 9}$ & $<\mathbf{0 . 0 0 1}$ \\
Type of margin & 3 & 0.78 & 0.509 & $\mathbf{7 . 9 7}$ & $<\mathbf{0 . 0 0 1}$ \\
Floral diversity & 1 & 0.45 & 0.505 & $\mathbf{1 3 . 8 1}$ & $<\mathbf{0 . 0 0 1}(+)$ \\
${ }^{*}$ Plant species richness & 1 & 0.03 & 0.854 & 0.25 & 0.702 \\
\hline
\end{tabular}

Table 4: Columns 3-10 show F- and P-values, for the response variables listed in the first row (with correction for sample size). The first column show the main factors tested in the models, in the sequence in which they were fitted. Other conventions follow Table 1.

\begin{tabular}{|c|c|c|c|c|c|c|c|c|c|}
\hline \multirow[b]{2}{*}{ Explainatory variable } & \multirow[b]{2}{*}{ d.f. } & \multicolumn{2}{|c|}{$\begin{array}{l}\text { Species richness } \\
\text { parasitoids bees }\end{array}$} & \multicolumn{2}{|c|}{$\begin{array}{c}\text { Parasitism } \\
\text { bees } \%^{\dagger}\end{array}$} & \multicolumn{2}{|c|}{$\begin{array}{l}\text { Species richness } \\
\text { parasitoids wasps }\end{array}$} & \multicolumn{2}{|c|}{$\begin{array}{l}\text { Parasitism } \\
\text { wasps } \%^{\dagger}\end{array}$} \\
\hline & & $\mathrm{F}$ & $\mathrm{P}$ & $\mathrm{F}$ & $\mathrm{P}$ & $\mathrm{F}$ & $\mathrm{P}$ & $\mathrm{F}$ & $\mathrm{P}$ \\
\hline Parasitized brood cells & 1 & 83.26 & $<0.001(+)$ & - & - & 43.69 & $<0.001(+)$ & - & - \\
\hline Number of parasitoid species & 1 & - & - & 66.54 & $<0.001(+)$ & - & - & 16.07 & $<0.001(+)$ \\
\hline${ }^{\dagger}$ Individuals host & 1 & 6.19 & $0.015(+)$ & - & - & 46.56 & $<0.001(+)$ & - & - \\
\hline Number of species host & 1 & 5.04 & $0.028(+)$ & 12.18 & $<0.001(-)$ & 15.61 & $<0.001(+)$ & 8.83 & $0.004(-)$ \\
\hline Block & 3 & 0.39 & 0.755 & 0.28 & 0.839 & 5.05 & 0.003 & 0.79 & 0.499 \\
\hline Type of margin & 3 & 0.53 & 0.664 & 2.36 & 0.079 . & 0.97 & 0.408 & 0.40 & 0.752 \\
\hline Floral diversity & 1 & 0.06 & 0.815 & 0.87 & 0.354 & 2.55 & 0.115 & 4.87 & $0.031(+)$ \\
\hline * Plant species richness & 1 & 1.39 & 0.242 & 1.08 & 0.301 & 0.02 & 0.892 & 0.03 & 0.858 \\
\hline
\end{tabular}

\section{Effects of host richness and abundance on parasitoids and parasitism}

High parasitoid species richness, attacking bees, was mainly positively related to brood cell abundance of bees and their species richness (Table 4, Figure 3A). Further high numbers of parasitoid species of bees increased parasitism rate at cavity-nesting bees (Figure 4A), 
whereas species richness of bee hosts decreased parasitism rate (consumption by parasitoids) (Table 4).

A

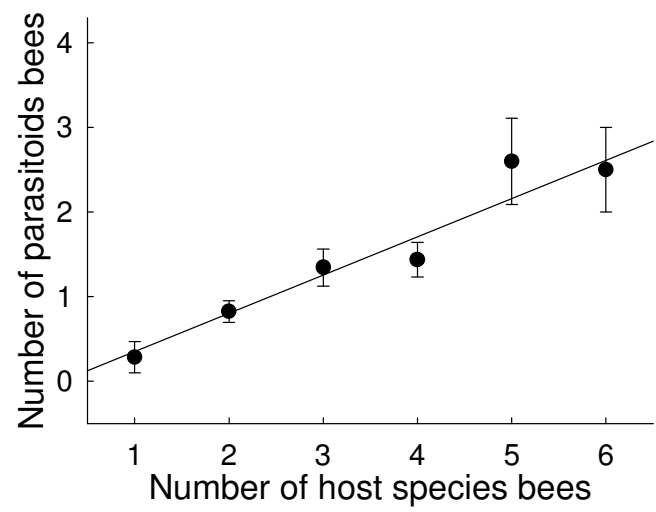

B

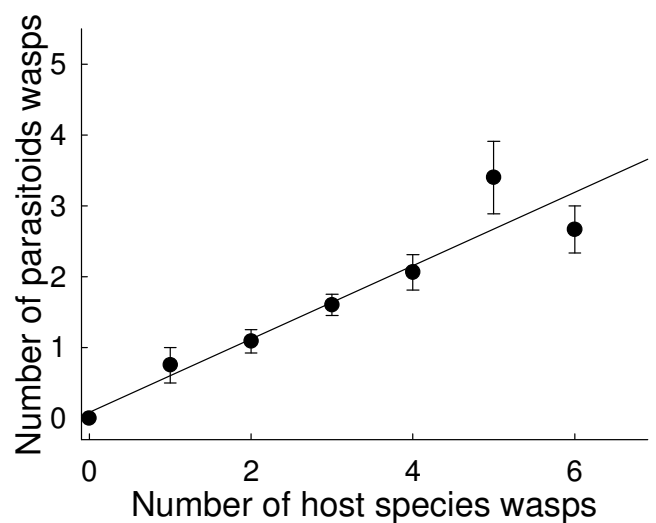

Figure 3:

Effects of A) the number of bee species on the number of parasitoids attacking bees, and B) the number of wasp species on parasitoids attacking wasps. Other conventions follow Figure 1.

Species richness of parasitoids, attacking wasps, increased with increasing floral diversity and was highest in plots directly connected to the river or meadow. Further, parasitoid diversity decreased with increasing distance to the river (Table 3). After correction for sample size by including abundance data in to the model, wasp parasitoid diversity increased with increasing number of wasp diversity and abundance (Table 4, Figure 3B), but the negative influence of increasing distance to the river still remained significant (Table 4). Parasitism of wasp species increased with increasing number of parasitoid species (Figure 4B), but decreased with increasing number of wasp species (Figure 5).

A

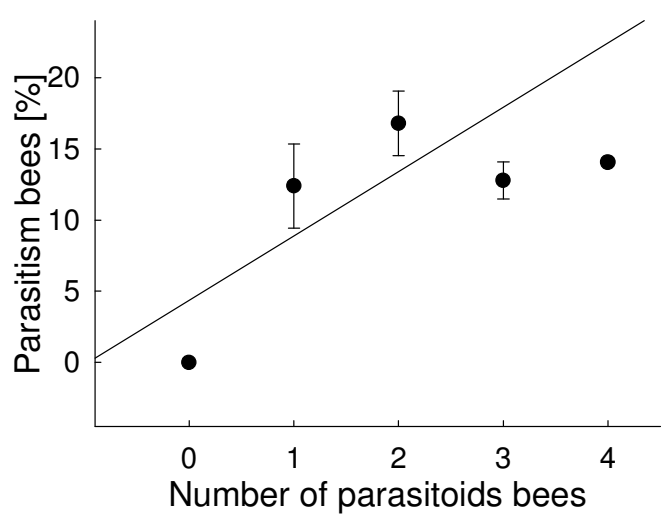

$\mathrm{B}$

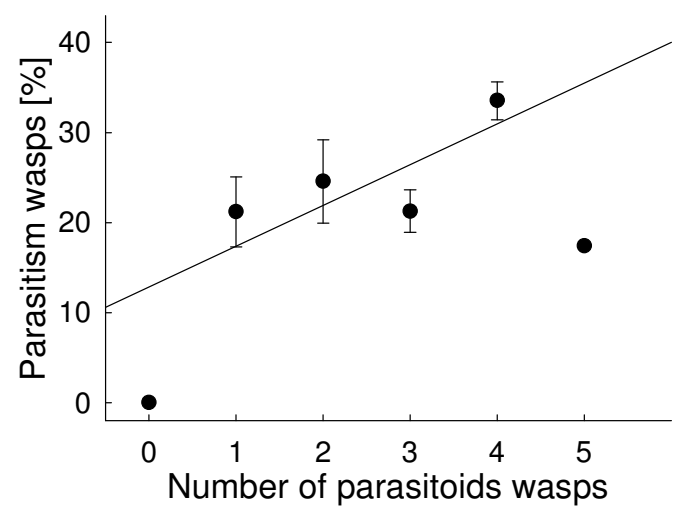

Figure 4:

Effects of A) the number of parasitoid species attacking bees on the parasitism rate of bees, and B) the number of parasitoid species attacking wasps on the parasitism rate of wasps. Other conventions follow Figure 1. 


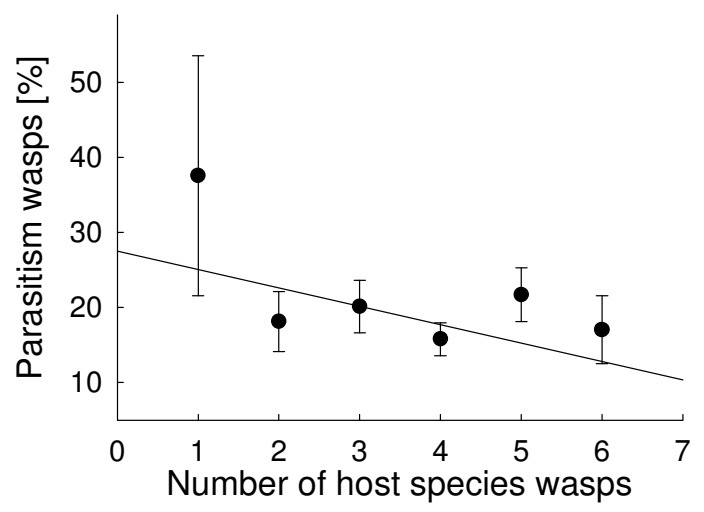

Figure 5:

Effects of the species number of wasps on parasitism rate of wasps. Other conventions follow Figure 1.

\section{Discussion}

Effects of vegetation diversity on cavity-nesting bees and wasps

In our study system, the abundance of cavity-nesting bees and wasps was strongly positively related to floral diversity, which was also related in terms of species richness. Plant species richness themselves did not show any effects on the cavity-nesting community, but strongly increased floral diversity. One explanation might be that our study organism are directly connected with floral diversity (adults of both guilds and larvae of bees feed on pollen and nectar) but only indirectly by plant species richness. Changing plant species richness can mediate changes in e.g. for floral diversity, community biomass, LAI, vegetation height, what in turn also affect arthropod abundance or diversity (Hooper et al. 2005, Balvanera et al. 2006, Marquard et al. submitted).

Interestingly, beside plant species richness, wasps depended also from the surrounding landscape (e.g. low wasp abundance and richness in plots: connected to the street, inside the experimental field site, farthest to the river) in contrast to bees, which were affected solely by changes in plant species richness. These edge effects may be caused by source populations outside the experimental study site, shown in previous studies by e.g. Kowalski (2005) and Müller (2006). They found that colonization (e.g. for herbivores, spiders, slugs, myriapods) carries out from the margins of the experimental site, e.g. from source populations at the adjacent meadows indicated by higher species richness and abundances of arthropods at the margins. Presumable wasps are better disperser than bees, what may cause these different responses of bees and wasps with regard to their influencing variables. Differences between bees and wasps were also found in previous studies (Klein et al. 2002, Steffan-Dewenter 2002, Steffan-Dewenter and Leschke 2003). 
Positive effects of plant diversity on insect communities at small habitat scale have been found in several studies (Siemann 1998, Knops et al. 1999, Haddad et al. 2001); however previous studies using cavity-nesting hymenoptera have rarely found effects of plant species richness (Steffan-Dewenter and Leschke 2003, Klein et al. 2004, Albrecht et al. 2007, but: Tscharntke et al. 1998, Shefield et al. 2008), maybe caused by the fact that gradients in plant species richness here are a result of changes in management or land-use intensity. For example, in a study of different managed orchard meadows of Steffan-Dewenter and Leschke (2003) found no effects of plant species richness on species richness and abundance of cavitynesting bees and wasps. However, these changes in plant species richness were mediated by different management of the study sites (abandoned, grazed and mown), which may have opposing effects on habitat quality. For example, abandonment at the one hand may reduces flowering herb species, which leads to species decrease of bees, but at the other hand entails a higher number of suitable nesting places, which may enhance species richness of cavitynesting hymenoptera (Steffan-Dewenter and Leschke 2003). In our study experiments, we analyzed plant species richness (or floral diversity) per se, having the same nesting availability and food resources (by randomized species composition) over the entire experimental site, which may explain the positive influence of floral diversity on the cavitynesting community.

Many studies describe high species richness of extensive managed grasslands (Kwaiser and Hendrix 2008), and with the 41 cavity-nesting host species found in our study site, we could confirm these findings. Surprisingly high was the number of bee species (22 species), as former studies of cavity-nesting hymenoptera in Europe in other habitat types found lower numbers and more wasp than bee species (Gathmann and Tscharntke 1999, Steffan-Dewenter 2002, Albrecht et al. 2007, Holzschuh et al. submitted). Contrastingly bees were much less abundant than wasps, which may be explained by the mowing event in June. During that period bees are not able to provision their nests with pollen or nectar in cause of the absence of flowering plants.

\section{Effects of host richness and abundance on parasitoids and parasitism}

Parasitoid diversity of both guilds- bees and wasps- was positively related to host species richness (and abundance) and increasing parasitoid diversity lead to higher parasitism rates. Species richness of host species in cavity-nesting communities has been shown to increase species richness of their natural enemies (Tylianakis et al. 2006, Veddeler et al. unpublished 
data), whereas species richness of natural enemies increased parasitism (Klein et al. 2002, Tscharntke et al. 1998, Tylianakis et al. 2006, Veddeler et al. unpublished data). Our results show, that changes on a lower trophic level (host diversity and abundance) can lead to changes at higher trophic level (parasitoid diversity), which can be explained by the high specialization of our parasitoid community and no intra-guild predation. Except the gregarious wasp Melittobia acasta (and two undetermined species, which attacked seven and eight species), which attacked 18 different host species, all other natural enemies consummated one to six host species (see Appendix 1 and 2). Hence a high diverse host community may offer a broader range of resources and attract a higher number of parasitoid species. Our results of a positive relation between parasitoid diversity and parasitism confirm with findings of a diversity-function relationship in multitrophic systems (e.g. Cardinale et al. 2003, Gamfeld et al. 2005, Ives et al. 2005). The main mechanisms which may lead to increased consumption by a more diverse consumer community can be summarized as (1) complementarity effect, (2) facilitation effect, and (3) sampling effects (Tylianakis et al 2006).

In contrast to the positive relation between parasitoid diversity and their function, we found antagonistic effects between host diversity and parasitism, and these patterns were robust across the two different host guilds of bees and wasps, despite their different resource use (floral rewards vs. prey). A high diversity of bees or wasps decreased parasitism by their parasitoid communities. Similar results were found in former landscape studies (Tylianakis et al. 2006, Veddeler et al. unpublished data) and in a meta-analysis of consumer-resource experiments (Hillebrand and Cardinale 2005). The mechanisms behind these patterns are speculative. Hillebrand and Cardinale (2005) explained their consistent results by an increased possibility to have unpalatable species in a diverse host community, which reduces the chance of the consumer to find their attractive hosts. Another possibility for interpretation is a positive host interaction, whereas a diverse and dense host community can offer a more effective protection against parasitoids (e.g. by patrol, by confusing) (Goodell 2003). Our results indicate, that the ecosystem services can be influenced by different trophic levels as here by the host community (bottom- up control) or as shown by the parasitoid community (Hooper et al. 2005).

The exposition of standardized nesting resources within an experimental grassland showed that diverse floral displays attracted higher abundances of pollinators (bees) and predators (wasps), whereas higher abundances as well increased their species richness. The more 
diverse host communities we found with increasing floral diversity attracted a higher number of parasitoid species, which increased their function (parasitism). But contrastingly, increasing host diversity could limit parasitism; hence cavity-nest communities in plant species rich communities might be more resistance against consumption.

In conclusion vegetation diversity changes can derive great effects on mobile insects like cavity-nesting bees and wasps that are strongly flier to collect food for their brood. These impacts in the changes of vegetation diversity to diversity and abundance of cavity nesters can be reflected in further effects of the interactions in the next higher tropic level, the brood parasitism of the flying insects. In context of conservation strategies improvements at small scale (plot scale in a habitat) may result in great improvement of insect diversity, abundance and their associated ecosystem services.

\section{Acknowledgement}

We thank all people helping with the management of the Jena-Experiment, especially Alexandra Weigelt as field coordinator and the gardeners Steffen Eismann, Silke Hengelhaupt, Sylvia Junghans, Ute Köber, Katja Kunze, Gerlinde Kratzsch, Heike Scheffler, and Ulrike Wehmeier. The help during fieldwork by Sylvia Creutzburg, Michaela Knauer and Heike Baldeweg and all the helpers during the weeding campaigns is greatly acknowledged.

The Jena Experiment is funded by the Deutsche Forschungsgemeinschaft, with additional support from the Friedrich Schiller University of Jena and the Max Planck Society.

\section{References:}

Albrecht, M., Duelli, P., Schmid, B. and Muller, C. B. 2007. Interaction diversity within quantified insect food webs in restored and adjacent intensively managed meadows. Journal of Animal Ecology 76: 1015-1025.

Amiet, F., Müller, A. \& Neumeyer, R. 1999. Fauna Helvetica 4: Apidae 2- Colletes, Duforea, Hylaeus, Nomia, Nomioides, Rhopitoides, Rophites, Sphecodes, Systropha. Schweizerische Entomologische Gesellschaft

Bährmann, R. 1995. Bestimmung wirbelloser Tiere. - Gustav Fischer Verlag Jena, Stuttgart.

Balvanera, P., Pfisterer, A. B., Buchmann, N., He, J. S., Nakashizuka, T., Raffaelli, D. and Schmid, B. 2006. Quantifying the evidence for biodiversity effects on ecosystem functioning and services. - Ecology Letters 9: 1146-1156.

Biesmeijer, J. C., Roberts, S. P. M., Reemer, M., Ohlemuller, R., Edwards, M., Peeters, T., Schaffers, A. P., Potts, S. G., Kleukers, R., Thomas, C. D., Settele, J. and Kunin, W. E. 
2006. Parallel declines in pollinators and insect-pollinated plants in Britain and the Netherlands. - Science 313: 351-354.

Cardinale, B.J., Harvey, C.T., Gross, K. \& Ives, A.R. 2003. Biodiversity and biocontrol: emergent impacts of a multi-enemy assemblage on pest suppression and crop yield in an agroecosystem. Ecology Letters 6: 857-865.

Cartar, R. V. 2004. Resource tracking by bumble bees: Responses to plant-level differences in quality. - Ecology 85: 2764-2771.

Crawley, M.J. 2002. Statistical computing. An introduction to data analysis using S-Plus.Wiley, Chichester.

Dollfuss, H. 1991. Bestimmungsschlüssel der Grabwespen Nord- und Zentraleuropas (Hymenoptera, Sphecidae). - Linzer biol. Beitr. 27: 905-1019.

Drenovsky, R. E. and Richards, J. H. 2005. Nitrogen addition increases fecundity in the desert shrub Sarcobatus vermiculatus. - Oecologia 143: 349-356.

Ebeling, A., Klein, A.-M., Schumacher, J., Weisser, W.W. and Tscharntke, T. (submitted). How does plant richness affect pollinator richness and temporal stability of flower visits?

Foley, J. A., DeFries, R., Asner, G. P., Barford, C., Bonan, G., Carpenter, S. R., Chapin, F. S., Coe, M. T., Daily, G. C., Gibbs, H. K., Helkowski, J. H., Holloway, T., Howard, E. A., Kucharik, C. J., Monfreda, C., Patz, J. A., Prentice, I. C., Ramankutty, N. and Snyder, P. K. 2005. Global consequences of land use. - Science 309: 570-574.

Gamfeldt, L., Hillebrand, H. \& Jonsson, P.R. 2005. Species richness changes across two trophic levels simultaneously affect prey and consumer biomass. Ecology Letters 8: 696703.

Gathmann, A. and Tscharntke, T. 1999. Landschafts-Bewertung mit Bienen und Wespen in Nisthilfen: Artenspektrum, Interaktionen und Bestimmungsschl $\square$ ssel. - Naturschutz und Lamdschaftspflege Baden-Württemberg 73: 277-305.

Goodell, K. 2003. Food availability affects Osmia pumila (Hymenoptera : Megachilidae) foraging, reproduction, and brood parasitism. - Oecologia 134: 518-527.

Haddad, N. M., Tilman, D., Haarstad, J., Ritchie, M. and Knops, J. M. H. 2001. Contrasting effects of plant richness and composition on insect communities: A field experiment. American Naturalist 158: 17-35.

Hillebrand, H. \& Cardinale, B.J. 2004. Consumer effects decline with prey diversity. Ecology Letters 7: 192-201.

Holzschuh, A., Steffan-Dewenter, I. and Tscharntke, T. (submitted). Grass strip corridors in agricultural landscapes enhance nest site colonization by solitary wasps. 
Hooper, D.U., Chapin, F.S., Ewel, J.J., Hector, A., Inchausti, P., Lavorel, S., Lawton, J.H., Lodge, D.M., Loreau, M., Naeem, S., Schmid, B., Setälä, H., Symstad, A.J., Vandermeer, J. \& Wardle, D.A. 2005. Effects of biodiversity on ecosystem functioning: a consensus of current knowledge. Ecological Monographs 75: 3-35.

Ives, A.R., Cardinale, B.J. \& Snyder, W.E. 2005. A synthesis of subdisciplines: predator-prey interactions, and biodiversity and ecosystem functioning. Ecology Letters 8: 102-116.

Klein, A.-M., Tscharntke, T., Steffan- Dewenter, I. and Buchori, D. 2002. Effects of Land-use intensity in tropical agroforestry systems on coffee flower-visiting and trap-nesting bees and wasps. - Conservation Biology 16 No.4: 1003-1014.

Klein, A. M., Steffan-Dewenter, I. and Tscharntke, T. 2004. Foraging trip duration and density of megachilid bees, eumenid wasps and pompilid wasps in tropical agroforestry systems. - Journal of Animal Ecology 73: 517-525.

Klein, A. M., Vaissiere, B. E., Cane, J. H., Steffan-Dewenter, I., Cunningham, S. A., Kremen, C. and Tscharntke, T. 2007. Importance of pollinators in changing landscapes for world crops. - Proceedings of the Royal Society B-Biological Sciences 274: 303-313.

Kowalski, E. 2005. Dichtemuster herbivore Konsumentengruppen entlang eines Diversitätsgradienten in einem experimentellen Grasland. - Diploma thesis, Institute of Ecology, University Jena.

Knops, J. M. H., Tilman, D., Haddad, N. M., Naem, S., Mitchell, C. E., Haarstad, J., Ritchie, M. E., Howe, K. M., Reich, P. B., Siemann, E. and Groth, J. 1999. Effects of plant species richness on invasion dynamics, disease outbreaks, insect abundances and diversity. Ecology Letters 2: 286-293.

Kremen, C. 2005. Managing ecosystem services: what do we need to know about their ecology? - Ecology Letters 8: 468-479.

Kunz, P. 1994. Die Goldwespen (Chrysididae) Baden- Württembergs.- Beih. Veröff. Naturschutz Landschaftspfl. Bad.-Württ. 77: 188p.

Kwaiser, K. S. and Hendrix, S. D. 2008. Diversity and abundance of bees (Hymenoptera : Apiformes) in native and ruderal grasslands of agriculturally dominated landscapes. Agriculture Ecosystems \& Environment 124: 200-204.

LaSalle, J. and Gould, I.D. 1993. Hymenoptera: their diversity, and their impact on the diversity of other organisms in: J. LaSalle and Gould, I.D (ed) Hymenoptera and Biodiversity.- CAB International, Wallingford, U.K., pp 1-26.

Linsenmaier, W. 1997. Die Goldwespen der Schweiz. - Veröff. Natur-Museum Luzern, 9: 1139. 
Marquard, E., Weigelt, A., Temperton, V.M., Roscher, C., Schumacher, J., Buchmann, N., Fischer, M., Weisser, W.W. and Schmid, B. (submitted). Plant species richness and functional composition drive overyielding in a 6-year grassland experiment.

Montoya, J. M., Rodriguez, M. A. and Hawkins, B. A. 2003. Food web complexity and higher-level ecosystem services. - Ecology Letters 6: 587-593.

Müller, R. 2006. Einfluss der Artendiversität unterer trophischer Ebenen auf Artendiversität und Dominanzstruktur bodenjagender Araneae: Inasionsmuster in einem experimentellen Rasenökosystem. - Diploma thesis, Institute of Ecology, University Jena.

Perfecto, I., Mas, A., Dietsch, T. and Vandermeer, J. 2003. Conservation of biodiversity in coffee agroecosystems: a tri-taxa comparison in southern Mexico. - Biodiversity and Conservation 12: 1239-1252.

Potts, S. G., Petanidou, T., Roberts, S., O'Toole, C., Hulbert, A. and Willmer, P. 2006. Plantpollinator biodiversity and pollination services in a complex Mediterranean landscape. Biological Conservation 129: 519-529.

Ricketts, T. H., Regetz, J., Steffan-Dewenter, I., Cunningham, S. A., Kremen, C., Bogdanski, A., Gemmill-Herren, B., Greenleaf, S. S., Klein, A. M., Mayfield, M. M., Morandin, L. A., Ochieng, A. and Viana, B. F. 2008. Landscape effects on crop pollination services: are there general patterns? - Ecology Letters 11: 499-515.

Robinson, R. A. and Sutherland, W. J. 2002. Post-war changes in arable farming and biodiversity in Great Britain. - Journal of Applied Ecology 39: 157-176.

Rodríguez, M.A. \& Hawkins, B. 2000. Diversity, function and stability in parasitoid communities. Ecology Letters 3: 35-40.

Roscher, C., Schumacher, J., Baade, J., Wilcke, W., Gleixner, G., Weisser, W. W., Schmid, B. and Schulze, E. D. 2004. The role of biodiversity for element cycling and trophic interactions: an experimental approach in a grassland community. - Basic and Applied Ecology 5: 107-121.

Scheuchl, E. Illustrierte Bestimmungstabellen der Wildbienen Deutschlands und Österreichs (Band 2).

Schmid-Egger, C. 1995. Bestimmungsschlüssel für die deutschen Arten der solitären Faltenwespen (Hymenoptera, Eumeninae). - Deutscher Jugendbund für Naturbeobachtung. Schmid, B., Hector, A., Huston, M.A., Inchausti, P., Nijs, I., Leadley, P.W., Tilman, D. 2002. The design and analysis of biodiversity experiments. In: Inchausti P (ed) Biodiversity and Ecosystem Functioning: Synthesis and Perspectives. Oxford University Press, Oxford, pp 61-75. 
Sheffield, C. S., Kevan, P. G., Westby, S. M. and Smith, R. F. 2008. Diversity of cavitynesting bees (Hymenoptera : Apoidea) within apple orchards and wild habitats in the Annapolis Valley, Nova Scotia, Canada. - Canadian Entomologist 140: 235-249.

Siemann, E. 1998. Experimental tests of effects of plant productivity and diversity on grassland arthropod diversity. - Ecology 79: 2057-2070.

Spaethe, J., Tautz, J. and Chittka, L. 2001. Visual constraints in foraging bumblebees: Flower size and color affect search time and flight behavior. - Proceedings of the National Academy of Sciences of the United States of America 98: 3898-3903.

Steffan-Dewenter, I. 2002. Landscape context affects trap-nesting bees, wasps, and their natural enemies. - Ecological Entomology 27: 631-637.

Steffan-Dewenter, I. and Leschke, K. 2003. Effects of habitat management on vegetation and above-ground nesting bees and wasps of orchard meadows in Central Europe. Biodiversity and Conservation 12: 1953-1968.

Thompson, J. D. 2001. How do visitation patterns vary among pollinators in relation to floral display and floral design in a generalist pollination system? - Oecologia 126: 386-394.

Tscharntke, T., Gathmann, A. and Steffan-Dewenter, I. 1998. Bioindication using trapnesting bees and wasps and their natural enemies: community structure and interactions. Journal of applied ecology 35: 708-719.

Tscharntke, T., Klein, A. M., Kruess, A., Steffan-Dewenter, I. and Thies, C. 2005. Landscape perspectives on agricultural intensification and biodiversity - ecosystem service management. - Ecology Letters 8: 857-874.

Tylianakis, J.M., Tscharntke, T. and Klein, A.-M. 2006. Diversity, ecosystem function, and stability of parasitoid-host interactions across a tropical habitat gradient. - Ecology 87(12): 3047-3057.

Tylianakis, J. M., Tscharntke, T. and Lewis, O. T. 2007. Habitat modification alters the structure of tropical host-parasitoid food webs. - Nature 445: 202-205. 


\section{SUMMARY}

During the past decades a worldwide loss of biodiversity has been identified, and understanding the consequences for biotic interactions and associated ecosystem services has become a major focus. Ecosystem services of substantial importance are for example crop pollination, pest predation or parasitism. The Jena-Experiment, which is based on an experimental manipulation of plant species richness, offers a great opportunity to study the effects of plant diversity per se, because many confounding factors such as management or land-use intensity of descriptive field studies are excluded. We studied invasion success and performance of Centaurea jacea at different plant diversity levels. Further we focused on the effects of plant species richness, on flower visitors, trap-nesting Hymenoptera and plantpollinator networks.

The first part of the thesis describes the impact of plant species richness and plant functional group richness on the survival and performance on the transplanted phytometer species Centaurea jacea in two consecutive years. The survival of transplanted Centaurea jacea into an established plant community decreased with increasing richness of plant species and plant functional groups and in plots, where legume species were present. Dry weight, height and the number of flower heads of the survived plants decreased with increasing plant species richness. Neither plant species richness nor plant functional group richness affected the leaf area eaten by herbivores. In conclusion, the establishment of Centaurea jacea was negatively influenced by increasing plant species richness and legume presence, but after successful establishment plants even profited from the presence of legumes.

The second part of the thesis describes the response of species richness and frequency of pollinators to floral diversity and analyses the temporal stability of pollinator visits with changing number of flowering plant species. In more detail we investigated how floral diversity structures the interactions between plants and their pollinators, holding important information about specialization and effectiveness of pollinator's resource use and sensitivity of mutualistic networks to extinction processes. The results showed that higher floral diversity led to a strong increase of the dynamic stability (lower temporal variability) in the frequency of pollinator visits. Pollinator species richness and the frequency of pollinator visits increased with increasing floral diversity and floral abundance (percent blossom cover). This effect was strong for the frequency of social pollinator visits (honey bees and bumble bees) but differed for solitary bees and species richness of bumble bees. Pollinator richness increased up to a 
blossom cover of only $15 \%$, whereas the frequency of pollinator visits was linearly related to blossom cover up to $30 \%$. These results may indicate that the grasslands were not saturated in pollinator richness. Furthermore, linkage density increased with higher floral resource diversity, suggesting higher ecosystem stability (lower sensitivity) of mutualistic networks against disturbances such as plant diversity loss, and a reduced species extinction probability with higher floral resource diversity. Floral resource specialization of solitary bees increased with increasing floral resource diversity, and honeybees, but not bumblebees, showed the same pattern with marginal significance. Network connectance decreased with floral diversity, possibly indicating an increase in pollinator specialization. In conclusion, grasslands with high numbers of plant species enhance and stabilize flower visitation and increases pollinator's resource specialization. That underlines the need to conserve diverse grasslands for maintenance of pollinator diversity and associated pollination services.

In the last part of the thesis, the impact of plot specific plant species richness on the diversity and density of cavity-nesting bees, wasps, and their natural enemies were investigated. Density of bees and wasps increased with increasing number of flowering plant species. Species richness of bees and wasps and their natural enemies was not directly affected by plant species richness or floral diversity, but brood cell abundance was. With increasing number of brood cells (bees and wasps) we also found higher numbers of species (bees, wasps, and natural enemies). Species richness of natural enemies attacking bees or wasps was positively related to parasitism rate, but species richness of their hosts decreased parasitism rate. In conclusion vegetation diversity changes can derive great effects on mobile insects like cavity-nesting bees and wasps that are strongly flier to collect food for their brood. These impacts in the changes of vegetation diversity to diversity and abundance of cavity nesters can be reflected in further effects of the interactions in the next higher tropic level, the brood parasitism of the flying insects.

The main results of this thesis provide evidence that the diversity of pollinators and trapnesting Hymenoptera as well as the interaction patterns between plants and their pollinators were strongly influenced by plant species. Thanks to the experimental design of this study, the pure effect of plant diversity ("diversity per se") could be analyzed avoiding confounding factors in real world ecosystems. The patterns and processes found enforce previous findings and underline the need to conserve plant-rich ecosystems to encourage insect species 
diversity, and biotic interactions providing key ecosystem services such as pollination, predation, and parasitism. 


\section{DANKSAGUNG}

Ich danke ganz herzlich Prof. Teja Tscharntke für die Ermöglichung der Arbeit, die nur durchgeführt werden konnte, weil er immer von dem Erfolg und der Wichtigkeit des Themas überzeugt war und der während der gesamten Promotionszeit ein hervorragender Betreuer und Unterstützer war.

Bei Prof. Wolfgang W. Weisser möchte ich mich bedanken, für die freundliche Aufnahme in seiner Arbeitsgruppe in Jena und für die Übernahme des Korreferats.

Besonderer Dank gilt Dr. Alexandra-Maria Klein, die mir immer mit Rat und Tat zur Seite stand, auf alle Fragen eine Antwort wusste und auch vor Motivationsarbeit in schwierigen Zeiten nicht halt gemacht hat. Ganz vielen Dank für die produktive und schöne Zusammenarbeit!

Die Arbeit im Rahmen des Jena-Experiments wurde erst durch die hervorragende Arbeit unserer Koordinatoren Dr. Alexandra Weigelt und Dr. Christiane Roscher möglich und natürlich durch die umsetzenden Hände der Gärtner Steffen Eismann, Silke Hengelhaupt, Sylvia Junghans, Ute Köber, Katja Kunze, Gerlinde Kratzsch, Heike Scheffler und Ulrike Wehmeier. Ohne sie und die vielen studentischen Hilfskräfte wäre das Feld wahrscheinlich im Unkraut untergegangen und die Arbeit unmöglich geworden. Des weiteren möchte ich meinen unermüdlichen Helfern während der Feldarbeit danken: Sylvia Creutzburg, Heike Baldeweg, Michaela Knauer und Claudia Heise. Allen Mitgliedern der Forschergruppe Biodiversität sei gedankt für die tolle Zusammenarbeit und die vielen Anregungen und Diskussionen bei den Projekttreffen und besonders den Doktoranden für den vielen Spaß auch bei harter Arbeit und danach.

Christoph und Jason danke ich für die tausend Antworten auf tausend Fragen und Rätsel der Statistik und für die interessanten Diskussionen.

Hella Grabe, Jutta Gilles, Denise Göpfert und Susanne Schiele danke ich für die Arbeit im „Hintergrund“ in ungeliebten Bereichen der Bürokratie und Organisation.

Für die schöne Arbeitsathmosphäre und das gute Raumklima danke ich meinen Zimmergenossinnen Ilka, Sylvia und Gerlinde und der gesamten Arbeitsgruppe des Fachbereichs Multitrophische Interaktionen in Jena für die nette Aufnahme in der Fremde und die schöne Zeit, die ich dort verbracht habe. 
Tausend Dank geht an meine kleine Familie, die mir oft genug meine Grenzen gezeigt hat, aber durch die vielen schönen Momente unglaublich Kraft gegeben hat.

Ich danke meinen Eltern, dass sie mir den Weg zu dieser Abeit geebnet haben, meiner Mutter, dass sie immer in Gedanken bei mir ist und meinem Vater für seine tatkräftige Unterstützung. 


\section{PUBLIKATIONEN}

Ebeling, A., Klein, A.-M. \& Tscharntke, T. (in preparation): Experimental small-scale changes in plant diversity affect nesting bees and wasps and their parasitoids.

Nitschke, N., Ebeling, A., Rottstock, T., Scherber, C., Tscharntke, T., Fischer, M. \& Weisser, W.W. (in preparation): Plant diversity effects on invasiveness, plant fitness and herbivory in the common knapweed, Centaurea jacea.

Rottstock, T., Ebeling, A., Scherber, C., Tscharntke, T., Weisser, W.W. \& Fischer, M. (in preparation): The influence of plant diversity on phytometer performance.

Ebeling, A.; Klein, A.M.; Schumacher, J.; Weisser, W.W. \& Tscharntke, T. (in revision): How does plant richness affect pollinator richness and temporal stability of flower visits?

Ebeling, A.; Klein, A.M.; Müller, C.B. \& Tscharntke, T. (submitted): Plant diversity increases floral specialization in plant-pollinator interaction webs.

Richter, A.; Klein, A.M. \& Tscharntke, T. (2007): Abandoned coffee fields: a refuge of arthropod diversity and natural-enemy populations? Agroforestry systems 69: 175-182

Ebeling, A., Klein, A.-M., Tscharntke, T. (2007): Plant-pollinator interactions in an experimental grassland. In: Proceedings of the GFÖ; Abstracts of the $37^{\text {th }}$ Annual Conference of the Ecological Society, Marburg, p.96

Richter, A., Klein, A.-M., Weisser, W.W., Tscharntke, T. (2006): Pollinator diversity and plant-pollinator interactions in a gradient of plant species diversity. In: Proceedings of the GFÖ; Abstracts of the $36^{\text {th }}$ Annual Conference of the Ecological Society, Bremen, p.60.

Richter, A.; Klein, A.M. \& Tscharntke, T. (2005): Abandoned coffee fields as a refuge of arthropod diversity and natural-enemy populations. In: Tropical ecosystems: functional biodiversity \& human influence; Abstracts of the 18th Annual Conference of the Society for Tropical Ecology, Humboldt- University Berlin, p.111.

Richter, A.; Klein, A.M. \& Tscharntke, T. (2004): Coffee berry borer infestation increased with increasing proportion of overripe berries in agroforestry. In: Biodiversity and dynamics in tropical ecosystems; Abstracts of the 17th Annual Conference of the Society for Tropical Ecology, University of Bayreuth (ISSN 0944-4122), p.224. 


\section{CURRICULUM VITAE}

\section{Anne Ebeling}

geboren 13.10.1977 in Cottbus

Seit 2005

2003-2004

1998-2003

1997
Promotion am Fachgebiet Agrarökologie der Georg-August

Universität Göttingen im Rahmen des DFG Projekts Jena-Experiment unter Betreuung von Prof. Dr. Teja Tscharntke und Dr. AlexandraMaria Klein

Diplomarbeit zum Thema: ,Vergleich der Arthropodenlebensgemeinschaften von Coffea arabica L. (1753) in Agroforstsystemen und Kaffeebrachen Ecuadors“am Fachgebiet Agrarökologie der Georg-August Universität Göttingen im Rahmen des Projektes BIOSYS ("Evaluation of biological diversity of land-use systems in mega-diverse regions of costal Ecuador") unter Betreuung von Prof. Dr. Teja Tscharntke, Prof. Dr. Ragnar Kinzelbach und Dr. AlexandraMaria Klein

Studium der Biologie and der Universität Rostock; Fächer Zoologie, Entomologie und Meeresbiologie

Abitur am Heinrich-Heine Gymnasium in Cottbus 